\title{
BIOLOGICAL (MOLECULAR AND CELLULAR) MARKERS OF TOXICITY
}

\section{FINAL REPORT}

ORNL/M-1845

December 15, 1991

Lee R. Shugart

Stephen J. D'Sumey

Christine Gettys-Hull

M. S. Greeley, Jr.

Oak Ridge National Laboratory

Oak Ridge, Tennessee 37831-6036

Supported by

U.S. ARMY MEDICAL RESEARCH AND

DEVELOPMENT COMMAND

Fort Detrick, Frederick, MD 21.702-5012

Army Project Order No. 88PP8861

Contracting Officer's Representative

H.S. Gardner

Health Effects Research Division

U.S. ARMY BIOMEDICAL

RESEARCH AND DEVELOPMENT LABORATORY

Fort Detrick, Frederick, MD 21702-5010

Approved for public release

distribution unlimited

The findings of this report are not to be construed as an official Department of the Army

position unless so designated by other authorized do:uments. 


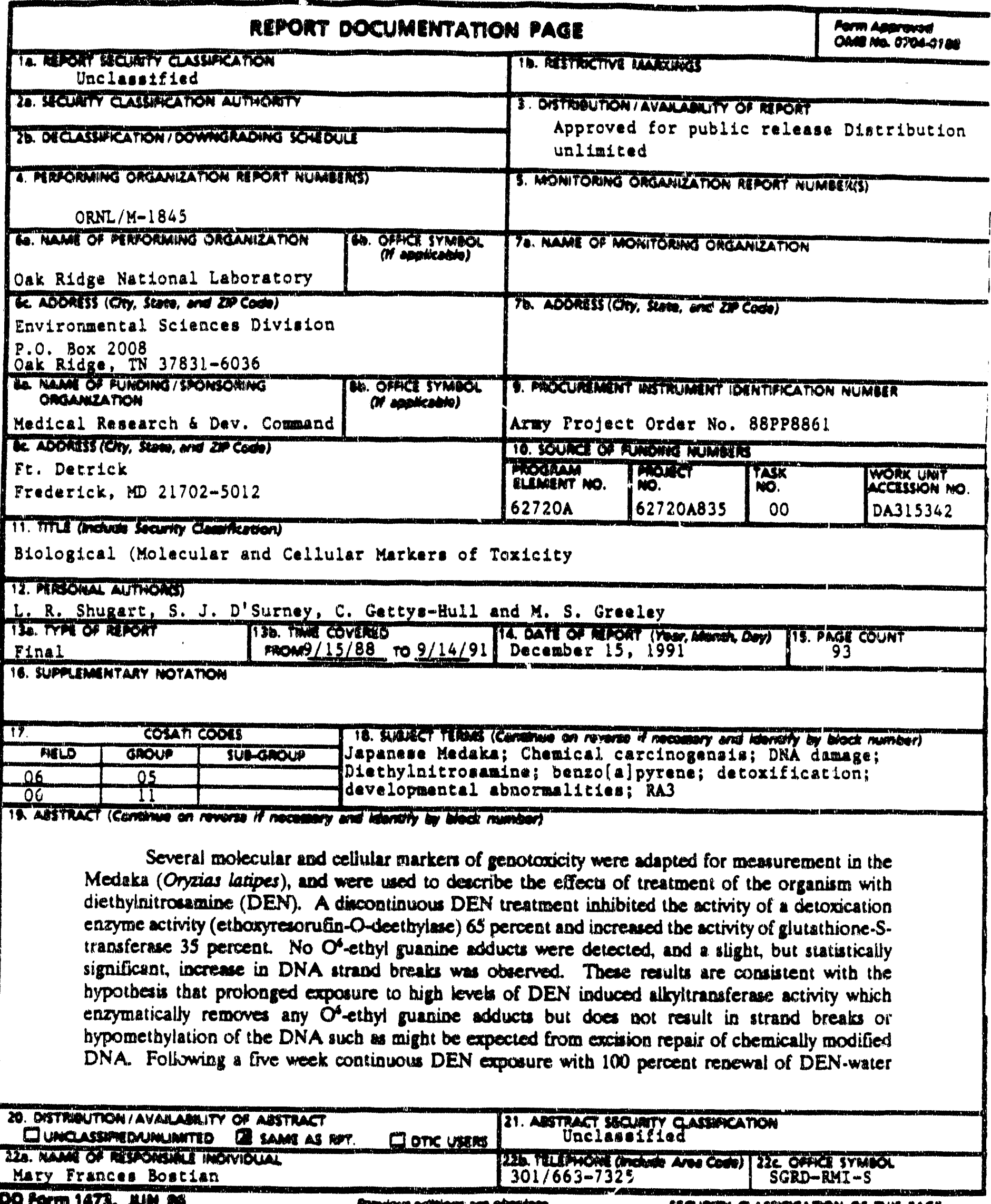


Iten 19.

ABSTRACT (continued)

every third day, the $F$ values (DNA double strandedness) increased considerably and to a similar extent in fish exposed to 25, 50, and $100 \mathrm{ppm}$ DEN. This thas been observed also in medaka exposed to BaP. Flow cytometric analysis of DEN exposed liver tissue showed that cell killing and stimulation of replacement cell production occurred during exposure. An increased rate of cell division and fixation of DEN induced mutation may be an important early component of liver carcinogenesis.

Following a series of exposures to BaP (1 $\mu / \mathrm{L})$, there was an increase in fecundity and in the number of ovarian vitellogenic oocytes. Following an additional series of BaP (4 $\mu g / \mathcal{L}$ ) exposure studies conducted on the Japanese medaka, adducts were detected after exposure of $\mathbf{4 2}$ hours, but none were detected after 10 day exposure. Strand breals were detected after 10 days, but not after 42 hours. In conducting strand break studies, it was observed that Medaka DNA resisted unwinding from alkalinity and heat, leading to studies investigating this phenomenon. Exposure to BaP in water was conducted for 51 days, at a concentration of $4 \mu \mathrm{K} / \mathrm{L}$. From blood samples of control and exposed Medaka, along with control Bluegill, nuclear chromatin was isolated, and chromosomal/nuclear proteins were studied by SDS polyacrylamide gel electrophoresis. Major differences were observed in the histone fractions between Medaka and Bluegill extracted with $\mathrm{NaCl}$, and between exposed and control Medaka, this may account for resistance of medaka DNA to alkaline unwinding. There was a noticeable decreace in non-histone protein in 51d BaP exposed medaka suggesting that this phenomenon is a consequence of chronic exposure to PAH's and may affect the expression or integrity of the genetic information.

Medaka embryos (Oryzias latipes) were exposed to $10 \mu \mathrm{gL} \mathrm{BaP}$ in embryo rearing medium (ERM) from $4 \mathrm{~h}$ post fertilization through yolk sac absorption. There were no obviously lethal effects observed in the embryos and fry. BaP-treated embryos had significantly more circulatory abnormalities, with $12.14 \% \pm 3.33$ in $48 \mathrm{HBaP}$ embryos and fry. Only $4.55 \% \pm 2.22$ of control embryos were observed with circulatory abnormalities. Developmental abnormalities such as twining, exophthalmic and altered pigmentation occurred in the exposed groups, but were not observed in the controls. BaP-exposed embryon required $48 \mathrm{~h}$ longer for $50 \%$ of the embryos to hatch, and exposed embryos continued to hatch for $192 \mathrm{~h}$ beyond the last successful control batch. 
TORERORO

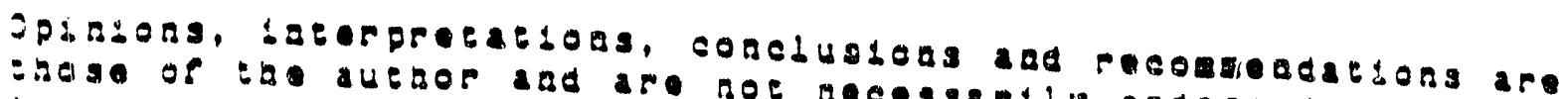
dray.

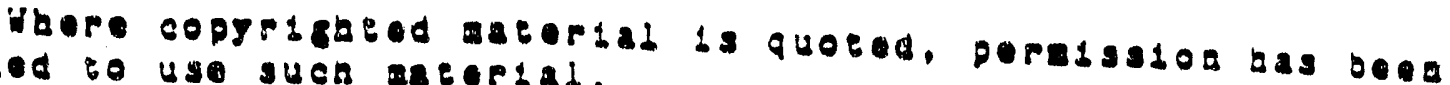

obtalaed to uso juca aceriad.

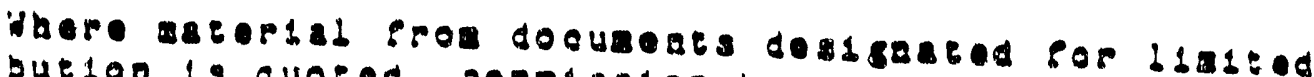

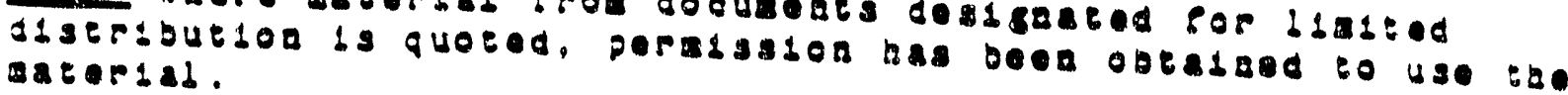

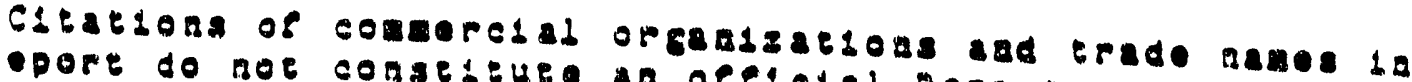

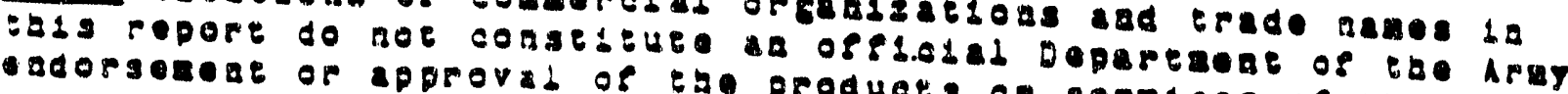
orsandzacions.

289

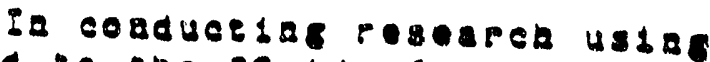

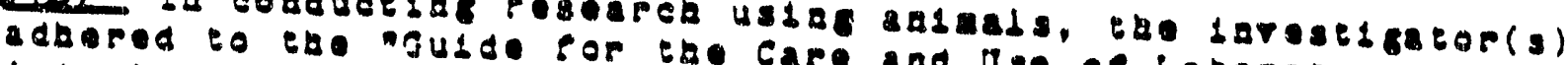

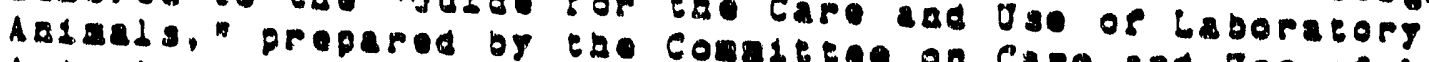

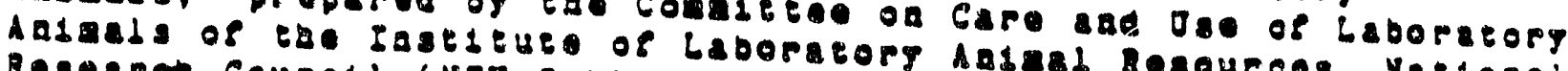

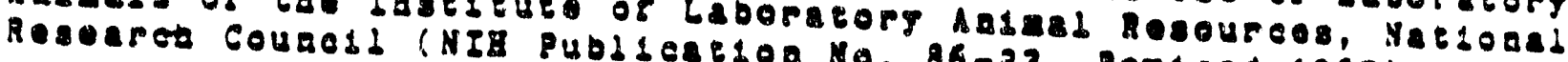

For tbo procection of buad subjoces, tae daroatcacop(s)

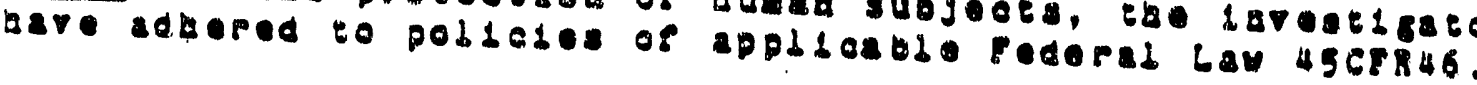

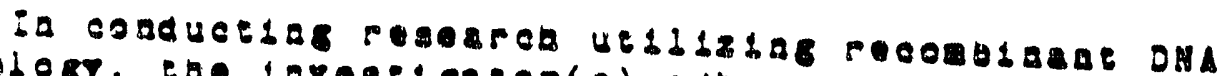

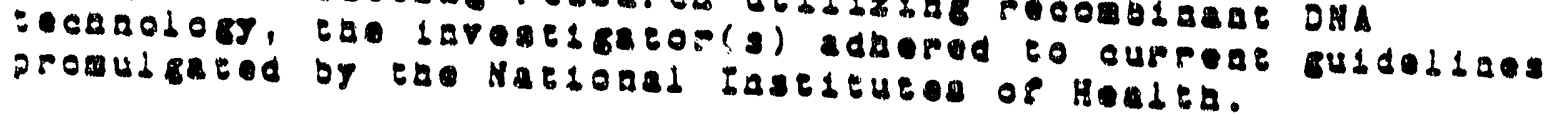

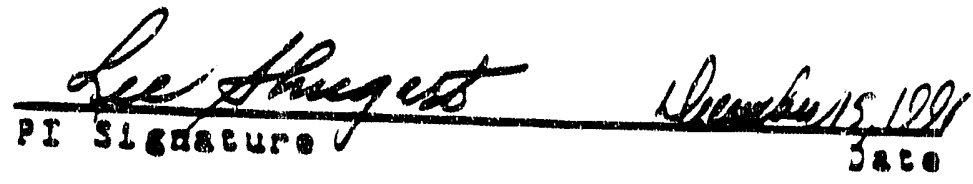


TABLE OF CONTENTS

I. PURPOSE AND SCOPE OF RESEARCH EFFORT $\ldots \ldots \ldots \ldots \ldots \ldots$

1. Objective ....................... 15

2. Rationale ...................... 15

3. Experimental Approach . . . . . . . . . . . . . . . 16

4. References $\ldots \ldots \ldots \ldots \ldots \ldots \ldots \ldots \ldots \ldots \ldots$

II. DNA ALTERATIONS AND ENZYME ACTIVITIES IN JAPANESE MEDAKA (Oryzias latipes) EXPOSED TO DIETHYLNITROSAMINE $\ldots \ldots \ldots \ldots 18$

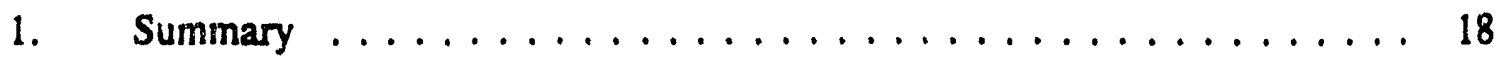

2. Introduction $\ldots \ldots \ldots \ldots \ldots \ldots \ldots \ldots \ldots \ldots \ldots \ldots$

3. Materials and Methods ................... 19

a. Exposure protocols .................... 19

b. DNA integrity .................. 20

c. Detoxication system $\ldots \ldots \ldots \ldots \ldots \ldots \ldots \ldots \ldots$

d. Detoxication Enzymes . . . . . . . . . . . . . . 25

e. Histology . . . . . . . . . . . . . . . 26

4. Results- DEN Exposure $1 \ldots \ldots \ldots \ldots \ldots \ldots \ldots \ldots$

a. DNA Alterations $\ldots \ldots \ldots \ldots \ldots \ldots \ldots \ldots \ldots . \ldots 27$

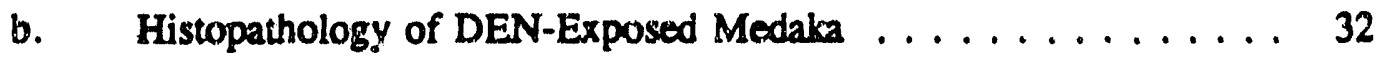

c. Enzyme activity studies . . . . . . . . . . . . . 32

5. Results- DEN Exposure $I I \ldots \ldots \ldots \ldots \ldots \ldots \ldots \ldots \ldots \ldots$

a. DNA strand breaks in 13 week exposure to DEN . . . . . . 37

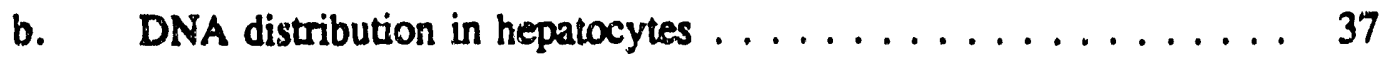

6. Discussion ........................ 38

7. References $\ldots \ldots \ldots \ldots \ldots \ldots \ldots \ldots \ldots \ldots \ldots \ldots$ 
Table of Contents

(continued)

III. MOLECULAR AND CELLULAR MARKERS OF TOXICITY IN THE JAPANESE MEDAKA (Oryzias laripes) EXPOSED TO BENZO[a]PYRENE . . 41

1. Summary $\ldots \ldots \ldots \ldots \ldots \ldots \ldots \ldots \ldots \ldots$

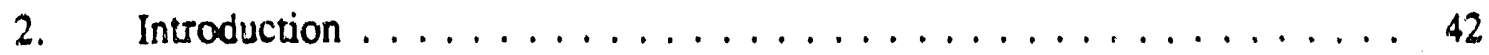

3. Materials and Methods . . . . . . . . . . . . . . . . . 44

a. Uptake and Accumulation of Radiolabeled BaP . . . . . . . . . 44

b. BaP Exposure Experiment I-Reproductive and genotoxic Assessment . . . . . . . . . . . . . . . . 45

c. BaP 7 Day Exposure Experiment II- DNA Damage assessment . . 46

d. Bap 10 Day Exposure Experiment III- DNA Damage Studies . . . 47

e. $\quad 51$ Day BaP Exposure IV-Chromatin analysis $\ldots \ldots \ldots 8$

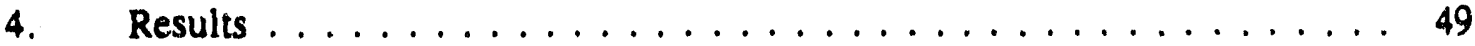

a. Uptake and Accumulation of Radiolabeled BaP . . . . . . . . . 49

b. Bap Exposure Experiment I . . . . . . . . . . . . . . . . . . 49

c. BaP Exposure Experiment II . . . . . . . . . . . . . 53

d. BaP Exposure Experiment III ............... 56

e. BaP Exposure IV . . . . . . . . . . . . . . . . . 59

5. Discussion ......................... 61

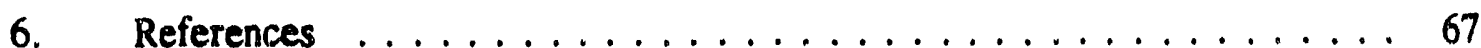

IV. JAPANESE MEDAKA EMBRYO ASSAY FOR DEVELOPMENTAL TOXICITY: ABNORMALITTES OBSERVED AFTER EXPOSURE TO

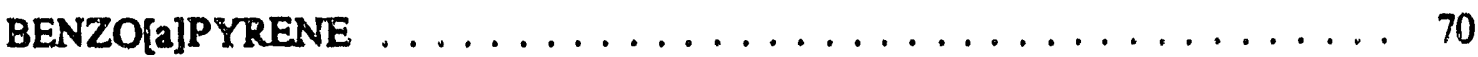

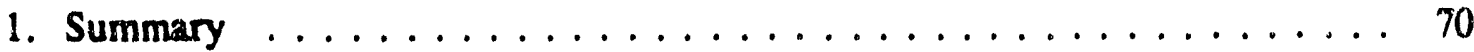

2. Introduction ....................... 70

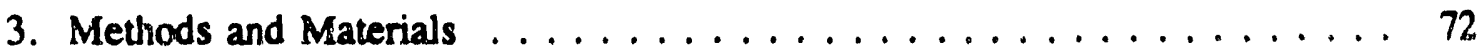

a. Adult Care and Maintenance ................ 72

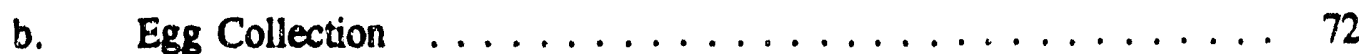




\section{Table of Contents}

(continued)

c. Exposure to BaP $\ldots \ldots \ldots \ldots \ldots \ldots$

d. Preparation of Exposure Solutions . . . . . . . . . . . . . 73

e. Statistics ........................ 74

4. Results ............................... 75

a. Abnormalities in embryo and fry ............. 75

b. Mortality and hatching success and swimbladder inflation ..... 76

5. Discussion ......................... 78

6. References ........................... 79

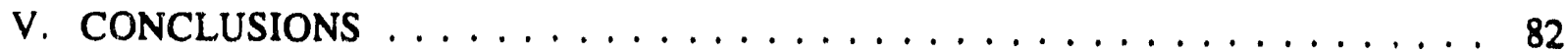

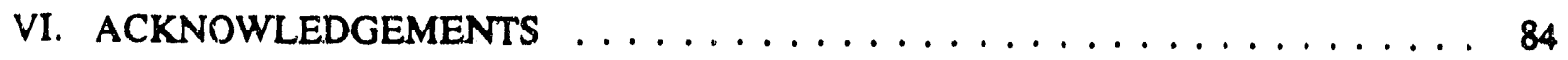




\section{LIST OF FIGURES}

Figure II.1 Frequency histograms of DNA content in hepatocytes . . . . . . . . . 31

Figure III. 1 BaP concentration in water during exposure of medaka to $\left[{ }^{14} \mathrm{C}\right]-\mathrm{BaP}$ for 8 days ............................ 50

Figure III.2 BaP accumulation in medaka: Accumulation of $\mathrm{BaP}$ in $\left[{ }^{14} \mathrm{C}\right]$ equivalents $(\mu \mathrm{g} / \mathrm{Kg})$ in whole body tissues of adult medaka over time . . 50

Figure III.3 Accumulation of BaP in male vs. female medaka . . . . . . . . . 51

Figure III.4 $F$ values for DNA of medaka exposed to BaP in "exposure $I^{n} \ldots \ldots$

Figure III.5 $F$ values for DNA medaka exposed to BaP in "exposure II" . . . . . . 54

Figure III.6 Thermal denaturation of BaP treated medaka DNA under alkaline conditions .......................... 55

Figure III.7 Comparison of alkaline unwinding of medaka DNA from control, BaP $(4 \mu \mathrm{g} / \mathrm{L})$ and verapamil $(1 \mu \mathrm{g})$ exposed fish $\ldots \ldots \ldots 56$

Figure III.8 Comparison of alkaline unwinding $F$ values from medaka exposed to a constant BaP concentration of $4 \mu \mathrm{g} / \mathrm{L}$ for 42 hours BaP exposure . . . . 57

Figure III.9 BaP-tetrol adducts in medaka DNA exposed to a constant concentration of BaP of $4 \mu \mathrm{g} / \mathrm{L}$ for 42 hours. Adducts were determined by HPLC fluorescence analysis of tetrols liberated from DNA by acid Hydrolysis. . 57

Figure III.10 $F$ values of medaka DNA after exposure to BaP at a constant concentration of $4 \mu \mathrm{g} / \mathrm{L}$ for 10 days. DNA was purified by a modified procedure which extensively deproteinated the DNA during

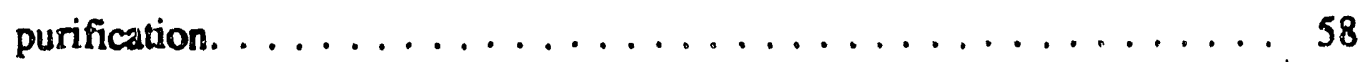

Figure III.11 BaP-tetrol adducts in medaka DNA exposed to BaP for 10 days at a constant concentration of $4 \mu \mathrm{g} / \mathrm{L} \ldots \ldots \ldots \ldots$

Figure III.12 Scanning densitometric profiles of completely dissociated bluegill and medaka chromosomal proteins $\ldots \ldots \ldots \ldots$

Figure III.13 Scanning densitometric profiles of partially dissociate bluegill and medaka nuclear proteins . . . . . . . . . . . . . . . 62

Figure IV. 1 Embryo hatching . . . . . . . . . . . . . . . . . 77 


\section{LIST OF TABLES}

TABLE II.1 Response of Molecular Marker in the Japanese Medaka (nryzias laripes) From Diethylnitrosoamine Exposure I . . . . . . . . . . . . . 28

TABLE II.2 Optimum Conditions For Various Enzyme Activities . . . . . . . . . . . 34

TABLE II.3 Michaelis Constant for EROD activities in various species" . . . . . . . 35

TABLE II.4 EROD Purification and Recovery $\ldots \ldots \ldots \ldots \ldots$

TABLE III.1 Medaka Reproduction . . . . . . . . . . . . . . . . . 51

TABLE III.2 Medaka Development . . . . . . . . . . . . . . . . . . . 52

TABLE IV. 1 Hatching success and mortality in the two groups of embryos. . . . . . 75

TABLE IV.2 Time at which $50 \%$ of the embryos within each group hatched. . . . . 77 


\section{PURPOSE AND SCDPE OF KESEARCH EFFORT}

\section{Objective}

The overall objective of this study was to evaluate the use of the small aquarium fish, Japanese Medaka (Oryzias laripes), as a precictor of potential genotoxicity following exposure to carcinogens. This was accomplished by quantitatively investigating the early molecular events associated with genotoxicity of various tissues of Medaka subsequent to exposure of the organism to several known carcinogens, such as diethyinitrosamine (DEN) and benzo[a]pyrene (BaP).

\section{Rationale}

The Japanese Medaka has recently been used as a bioassay model to screen for carcinogenic compounds in water. The primary endpoint for most small fish carcinogenesis studies is the histopathogenic identification of a neoplastic lesion. Such lesions occur mainly in the liver, although other tissues in which lesiors have been observed include nervous tissue, kidney, mesenchymal tissue, skeletal and smooth muscle. The histogenesis of liver neoplasms in fish is similar to that in rodents. Following exposure to chemical carcinogens, preneoplastic lesions appear as eosinophilic foci, basophilic foci, followed by tumor formation (Hawkins ef al., 1988). This is identical to the process that appears to occur in rodents and other mammals (Farter, 1987).

Therefore, if we are to understand in any depth the processes by which environmental chemicals exhibit genotoxicity, new and innovative techniques will be needed that elucidate the fundamental cellular nature of the various steps subsequent to exposure to these agents. Because of the often long latent period between initial contact with certain chemical and physical agents in our environment and subsexuent expression of deleterious health or ecological impact, the development of sensitive methods for detecting and estimating early exposure is needed so that necessary interventions can ensue. A promising biological endpoint for detecting early exposure to damaging chemicals is the interaction of these 
compounds with cellular macromolecules such as Deoxyribonucleic Acids (DNA). This biological endpoint assumes significance because it can be one of the critical early events leading eventually to adverse effeces (neoplasia) in the exposed organism.

\section{Experimental Approach}

The research program proceeded along several interrelared lines of investigation:

Task 1. Protocols for the exposure of Medaka under controlled laboratory conditions to DEN, and BaP were developed and the effects these chemical carcinogens had on the suite of selected molecular markers were investigated. Several new biumarker assays were also incorporated during the course of the study;

Task 2. Current analytical techniques and methodologies were $\mathrm{v}$ valuated for their effectiveness to detect and quantitate biological responses at the molecular level to the action of genotoxic agents. Particular emphasis was placed on the adaptation of these methods for the detection of enzyme activities associated with detoxication and damaging events that occur to the DNA in liver tissue;

Task 3. The short-term responses of the molecular markers as suitable biomarkers to estimate exposure and predict cellular effects to genotoxic chemicals were evaluated.

A number of biological endpoints were evaluated to measure binmarkers of toxicity in an organism and to determine the degree of expoiure the organism had to xenobiotic compounds. Biological markers can be used to measure both the short-and long-term effects of exposure to toxic substances (Shugart et al., 1991). Early exposure to xenobiotic compounds may be detected via the interaction of such compounds with cellular macromolecules such as DNA, RNA and proteins (Kurelec and Pivcevic 1989), changes in the activities and levels of detoxication enzymes, the induction of mutations or repair of damaged DNA. Changes in DNA sequence can lead to both heritable mutations and carcinogenesis. The interactions of xenobiotics with cellular macromolesules can perturb metabolism and result in cytotoxic effects. Longer-term responses to toxic substances can be evaluated by studying neoplastic transformation, developmental (teratogenic) abnormalities, survivability, fecundity, immunocompetence or pathology. This report will describe three 
separate but related studies to investigate molecular biomarker responses to genotoxic compounds. Section two and three will cover the effects of DEN and BaP exposure on DNA and detoxication enzymes of medaka liver tissue, section four will report on the teratogenic effects of BaP exposure on developing medaka embryos and fry.

The work proposed here focuses on the more fundamental aspects of the problems that deal with the detection of exposure to genotoxic agents through the appropriate use of molecular markers and the potential to predict subsequent adverse effects. Many chemical carcinogens and mutagens have the capacity to cause various types of DNA damage as a result of the interaction of highly reactive metabolites with DNA. Such interactions can form stable adducts with DNA, adducts which result in the formation of alkali-labile apurinic sites, and unstable adducts which cause strand breaks (Harvey, 1982). Indirectly, the fidelity of post replicative modification of DNA (such as minor nucleotide composition) can be affected by genotoxic agents (Shugart, 1990). Each type of damage to the integrity of the DNA, if left uncorrected, could trigger a sequence of events that culminates in the appearance of an overt madignancy. Estimates of these various types of damage to DR/A, along with an appraisal of the organisms capability to maintain the integrity of it's DNA (repair and chromosomal structure-function), will provide the basis for determining bioavailability of the genotoxic agent and for estimating exposure. In addition the information may be used as a short-term predictor of the potential for long-term deleterious effects.

\section{References}

Farber, E. (1987). Possible etiologic mechanisms in chemical carcinogenesis. Environ. Health Perspec. 75:65-70.

Harvey, R. C. (1982). Polycyclic hydrocarbons and cancer. American Sci. 70:386-393.

Hawkins, W. E., Overstreet, R. M. and Lytle, T. F. (1988). Carcinogenicity tests with small fish species. Agyatic Toxicology 11:113-128.

KLielec, B. and Pivcevic, B. (1989). Distinct glutathione-dependentenzyme activities and a verapamil sensitive binding of xenobiotics in a fresh water mussel Anodonta cynnea. Biochem. Bes. Comm. 163:934-940. 
Shugart, L. R., Jimenez, B. D. and McCarthy, J. F. (1991). DNA damage as a óiological marker in aquatic organisms. In: Eleventh Intermational Symposium on Polynuclear Aromatic Hydrocartons: Measurements. Means, and Metabolism, K. Loening, J. Merritt, and M. Conk, Eds., Battelle Press, Columbus, OH, pp. 839-846.

Shugart, L. R. (1990). 5-Methyl deoxycytidine content of DNA from bluegill sunfish exposed to benz[a]pyrene. Environ. Toxicol, and Chem, 9:205-208.

\section{DNA ALTERATIONS AND ENZYME ACTIVITIES IN JAPANESE MEDAKA (Oryzias latipes) EXPOSED TO DIETHYLNITROSAMINE}

\section{Summary}

Several molecular and biochemical markers of genotoxicity wete adapted for measurement in the Medaka, and were used to describe the effects of treatment of the organism with diethylnitrosamine (DEN). DEN treatment inhibited the activity of a detoxication enzyme activity (ethoxyresorufin-O-deethylase; picomoles resorufin/mg protein; control-8.20 \pm 3.76 (Mean $\pm S E M$ ), DEN exposed-2.7 \pm 1.2 ; Students " $t$ " Test, alpha > $0.05<0.001)$ and increased the activity of glutathione-S-transferase; Units/mg protein, control-534 \pm 88 , DEN exposed-724 \pm 213 ; Students " $t$ " Test, alpha $>0.01<0.05$. This pattem of response has been described in preneoplastic rodent cells. No $O^{6}$-ethyl guanine adducts were detected, and a slight, but significant (students " $t$ " test), increase in DNA strand breaks ( $F$ values; control-0.4 \pm 0.04 , DEN exposed-0.2 \pm 0.1 ; students " $t$ " test, alpha $>0.001$ ) was observed. These results are consistent with the hypothesis that prolonged exposure to high levels of DEN induced alkyltransferase activity which enzymatically removes any O6-ethyl guanine adducts but does not result in strand breaks or hypomethylation of the DNA such as might be expected from excision repair of chemically modified DNA. Following a five week continuous exposure to 25,50 , and $100 \mathrm{ppm}$ DEN, the $F$ values (DNA double strandedness) increased considerably and to a similar extent in medaka exposed to three different DEN concentrations (control- $F=.47 \pm .045 \mathrm{DEN}$ exposed- $F=.69 \pm .049 ;$ ANOVA, $f=0.68$, alpha $<0.01$ ). This has been observed also 
in medaka exposed to BaP $(4 \mu \mathrm{g} / \mathrm{L})$. Flow cytometric analysis of DEN exposed liver tissue showed that cell killing and stimulation of replacement cell production occurred during exposure. An increased rate of cell division and fixation of DEN induced mutation may be an important early component of liver carcinogenesis.

\section{Introduction}

This research was undertaken as a preliminary investigation of a more detailed study to evaluate the suitability of the Japanese medaka (Oryzias latipes) as a model organism for predicting genotoxic effects caused by exposure to environmental contaminants.

Fundamental understanding of the molecular and biochemical events that occur subsequent to exposure may make it possible to employ these responses as biomarkers that can be used to estimate exposure and predict cellular effects of genotoxic chemicals (Wogan and Gorelick, 1985; Shugart, 1990b and 1990c). Thus, it may be possible to determine if chemical or waste effluent poses a health threat based on exposure of Medaka to these contaminants. Such a sj'stem would be advantageous because biomarker responses at the molecular level occur more rapidly than histopathological responses. More fundamentally, critical evaluation of the genotoxic process at the molecular and cellular levels in Medaka may provide a foundation for using this convenient and cost-effective animal model for more directly extrapolating to human health effects, based on pharmacodynamic models. Before this approach can be accepted, it is necessary to demonstrate that molecular, biochemical and cellular events associated with genotoxicity are detectable in fish.

\section{Materials and Methods}

\section{a. Exposure protocols}

DEN Exposure 1: Approximately seventy (70) adult medaka (age- 8-10 mo,, weight- 300-500 mg), both sexes, were exposed by the U.S. Army Biomedical Research and Development Laboratory (USABRDL) to a solution of $200 \mathrm{mg} / \mathrm{L}$ of DEN for 24 hours, followed by transfer to clean water for six (6) days. This exposure protocol was repeated 
three additional times for a total of four separate 24 hour exposures to DEN. A control population of seventy (70) fish was similarly treated, but without exposure to DEN. At the end of the exposure, 10 fish from each group were retained by USABRDL for histological evaluation. The remaining animals were sent live, via overnight express (24 hours), to the Oak Ridge National Laboratory (ORNL) and the livers immediately removed and processed for ariaiysis. Fish in the exposed and control groups were pooled in groups of 10 animals (approximately equal numbers of each sex in each replicate). Livers were removed and pooled for evaluation of detoxication enzymes and measurements of DNA alterations (strand breaks and abnormal DNA distribution). The remainder of the animals (termed "carcass") in each replicate were pooled for additional measures of DNA alteration (strand breaks, adducts, ani minor nucleoside composition). The exposure protocol was developed and conducted at USABRDL:

DEN exposure 2: Fourteen hundred (1400) adult medaka (approximately three months old- $60 \%$ female and $40 \%$ males) were acclimated at $25^{\circ} \mathrm{C}$ for two weeks. There were two hundred (200) fish per tank and two tanks per treatment group and one control tank. Three exposure groups contained $100 \mathrm{ppm}, 50 \mathrm{ppm}$, and $25 \mathrm{ppm}$ DEN. Exposures were conducted by Dr. David Hinton at the University of California, Davis for a period of five weeks with $100 \%$ renewel of DEN-water every third day. Samples were taken at one week intervals until termination of exposure at week five, and at 2, 4, and 8 weeks post exposure (eight sampling days total- five exposure and three post exposure). On sampling days, ten (10) fish were taken from each tank, divided into two groups of five tish each. The livers and gills were pooled separately and the remaining carcaises kept apart. Samples were frozen in liquid nitrogen for shipment to the ORNL. Liver samples were analyzed for DNA damage/alterations by flow cytometry (Dr. J. Bickham, Texas A\&M University) and DNA strand break analysis (Dr. L. R. Shugart, ORNL) and for the induction of stress proteins (Dr. Brian Bradley).

\section{b. DNA integrity}

The purpose of the work reported in this section is to evaluate certain measures of DNA integrity as a useful indicator of exposure of the organism to genotoxic 
agents. It is the inability (permanent or transient) of an organism to cope with DNA damage and to maintain DNA integrity that provides the investigator the opportunity to test for genotoxicity. Covalent modification of DNA (adduct formation), strand breakage, and minor nucleoside composition are three measures of DNA integrity being investigated. Since alteration of the DNA is understood to be the initiating event in carcinogenesis, the effect of DEN on several types of DNA damage are being evaluated in the Medaka, including early events such as adduct formation and secondary modifications of DNA integrity, as well as later, generally irreversible effects such as cytogenetic aberrations.

(1) DNA adduct formation. It is anticipated that the DNA of the Japanese Medaka exposed to carcinogenic amounts of DEN will experience damage, especially since DEN is a potent ethylating agent. Analysis for $O^{6}$ ethyl adducts in liver DNA was by a noncompetitive solid phase immunoassay (Adamkiewics et al., 1985).

(2) DNA strand breaks. Another potential source of damage to DNA subsequent to exposure to DEN is strand breakage. Alkaline unwinding is a sensitive analytical technique which has previously been used in cells in culture to detect and quantify DNA strand breaks induced by physical and chemical carcinogens (Daniel et al., 1985). To assess the level of strand breaks of DNA in Medaka, existing methods were modified to allow for the isolation of intact, highly polymerized DNA and the subsequent estimation of strand breaks. Medaka currently on hand in the laboratory were used to verify the protocols listed below.

DNA isolation was accomplished by homogenizing the intact Medaka in $1 \mathrm{~N}$ $\mathrm{NH}_{4} \mathrm{OH} / 0.2 \%$ Triton $\mathrm{X}-100$. The DNA was further purified by differential extraction with chloroform/isoamyl alcohol/phenol (24/1/25-v/v), and passage through a molecular sieve column (Sephadex G50).

DNA strand breaks were measured in the isolated DNA by an alkaline unwinding assay as modified by Shugart, 1988. The technique is based on the time-dependent partial alkaline unwinding of DNA followed by determination of the duplex:total DNA ratio ( $F$ value). Since DNA unwinding takes place at single-strand breaks within the molecule, the amount of double-stranded DNA remaining after a given period of alkaline unwinding will be inversely proportional to the number of strand breaks present at the initiation of the alkaline exposure, provided renaturation is prevented. The amounts of these two types of DNA are 
quantified by measuring the fluorescence that results with bisbenzimidazole - Hoechst dye $\$ 33258$.

This procedure has been further modified to accommodate the isolation and detection of strand breaks in the DNA from a single Medaka liver.

Rydberg, (1975) has established the theoretical background for estimating strand breaks in DNA by alkaline unwinding, which is summarized by the equation:

$$
\ln F=-(\mathrm{K} / \mathrm{M})\left(\mathfrak{l}^{\mathfrak{b}}\right)
$$

where $\mathrm{K}$ is a constant, $t$ is time, $M$ is the number average molecular weight between two breaks, and $\mathrm{b}$ is a constant less than 1 which is influenced by the conditions for alkaline unwinding.

Once DEN-exposed fish are in hand the relative number of strand breaks ( $N$ value) in DNA of medaka from an exposed population can be compared to those from a control population as follows:

$$
N=\left(\ln F_{\mathrm{s}} / \ln F_{\mathrm{r}}\right)-1
$$

where $F$, and $F_{\mathrm{r}}$ are the mean $F$ values of DNA from the exposed and control populations respectively. $N$ values greater than zero indicate that DNA from the exposed population has more strand breaks than DNA from the control population; an $N$ value of 5 , for example, indicates five times more strand breakage.

(3) ${ }^{5} \mathrm{~m}-\mathrm{dCyd}$ content of DNA. ' $\mathrm{m}$-dCyd content of DNA - Deoxyribonucleoside analysis was performed on DNA isolated from one intact Medaka (Shugart, 1990a). To approximately 25 ug of DNA in buffer is added 10 ug each of pancreatic DNase, snake venom phosphodiesterase and bacterial alkaline phosphatase. The contents are mixed, and incubated at $37^{\circ} \mathrm{C}$ for one hour. The mixture is injected onto a $0.6 \times 45 \mathrm{~cm}$ glass column packed with the cation exchanger Aminex A-6 (Bio-Rad Labs, Richmond, CA) equilibrated with $0.45 \mathrm{M}$ ammonium formate, $\mathrm{pH} 4.5$. The column is maintained at a constant temperature of $50^{\circ} \mathrm{C}$ and the sample is eluted isocratically in the same buffer at a flow rate of $1.0 \mathrm{ml} / \mathrm{min}$. The column eluent is monitored by an absorbance detector at $260 \mathrm{~nm}$ and the chromatographic data recorded. 
(4) Abnormal DNA Distribution of Hepatocytes (Flow Cytometry). This work was conducted in collaboration with Dr. Joseph E. Fuhr, Memorial Research Hospital, University of Tennessee, Knoxville, Tennessee and Dr. John Bickham, Texas A\&M University.

Liver tissue is prepared for flow cytometric analysis according to the procedure of McBee and Bickham (1987). DNA histograms indicating the frequency of DNA distribution within the hepatocytes are recorded for each preparation.

\section{c. Detoxication system}

(1) Introduction. Two phases of metabolism are recognized and enzymes representative of both phases have been examined in this research. In Phase I metabolism, catalyzed by the mixed function oxidase (MFO) enzyme system, a reactive functional group (such as - $\mathrm{OH}$ ) is inserted in the parent compound. This enhances the water solubility, and hence excretability, of the substrate; moreover, these activities provide suitable substrates for Phase II conjugating enzymes described below. MFO-mediated reactions are considered important detoxication pathways. However, in a number of instances including key environmental contaminants, this pathway serves to activate substrates to more reactive, toxic products. For example, procarcinogens are metabolized to DNA-reactive carcinogens via MFO activities. Phase II enzymes catalyze the conjugation of highly polar endogenous compounds (generally based upon glucose, amino acids or sulfate) onto suitable substrates, such as Phase I metabolites of lipophilic contaminants. The reactions comprising Phase II metabolism serve to detoxify carcinogens via greatly enhanced excretability of the products. The enzyme receiving attention in this study is the glutathione S-transferase (GST) that catalyze conjugations with reduced glutathione (GSH).

Aquatic organisms living in polluted environments are constantly being exposed to a wide variety of anthropogenic compounds, many of which are of organic nature. As a response to the incorporation of many organic chemicals in tissues, organisms will induce a family of enzymes better known as the Mixed-Function Oxidase (MFO) Systeni or Cytochromes $P-450$. These enzymes aid in the elimination of xenobiotic chemicals by increasing the polarity of these compounds so they can be excreted through the bile and kidney. 
An enzyme representative of the MFO system is 7-ethoxyresorufin O-deethylase (EROD). This enzyme has been shown to be induced in fish livers by polycyclic hydrocarbon such as benzo[a]pyrene and is presently being employed as a biological indicator of pollution at the Oak Ridge National Laboratory (ORNL) in their Biomonitoring Program (Jimenez and Burtis 1989).

Another group of enzymes involved in the detoxication process in fish are the conjugation enzymes. These enzymes are known to add polar groups (such as glutathione, sulfates and glucuronic acids) to organic molecules which aid in their removal from organ tissues. Conjugation with glutathione does not always lead to detoxication of xenobiotic compounds, but may cause bioactivation of a compound (for example, 1,2-dibromoethane) leading to the formation of DNA adducts (Stegeman and Kloeppa-Sams, 1987). We are particularly interested in the effects of organic pollutants on the glutathione S-transferase (GST) enzyme since elevated levels of this enzyme system have been found in organisms exposed to hepatotoxic agents [Oikari and Jimenez unpublished data], and are shown to be induced by other organic pollutants. For example, fish injected intraperitoneally with 3methylcholanthrene (George and Young, 1986) or benzo[a]pyrene (Fain, 1986) produce a significant increase in GST activity.

The two enzyme activities previously mentioned have been shown to be useful indicators of organic pollution in many fish species. However, in small fish (guppies, fathead minnows and Japanese (nedaka) these enzyme analyses are very difficult to perform due to the limited amount of tissue obtained from these small organisms. We have developed a methodology to examine the activity of both these enzymes in medaka by pooling the livers of 12 medaka fish. The MFO activity (EROD) in liver homogenates as well as in hepatic microsomes has been optimized for this species.

(2) Methodology. Japanese Medaka were obtained from the Environmental Protection Agency at Gulf Breeze, Florida and Duluth, Minnesota. They were kept in 15 gallon aquaria under flow-through conditions at $25^{\circ} \mathrm{C}$. All fish were grouped according to their sex. Groups of 20 to 40 male or female adult fish were sacrificed by cervical dislocation and their livers removed without bursting the gallbladder. Livers of fish from the same sex were pooled, weighed and homogenized in Sucrose $0.25 \mathrm{M}, 0.1 \mathrm{M}$ Tris buffer at $\mathrm{pH} 7.4$. 
Homogenates were centrifuged twice and microsomes obtained by differential centrifugation at $106,000 \times \mathrm{g}$ for $2 \mathrm{hrs}$. Microsomes and cytosolic supernatants were stored at $-120^{\circ} \mathrm{C}$ until used for the enzyme activity assays.

\section{d. Detoxication Enzymes \\ (1) Phase LActivity (Ethoxyresorufin-O-deethylase, EROD)}

Livers of fish were pooled, weighed and homogenized in sucrose $0.25 \mathrm{M}, 0.1 \mathrm{M}$ Tris buffer at pH 7.4. Homogenates were centrifuged twice and microsomes obtained by differential centrifugation at $106,000 \times \mathrm{g}$ for $2 \mathrm{hrs}$. Microsomes and cyrtosolic supernatants were stored at $-120^{\circ} \mathrm{C}$ until used for the enzyme activity assays.

The activity of 7-ethoxyresorufin O-deethylase (EROD) from the low speed supernatant of the liver homogenate and from the purified hepatic microsomes were measured fluorometrically at $30^{\circ} \mathrm{C}$ (Burke and Mayer, 1974) and expressed as pmoles of resorufin min

${ }^{1} \mathrm{mg}^{-1}$ of microsomal and homogenate protein respectively.

Concentrations of cytochrome $\mathrm{P} 450$ in microsomes were determined spectrophotometrically by a modification of the methods of Omura and Sato (1964). Cytochrome P450 was oxidized with carbon monoxide and reduced with sodium dithionite. The concentration of cytochrome P450 is expressed as nanomoles of cytochrome P450 per $\mathrm{mg}$ of microsomal protein.

(2) Phase II Activity (Glutathine-S-Transferase, GST)

GST activity was determined on cytosol fractions according to the methods of Habig, et al., 1974. GST activity was estimated with glutathione reduced form (GSH, $1 \mathrm{mM}$ ) and 1-chloro-2,4-dinitrobenzene (CDNB) as the substrate in a spectrophotometer at $340 \mathrm{~nm}$. The results were expressed in units of enzyme activity per $\mathrm{mg}$ of protein.

Microsomal and liver homogenate proteins were deturmined using a centrifugal fast analyzer (Cobas Fara) with the Bio Rad protein assay reagent. Bovine serum albumin was used as standard. The protein concentration was expressed as $\mathrm{mg} / \mathrm{ml}$.

Enzyme assays: The activity of 7ethoxyresorufin O-deethylase (EROD) from he xatic microsomes and liver homogenates was measured fluorometrically at $30^{\circ} \mathrm{C}$ (Burke and 
Mayer, 1974) and expressed as pmoles of resonufin min-1 mg-1 of microsomal and homogenate protein respectively.

Concentrations of cytochrome P-450 and cytochrome b-5 in microsomes were determined spectrophotometrically by a modification of the methods of Omura and Sato, (1964). Cytochrome P-450 was oxidized with carbon monoxide and reduced with sodium dithionite. The concentration of cytochrome P-450 is expressed as nanomoles of cytochrome P-450 per mg of microsomal protein. Cytochrome bj was quantified obtaining a NADH difference spectrum (424-413nm) and assuming an extinction coefficient of $185 / \mathrm{cm} / \mathrm{mM}$ and the concentration expressed as nanomoles of cytochrome b-5 per $\mathrm{mg}$ of microsomal protein. The cytochrome b5 assays were performed prior to cytochrome P-450.

Glutathione S-transferase (GST) activity was determined on cytosol fractions according to the methods of Habig et al., 1974). GST activity was estimated with glutathione reduced form ( $\mathrm{CSH}, 1 \mathrm{mM}$ ) and 1 chloro-2,4-dinitrobenzene (CDNB) as the substrate in a spectrophotometer at $340 \mathrm{~nm}$. The results were expressed in units of enzyme activity per $\mathrm{mg}$ of protein.

Microsomal and liver homogenate proteins were determined using a centrifugal fast analyzer (Cobas Fara) with the Bio Rad protein assay reagent. Bovine serum albumin was used as standard. The protein concentration was expressed as $\mathrm{mg} / \mathrm{ml}$.

\section{e. Histology}

Four control and eight DEN-exposed fish were anaesthetized, sacrificed, fixed in Bouin's solution and hematoxylin and eosin slides were prepared for histopathological analysis. Fish were sectioned such that longitudinal sections were made of the entire body minus the caudai fin. Step sections were cut to obtain two paramedian sections each from the right and left sides of the fish and one mid-sagittal section. Two adjacent sections from each of these five planes were mounted for a total of ten sections per fish. This method of sectioning ensures that all major organs of the fish are represented on the slides. 


\section{Results- DEN Exposure 1}

\section{a. DNA Alterations}

\section{(1)DNA Strand Breaks}

Because of the limited amount of liver tissue, an attempt was made to isolate DNA from the low speed pellet in the same samples being used to measure EROD and GST activity. Unfortunately, the conditions of the homogenization were sufficiently severe to shear the DNA polymer and make it impossible to quantify the number of strand breaks caused by the exposure to DEN.

Strand breaks were evaluated in DNA isolated from whole Medaka carcass', and are reported as the F-value in Table II.1. There is a slight, but statistically significant decrease in the duplex:total DNA ratio of the DEN-exposed group, indicating an increased number of strand breaks. Based on these $F$-values, the relative number of strand breaks $(N)$ in the DEN-exposed fish is 0.7 , that is, the DNA of the DEN-exposed animals has $70 \%$ more strand breaks than the DNA from the control animals. This is a relatively small difference in DNA integrity, compared to fish collected from contaminated streams or exposed to low (1) ug/L) concentrations of benzo[a]pyrene (Shugart, 1990c), in which $N$ values can reach levels of 6-10 (6 to 10-fold increases in numbers of strand breaks).

\section{(2) Minor Nucleoside Content}

The only methylated deoxynucleoside in eukaryotic DNA is 5m-dCyd. It has been demonstrated in cell culture that chemical carcinogens and mutagens alter the normal patterns of DNA methylation by interfering with the fidelity of the normal post-replicative modification of the DNA. The hypomethylation of the DNA has been shown to lead to inheritable abnormalities in gene expression. The effect of carcinogens on DNA methylation patterns has been demonstrated in vivo in fish. Bluegill sunfish exposed to BaP $(1 \mathrm{ug} / \mathrm{L})$ for $40 \mathrm{~d}$ experienced a 50\% decline in 5m-dCyd content in their DNA (Shugart, 1990a).

A preliminary analyses of $5 \mathrm{~m}-\mathrm{dCyd}$ content of DNA from Medaka carcasses was done. The results of only a single pair of samples that had been analyzed did not scem to indicate any substantial difference in exposed versus control fish (Table II.1.). Additional analysis and statistical comparisons will be performed. 


\section{TABLE II.1}

Response of Molecular Marker in the Japanese Medaka (Oryzias latipes) From Diethylnitrosoamine Exposure I

\begin{tabular}{|c|c|c|}
\hline Molecular Marker & Control & DEN-Exposed $200 \mathrm{mg} /$ Liter \\
\hline \multicolumn{3}{|l|}{ DNA Alteration } \\
\hline $\begin{array}{l}\text { Strand Breaks" } \\
\text { (liver) }\end{array}$ & $\begin{array}{c}0.4 \pm 0.04^{b} \\
n=10\end{array}$ & $\begin{array}{c}0.20 \pm 0.10 \\
n=30\end{array}$ \\
\hline $\begin{array}{l}{ }^{5} \mathrm{~m}-\mathrm{dC} \mathrm{yd}^{\mathrm{c}} \\
\text { (carcass) }\end{array}$ & 4.8 & 5.5 \\
\hline $\begin{array}{l}\text { DNA Distribution } \\
\text { (hepatocytes) }\end{array}$ & Normal & Aneuploidy \\
\hline \multicolumn{3}{|l|}{ Detoxication } \\
\hline $\begin{array}{c}\text { Phase I-EROD' } \\
\text { (liver) }\end{array}$ & $\begin{array}{c}8.20 \pm 3.76 \\
n=5\end{array}$ & $\begin{array}{c}2.7 \pm 1.2 \\
n=5\end{array}$ \\
\hline $\begin{array}{l}\text { Phase II-GST' } \\
\text { (liver) }\end{array}$ & $\begin{array}{c}534 \pm 88 \\
n=5\end{array}$ & $\begin{aligned} 724 & \pm 213 \\
n & =5\end{aligned}$ \\
\hline
\end{tabular}

- Data reported as $F$ values (percent double stranded DNA after alkaline unwinding); Students " $t$ " Test- control vs DEN exposed- $\alpha>0.001$.

- Mean \pm SD.

c Percent of total deoxycytidine content.

- Represents qualitative interpretation; quantitative and statistical flow cytometric analysis performed for DEN exposure II.

- Picomoles of resorufin produced per minute; Student's " $t$ " Test- control vs DEN exposed$\alpha>0.05<0.001$.

( Enzyme units per mg of protein; Student's " $\mathrm{t}$ " Test- control vs DEN exposed- $\alpha>0.01$ $<0.05$. 


\section{(3) DEN-DNA Add'cess}

DNA adducts refers to a chemical or its metabolite that is covalently bound to DNA. Modification of the DNA by adducts is understood to be a critical event in carcinogenesis and mutagenesis. A wide range of specific ethylated adducts form on DNA following exposure to DEN, and protocols for isolating and quantifying these adducts using HPLC have been well rescribed. Because these procedures are time-consuming and labor-intensive, we have explonod an altemate method for detection of DEN adducts of DNA, the use of monoclonal antibodies to the idducts. The advantages of the antibody approach include (1) adequate sensitivity (adduct levels of 1 adduct per $10^{6}$ to $10^{5}$ can be readily detected), (2) cost-effectiveriess since large numbers of samples can be analyzed simultaneously, and (3) selectivity (levels of a specific adduct can be quantified in the presence of other adducts). Potential problems include concerns that antibody specificity may be compromised because the DNA structure may sometimes be recognized by the antibody, but this can be addressed by enzymatic degradation of the DNA prior to introduction of the antibody.

Samples of DNA purified from medaka carcass' were sent from ORNL to Dr. J. M. Parry, University College of Swansea, Wales, UK, for analysis of $O^{6}$-ethyl guanine adducts, using the monxclonal antibodies he has developed. Of the array of ethylated DNA adducts forned by exposure to DEN, the O'-ethyl guanine adduct was selected because its concentration and persistence has been correlated with tumor formation in several species. Three replicate samples of DNA from the DEN-exposed animals, and four samples from the control animals were assayed, and no $O^{\circ}$-ethyl guanine adducts were detected in any of the samples (detection limits are estimated to be approximately 1 adduct per $10^{6}$ to $10^{7}$ nucleotides).

Given these results, it is perhaps significant to note that this adduct can be enzymatically cleaved by the activity of the enzyme, $O^{6}$-methylguanine-DNA methyltransferase, and that malignarii transformation may be associated with activation of this enzyme. For many, if not most, adducts, including well-characterized carcinogens such as BaP, adducts are removed by excision repair; a long segment of DNA is removed along with tile chemically modified nucleotide and the excised region is then repaired by the activity of DNA polymerase and ligase. In this excision repair process, then, removal of adducts generates strand breaks in 
the DNA which will be detected by the alkaline unwinding procedure. In the case of the $0^{\circ}$ ethyl guanine adducts, however, adducts can be dealkylated enzymatically without causing strand breaks. Hypothetically, it is possible that exposure of the Medaka to DEN activated an alkyltransferase; a DNA repair enzyme ubiquitous to prokaryotes and eukaryotes but not yet characterized in fish (Yarosi, 1985) which removed the adducts but did not result in increased levels of L.VA strand breaks (Table II.1).

\section{(4) Abnormal DNA Distribution in Hepatocytes}

The distribution of DNA content in hepatocytes of exposed and control Medaka were analyzed using a flow cytometer. The DNA content of cells is known to be altered by mutagens, carcinogens and ionizing radiation. The use of a flow cytometer to measure the DNA distribution of cells is recommended by the rapid sampling and low cost of the analyses, and by the large number of cells that can be analyzed. A typical result of an analysis of normal hepatocytes is illustrated in Fig. II.12. The majority of the cells are in the G1, or "resting" stage of the cell cycle. The DNA content of the cells represents the normal diploid compliment of DNA in each cell. Cells in G2, the stage of cell cycle in which the DNA has replicated, but before the cell divides, are tetraploid and have twice the DNA content per cell as a $\mathbf{G l}$ cell.

On a quantitative basis the average number (percentage) of cells with DNA content beyond diploid $\mathrm{GO} / \mathrm{Gl}$ was higher in the exposed medaka livers $(18.9 \%)$ than was found in the medaka livers (12.8\%).

There were qualitative differences in the histograms in the two groups of medaka (Fig. II.1b). The descending side of the diploid GO/GI population in the exposed fish was more diffuse, did not descend to baseline as clearly as in the control samples. This pattern change could be attributable to more cells moving into early $S$ phase of the cell cycle, or mure likely represents the presence of reactive or inflammatory cells in the samples.

Because the stain utilized in the analyses is an intercalating dye, it lias been proposed that as cells become more metabolically active, their DNA unwinds exposing more sites for dye to bind. This gives the appearance of increased DNA within the nucleus. For this reason, we believa the most significant difference, based on very few numbers, is the apparent increase in inflammatory cells in the exposid fish specimens. 


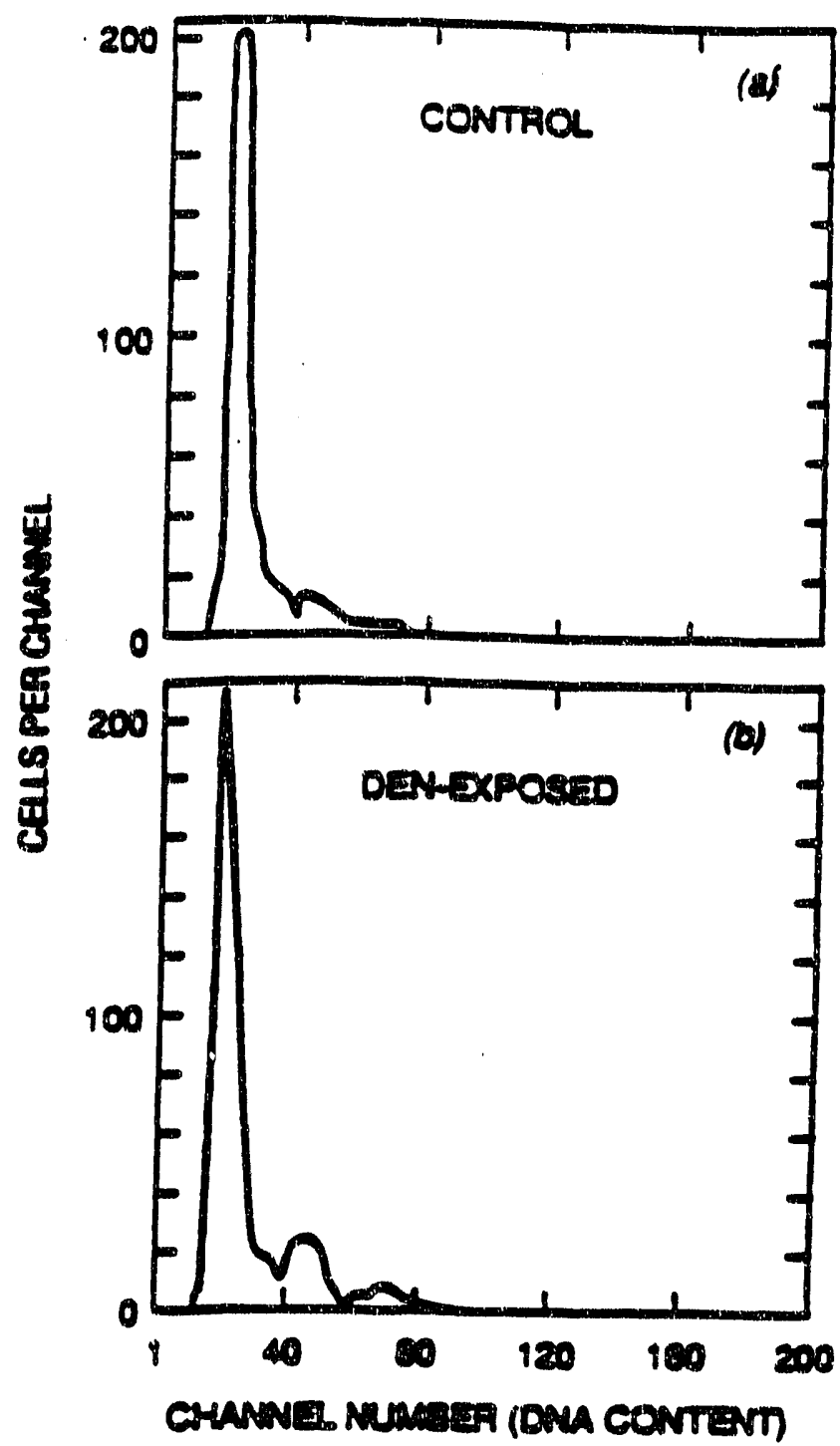

Figure II.1 Frequency histograms of DNA content in heppatocytes. The results of analyses of Japanese medala (Oryzios latipes) hepatocytes from (a) control fish and (b) DEN- exposed fish are shown. The major peak represents cells in the G1 (resting) stage of the cell cycle. 
The numbers of cells in the diploid G2 region also appear to be increased. This difference, however, will require additional studies for confirmation. Some species normally accumulate cells in G2, and the loss of cells in that region represents abnormalcy. More studies would be necessary to evaluate this observation in fish.

\section{b. Histopathology of DEN-Exposed Medaka}

The exposed and control Medaka preserved for histopathological evaluation have not been analyzed at this time. These data will be useful in interpreting the possible causes of the abnormal DNA distribution and other data. It is unclear, for example, if the effects we have described are related to a carcinogenic effects, as evidenced by formation of preneoplastic foci or lesions, or whether the effects reflect a non-cancerous cellular toxicity resulting from exposure to the very high levels of DEN.

\section{c. Enzyme activity studies \\ 1) Development of assay protocols}

EROD activity for fish liver Homogenates: The assay was optimized with respect to $\mathrm{pH}$, temperature, substrate concentration and cofactor using liver homogenates. Two different types of buffers: 1) sucrose $0.25 \mathrm{M}$, Tris $0.1 \mathrm{M}$ (This is the same buffer system in which the livers are homogenized) and 2) Tris $0.1 \mathrm{M}$. The optimum conditions for these two buffer systems are summarized below:

$\begin{array}{lllll}\text { Buffer } & \mathrm{pH} & \text { [EROD] } & \text { Assay Temp. } & \text { [NADPH] } \\ \text { 0.25M Sucrose, Tris } & 7.6 & 1.5 \mathrm{MM} & 30^{\circ} \mathrm{C} & 0.3 \mathrm{mM} \\ \text { Tris 0.1M } & 8.0 & 1.5 \mathrm{uM} & 30^{\circ} \mathrm{C} & 0.3 \mathrm{mM}\end{array}$

Of the two buffers tested, the best results were obtained using $0.1 \mathrm{M}$ Tris buffer. Different volumes of homogenate sample were tested and enzyme rate linearity was obtained under these conditions indicating a proper homogenate protein range for the assay. The amount of homogenate protein used in this assay ranges from 200 to $400 \mu \mathrm{g}$. "The advantage of using liver homogenate in this assay is that of generating more replicates from fewer fish EROD activities for fish microsomes: Hepatic microsomal EROD activity in medaka fish 
were first optimized for $\mathrm{pH}$, then for [NADPH] and finally for substrate concentration. Female and male microsomes were used for the assay optimization. Results are summarized below:

$$
\begin{array}{lllll}
\text { Buffer } & \mathrm{pH} & \text { [NADPH] } & \text { [ethoxyresorufin] } & \text { Assay Temp. } \\
\text { Tris 0.1M } & 8.0 & 0.3 \mathrm{mM} & 1.5 \mathrm{MM} & 30^{\circ} \mathrm{C}
\end{array}
$$

Different volumes of microsomal sample were tested and enzyme rate linearity was obtained under these conditions indicating a proper microsomal protein for the assay. The amount of protein used in this assay varies with the microsomal protein concentration of the sample and ranged from 200 to $375 \mu \mathrm{g}$. A total of twelve livers are needed for four enzyme assays.

GST for cytosolic fraction: This assay is an unusual assay because it requires two different substrate Glutathione (GSH) and CDNB and it therefore very difficult to optimize for both substrate. We decided to keep the GSH concentration at $1 \mathrm{mM}$ because higher concentrations would increase the turbidity of the sample. The optimum conditions are summarized on the following table.

$\begin{array}{lllll}\text { Buffer } & \mathrm{pH} & {[\mathrm{GSH}]} & {[\mathrm{CDNB}]} & \text { Assay Temp. } \\ \text { Phosphate } & 7.4 & 1 \mathrm{mM} & 1.5 \mathrm{uM} & 30^{\circ} \mathrm{C}\end{array}$

Linearity of the reaction was confirmed for different volumes of cytosolic sample. Cytochromes P.450 and b5: Hepatic microsomes were isolated from unexposed medaka fish and their cytochrome P-450 and cytochrome b5 concentration determined. The cytochrome P-450 content in these fish ranged from 0.3 to 0.4 nmoles $/ \mathrm{mg}$ microsomal protein and $0.15 \mathrm{nmoles} / \mathrm{mg}$ for cytochrome b5.

\section{2) Evaluation of Detoxication Enzymes}

Assay conditions for the enzyme assays were optimized with respect to substrate concentration, $\mathrm{pH}$ and temperature using adult fish that had not been exposed to any chemicals. Optimal conditions are listed in Table II.2. The Michaelis Constant (Km) for the EROD activity was determined, and was in the same range as has been reported for the rat 
and for a number of other fish species (McCarthy and Shugart, 1990; Olmeda-Mira, N. personal communication) (Table II.3).

TABLE II.2

Optimum Conditions For Various Enzyme Activities

\begin{tabular}{lll}
\hline & & \\
Buffer & EROD FOR LIVER HOMOGENATES & \\
pH & & Tris-0.1M \\
[7-ethoxyresorufin] & 8.0 \\
Assay Temp. & $1.5 \mu \mathrm{M}$ \\
[NADPH] & EROD FOR LIVER MICROSOMES & $30^{\circ} \mathrm{C}$ \\
& & $0.3 \mathrm{mM}$ \\
Buffer & & Tris-0.1M \\
pH & 8.0 \\
[7-ethoxyresorufin] & & $1.5 \mu \mathrm{M}$ \\
Assay Temp. & $30^{\circ} \mathrm{C}$ \\
[NADPH] & $0.3 \mathrm{mM}$ \\
& & \\
Buffer & GSH-T FOR CYTOSOLIC FRACTIONS & Tris-0.1M \\
pH & & 7.4 \\
[GSH] & $1 \mathrm{mM}$ \\
[CDNB] & $1.5 \mathrm{nM}$ \\
Assay Temp. & $30^{\circ} \mathrm{C}$ \\
\hline
\end{tabular}


Michaelis Constant for EROD activities in various species

SPECIES

Medaka

Croaker

Hogchoker

Toadfish

Scup

Rainbow Trout

Rat
$\mathrm{Km}(\mu \mathrm{M})$

0.11

0.36

0.19

0.16

0.24

0.14

$0.13-0.16$

- EROD - 7-ethoxyresorufin O-deethylase was determined from liver tissue (McCarthy and Shugart, 1990; Olmeda-Mira, personal communication).

EROD purification and recovery were evaluated by comparing activity assayed in the low speed supernatant (referred to as the "homogenate" fraction) and the activity recovered in the purified high speed supernatant (the microsome fraction). As indicated in Table II.4, although the differential centrifugation purified the protein 3-fold, EROD activity in the microsomes was only sightly greater than that observed in the low speed supernatant. The budget of activity and amount of protein showed that over half of the total EROD activity was lost during the purification. This could be due to several reasons, including enhanced denaturation of the protein because of the small volumes and dilute protein concentrations dictated by the size of Medaka livers. Cytochrome P450 spectra indicated a large peak at $420 \mathrm{~nm}$, relative to the peak at $450 \mathrm{~nm}$, suggesting degradation of the cytochrome P450 during purification. The possibility that the cytosol contains an endogenous inhibitor of EROD activity was also tested. Microsomes were isolated and diluted with an equal volume of either the high speed supernatant (the cytosol) or with an equal volume of assay buffer. Results of three EROD assays are shown in Table II.4. EROD activity was 18-38\% lower in the presence of the cytosol, suggesting the possibility of a cytosolic inhibitor. These results 
suggest that for this study, measurements of EROD activity be measured in the low speed supernatant until problems of microsomal purification can be resolved.

TABLE II.4

EROD Purification and Recovery

STEP

EROD

PROTEIN

(Activity) (Unitsb) (Recovery) (Recovery)

Low Speed

8.65

$32.48100 \%$

$100 \%$

Microsomes

11.47

$13.73 \quad 42 \%$

$33 \%$

TEST FOR EROD INHIBITOR IN CYTOSOL OF LIVER

SAMPLE

A

B

C
EROD

(Microso

mes)

12.67

34.52

19.91 $\left(+\right.$ cytosol $\left.^{\circ}\right)$

10.41

23.33

12.34
INHIBITION

17.8

32.4

38.0

- EROD activity is calculated as nanomoles $/ \mathrm{mg} / \mathrm{minute}$.

b Units of EROD activity calculated from (activity X mg-protein).

c Microsomes were isolated and diluted with an equal volume of either high speed supernatant (cytosol) or with an equal amount of assay buffer. Total protein in liver homogenate/assay (low speed and microsomal fraction) ranged from $200-400 \mu \mathrm{g}$.

EROD and GST activity were measured in livers of the Medaka exposed to the DEN and in the control group. EROD activity decreased significantly in the DEN-exposed group (Table II.1); the magnitude and direction of the decrease was similar regardless of whether the enzyme activity was measured in the low speed supernatant or in the purified microsomes. In contrast, GST activity increased over $40 \%$, although the statistical significance of that increase was marginal (Table II.1). The general pattern of depressed 
Phase I activity and enhanced Phase II activity following exposure to genotoxic agents such as DEN has also been observed in rodents (Payne, 1984).

\section{Results- DEN Exposure II}

\section{a. DNA strand breaks in 13 week exposure to DEN}

Alkaline unwinding assays were performed on liver DNA samples of control and DEN exposed medaka. Throughout the thirteen weeks of the experiment the $F$ values of control medaka DNA samples were $F=$ mean $\pm S E M=.47 \pm .045, n=14$. Medaka exposed to 25,50 , and $100 \mathrm{ppm}$ DEN all had an elevated $F$ value relative to controls (ANOVA; $\mathrm{f}=$ 12.2 , alpha $>0.01)(F=.69 \pm 4.9)$ during the first five weeks of the experiment. There was no significant difference (ANOVA; $\mathrm{f}=0.68$, alpha $<0.01$ ) between the $F$ values between the three different DEN exposures $(25 \mathrm{ppm}, F=.73 \pm .050, \mathrm{n}=10 ; 50 \mathrm{ppm}, F$ $=.67 \pm .046, \mathrm{n}=9 ; 100 \mathrm{ppm}, F=.66 \pm .043, \mathrm{n}=9$ ) during the five week exposure. Highest $F$ values were observed during the second and third week of the exposure in all three DEN treated groups and these values declined in the fourth and fifth week. There were no survivors post exposure in the $100 \mathrm{ppm}$ treated group. In the 25 and $50 \mathrm{ppm}$ DEN treated group, $F$ values declined to those of control fish $(F=.45 \pm .089, \mathrm{n}=10)$.

\section{b. DNA distribution in hepatocytes}

Frozen liver tissue samples were sent to Dr. J. Bickham at Texas A\&M University for flow cytometric analysis to determine if DNA content alterations occured in DEN exposed medaka cells. Statistical analysis was performed on pcSAS; Analysis of Variance (ANOVA) was performed to compare treatment groups among one another, invoking Tukey's Studentized Range Test on all the variables (CV, G1, S, G2, PROP1, PROP2, PROP3). Two variables showed a significant difference between pooled controls and experimentals: these were total number of cells in $S$ phase $(P>0.0105)$ and proportion of cells in $S$ phase $(P>0.0024)$. There was no change in the mean channel of the GI peak between the control and the DEN treated fish at any exposure time; therefore, there was no average net loss or gain of DNA content in the diploid cell (G1) population. The only exception was 
observed at week one, where there was a change in DNA content (ANOVA, alpha > 0.05 )(increased and decreased DNA content) of some cell of the G1 population which was seen as an increase in the base with $(\mathrm{CV})$ of the Gl peak (ANOVA, alpha > 0.05). At one week exposure there was a decrease in the number of cells per 10,000 events in the G1 population (ANOVA, alpha > 0.05); this may represent a true decrease in the G0/G1 population, indicating a cytocidal effect of DEN on the resting cell population. The entire cell cycle has been altered in number by the DEN treatment. A possible interpretation may be that dead cells are coming from all parts of the cell cycle in equal proportions decreasing the total number of cells in the cell cycle groups but not changing the percentage of cells in each cell cycle group.

There was no change in the number of cells in the $S$ phase of the cell cycle at week one but there was an increase in the percentage of cells in the $S$ phase of the entire cell cycle. The number and percentage of $S$ phase cells rises through week five; by week seven, the number and percentage of $S$ phase cells is returning to normal. DEN may have killed sensitive dividing cells during the first week of treatment. No cells had moved into this phase of the cell cycle from the $S$ phase compartment yet, By week three, there was a normal number and percentage of cells in the G2/M phase of the cell cycle.

\section{Discussion}

Several molecular and biochemical markers of toxicity have been adapted for measurement in Medaka, and have been applied to describe the effects of treatment of adult Medaka to a high dose of DEN. For the first DEN exposure, DEN treatment inhibited Phase I enzyme activity and increased the activity of a Phase II enzyme; this pattern of response has been described in preneoplastic rodents. No $O^{6}$-ethyl guanine adducts were detected, and only a slight (but statistically significant) increase in DNA strand breaks was observed (control- $F=0.4 \pm 0.01$ SEM, DEN exposed- $F=0.2 \pm 0.1$ SEM: Student's "t" Test- alpha $>0.001)$. Limited numbers of samples have not yet revealed any effects of DEN exposure on $5 \mathrm{~m}-\mathrm{dCyd}$ content of the DNA. These results are consistent with a hypothesis that the prolonged exposure and high levels of DEN induced alkyltransferase 
activity which enzymatically removed any adducts that formed but did not result in strand breaks or hypomethylation of the DNA such as might be expected from excision repair of chemically modified DNA. The results from the second DEN exposure, which was continuous over a five week period, showed a significant increase in $F$ values relative to controls (ANOVA, $\mathrm{f}=12.2$, alpha 0.01). The $F$ values declined to control levels following cessation of DEN exposure This phenomenon was also observed in some of the BaP exposures described in the following section (III), an apparent increase in DNA strand breakage was not observed.

In the first DEN exposure it was observed that the DEN-exposed animals had a significantly greater fraction of hepatocytes in 62 phase of the cell cycle, suggesting increased cellular replication. After a second and continously high DEN exposure which lasied five weeks, the primary effect of DEN exposure was cytocidal across all cell types and stages of the cell cycle in liver tissue which was most pronounced at the end of the first week. After week one, recruitment of new cells was observed via increased cell division (increase in percentage of cells in S phase) Histological evaluation of the DEN-exposed fish should help determine whether these effects can be related to carcinogenic transformations or, alternately, may be attributed to direct cytotoxic effects of the high dose of DEN. Increased cell division and fixation of point mutations (characteristic of alkylating agents) induced by DEN may be an early and important step in hepatic cell carcinogenesis.

\section{References}

Adamkiewics, J.; Eberle, G.; Huh, N.; Nehls, P.; Rajewsky, M. F. (1985). Quantitation and visualization of alkyl deoxynucleosides in the DNA of mammalian cells by monoclonal antibodies. Environ. Health Perspec. 62:49-55.

Burke, M. D.; Mayer, R. T. (1974). Ethoxyresorufin: Direct fluorimetric assay of a microsomal O-dealkylation activity which is preferentially induced by 3methylcholanthrene. Drug Metab__Dispos. 2:583-588.

Daniel, F. B., Haas, D. L. and Pyle, S. M. (1985). Quantitation of chemically induced DNA strand breaks in human cells via an alkaline unwinding assay. Anal. Chem. 144:390-402. 
Fain, H. P. (1986). Interaction of BaP and cadmium on GSH-Transferase and BaP hydroxylase in the black sea bass Centropeisis stiata. Arch. Env. Contam. Texicol. 15:257-263.

George, S. C. and Young, P. (1986). The time course of effects of cadmium and 3-methylcholanthrene on activities of enzymes of xenobiotic metabolism and metallothionein levels in the plaice Pleuronectes platessa. Comp. Biochem. Physiol. $83 \mathrm{C}: 37-44$.

Habig, W. H.; Pabst, M. J.; Jacoby, W. B. (1974). Gluththione-S-transferase: The first step in mercapturic acid formation. L. Biol. Chem. 249:7130-7139.

Jimenez, B. D. and Burtis, L. S. (1989). Influence of environmental variables on the hepatic mixed function oxidase system in the blugill sunfish Lepomis macrochinus. Comp. Biochem. Physiol, 93:11-21.

McBee, K.; Bickham, J. W. (1987). Petrochemical-related DNA damage in wild rodents detected by flow cytometry. Bull Environ. Contam. Toxicol. 40:343-349.

McCarthy, J. F. and Shugart, L. R. (eds.) (1990). Biomarkers of Environmental Contamination. Lewis Publishers-CRC Press, Boca Raton, FL 33431.

McCarthy, J. F., Gardner, H., Wolfe, M. J., and Shugart, L. R. (1991). DNA Alterations and enzyme activites in Japanese Medaka (Oryzial latipes) exposed to diethylnitrosamine Neuroscience Biobehavioral Reviews. 15:92-102.

Omura, T. and Sato, R. (1964). The carton monoxide binding pigment of liver microsomes. L. Biol. Chem. 239:2370-2378.

Payne, J. F. (1988). Mixed function oxygenases in biological monitoring programs: review of potential usage in different phyla of aquatic organisms. In: Persoone, G., Jaspers, E. Claus, C. (eds.) Ecotoxicology Testing for the Marine Environment. vol 1. Bredene, Belgium: State Univewrsity of Ghent and Inst. Mar. Scient. Res., 625-655.

Rydberg, B. (1975). The rate of strand separation in alkali of DNA of irradiated mammalian cells. Bad. Res, 61:274-287.

Shugart, L. R. (1988). Quantitation of chemic ally induced damage to DNA of aquatic organisms by alkaline unwinding assay. Aquat. Toxicol. 13:43-52.

Shugart, L. R. (1990a). 5-methyl deoxycytidine content of DNA from bluegill sunfish exposed to benzo[a]pyrene. Environ. Toxicol. Chem. 9:205-208. 
Shugart, L. R. (1990b). Biological monitoring: testing for genotoxicity. In: McCarthy, J. F.; Shugart, L. R. eds. Biological Markers of Environmental Contaminants.

Chelsea, MI: Lewis Pub. Inc., pp. 205-216.

Shugart, L. R. (1990c). DNA damage as an indicator of pollutant-induced genotoxicity. In: Landis, W. G.; van der Schalie, W. H., eds. 13th Symposium on Aquatic Toxicology and Risk Assessment: Sublethal Indicators of Toxic Stress. Philadelphia, PA: ASTM; 1990c; pp 348-355.

Stegeman, J. J. and Kloepper-Sams, P. J. (1987). Cytochrome P-450 and mixed function oxidase activity in aquatic animals. Env. Health Perspec. 71:87-95.

Wogan, G. N. and Gorelick, N. J. (1985). Chemical and biochemical dosimetry of exposure to genotoxic chemicals. Environ. Health Perspec. 62:5-18.

Yarosh, D.B. (1985). The role of $\mathrm{O}^{6}-$-methylguanine-DNA methyltranferase in cell survival, mutagenesis and carcinogenesis. Mutation Research 145:1-16.

III. MOLECULAR AND CELLULAR MARKERS OF TOXICITY IN THE JAPANESE MEDAKA (Oryzias latipes) EXPOSED TO BENZO[§]PYRENE

1. Summary

Biomarker responses in the Japanese Medaka exposed to benzo[a]pyrene (BaP) dissolved in a Tween 80 vehicle were evaluated over a 16-day exposure period. Data were obtained on BaP uptake, DNA integrity (strand breaks, DNA distribution), detoxication enzymes, and reproductive and developmental parameters. Interpretation of the data obtained to date is not consistent with the occurrence of a physiological response in the medaka to BaP shortly after exposure. Fecundity (daily clutch size) we did not detect (Student' " $t$ " Test) any significant effects on fecundity, number of vitellogenic oocytes, other reproductive parameters, and concomitant genotoxic effects as evidenced by DNA strand breaks in the BaP + Tween 80 exposure.

Additional studies were done to assess DNA damages which included adducts formed by the diol-epoxide metabolite of BaP, and single strand breaks. DNA adducts were detected 
after exposure of 42 hours, but none were detected after 10 day exposure. Strand breaks were detected after 10 days, but not after 42 hours. In conducting strand break studies, it was observed that Medaka DNA resisted unwinding from alkalinity and heat, leading to studies investigating this phenomenon. Exposure to BaP in water was conducted for 51 days, at a concentration of $4 \mu \mathrm{g} / \mathrm{L}$. From blood samples of control and exposed Medaka, along with control bluegill, nuclear chromatin was isolated, and chromosomal/nuclear proteins were studied by SDS polyacrylamide gel electrophoresis. Major differences were observed in the histone fractions between Medaka and bluegill extracted with $\mathrm{NaCl}$, and between exposed and control Medaka, this may account for resistance of medaka DNA to alkaline unwinding. There was a noticeable decrease in non-histone protein in 51 day BaP exposed medaka suggesting that this phenomenon is a consequence of chronic exposure to PAH's and may affect the expression or integrity of the genetic information.

\section{Introduction}

The Japanese Medaka (Oryzias latipes) has been recommended as a model organism to detect carcinogenic, teratogenic, cytotoxic and genotoxic compounds in aquatic systems (Donaldson and Scherer, 1983; Ishikawa et al., 1975). Previous studies with the medaka have focused on carcinogenesis with particular emphasis on the histopathological identification of neoplastic lesions in the tissues of animals exposed to carcinogens. Neoplastic histogenesis in medaka follows a course similar to that observed in rodents: tumor formation is preceded by preneoplastic lesions which appear as both eosinophilic and basophilic foci (Hawkins et al., 1988).

In the medaka, the establishment of experimental protocols for exposure to xenobiotic compounds is particularly important to the development of bioassays for measuring toxicity in this fish. Two cytotoxic and genotoxic compounds were selected for study; diethylnitrosoamine (DEN), and benzo[a]pyrene (BaP) (Taningher et al., 1990). Medaka were exposed to these compounds dissolved in water. This section will focus on recent experiments in which medaka were exposed to BaP dissolved in water. 
One of the primary groups of contaminants of which BaP is included that these studies are concerned with are polycyclic aromatic hydrocarbons (PAH's). It is known that these chemicals are ubiquitous pollutants, and that fish accumulate them through their water and diet. It is also known that some PAH's can be metabolized to more toxic metabolites (Varanasi et al., 1983). A number of metabolites can react covalently with DNA to form adducts (Phillips and Sims, 1979), one of the primary interactions that has been studied. It has also been proposed that the cellular concentration of adducis can be used as an approxi mation of the "biologically effective" dose of the contaminant, and can therefore be used effectively as a measure of exposure (Hoel et al., 1983).

Experiments and bioassays performed to measure exposure of the Japanese Medaka to benzo[a]pyrene ere: 1) determination of the uptake of radiolabeled BaP from water and accumulation of radiolabel in the whole organism; 2) measurement of DNA damage and/or modification by quantitating DNA strand breakage, DNA adducts and nuclear alterations; 3) toxicant-induced changes in reproductive physiology and fecundity; 4) teratogenic studies of the development and hatchability of embryos exposed to xenobiotics; 5) mixed-function oxidases and other detoxication enzyme assays; 6) flow cytometry, and 7) histopathology.

In performing DNA strand break, analysis using the alkaline unwinding method of Shugart (1988) it was observed that while in Bluegill (Lepomis macrochinus), a species of fish used for comparison, a nearly linear relationship exists between temperature of incubation and fractional decrease in fluorescence, this pattern is not observed in medaka (Fig. III.6, see results on page 55). In fact, little if any DNA unwinding is observed at temperatures as high as $50^{\circ} \mathrm{C}$. Further data showed that this effect was even more pronounced in groups exposed to BaP and other xenobiotics (Fig. III.7, see results on page 56). A possible explanation for the observed resistance to unwinding is some natural factor associated with the DNA that is induced in response to xenobiotic exposure. This factor could function to shield the DNA, and/or possibly to aid in DNA repair.

Because it was also observed that proteinase $K$ treatment releases, to a large extent, the effect of the resistance to unwinding, it was concluded that protein is the most likely candidate for the factor(s) causing resistance, although polyamines (Bachrach, 1973), PolyADP-ribose or DNA sequence structures could account for this observation. Research was 
begun to analyze the proteins associated with medaka chromatin to determine the identity of this factor(s), with particular emphasis on the histones as a starting point. Because the histones are intimately involved in determining the structure of chromatin, this group of proteins is believed to be a logical starting point to study the factor(s) responsible for resistance to alkaline unwinding of medaka DNA.

\section{Materials and Methods}

a. Uptake and Accumulation of Radiolabeled Bai

Twenty-five fish (adult Japanese Medaka; 15 female and 10 male; age- 8-10 mo; weight $300-500 \mathrm{mg}$ ) were maintained and exposed at ORNL in one 20-L aquarium. Water in the aquaria was amended with $\left[{ }^{14} \mathrm{C}\right]-\mathrm{BaP}+$ unlabeled $\mathrm{BaP}$ in $1 \%$ Tween 80 (Kennedy et $a l_{.}, 1989$ ) on days $0,2,4$ and 6 of an eight day exposure. The stock solution of $\left[{ }^{14} \mathrm{C}\right]$-BaP was prepared in toluene $\left(1 \mathrm{mCi} / \mathrm{ml} ; 1 \mu \mathrm{J}=1 \mu \mathrm{Ci}=21 \mathrm{ng} \mathrm{BaP}=2.2 \times 10^{\circ}\right.$ $\mathrm{dpm})$. To prepare BaP $+\left[{ }^{14} \mathrm{C}\right]-\mathrm{BaP}$ saturated water, $30 \mu \mathrm{l}$ of $\left[{ }^{14} \mathrm{C}\right]-\mathrm{BaP}$ stock in toluene was dried and dissolved in $100 \%$ methanol, the $\left[{ }^{14} \mathrm{C}\right]-\mathrm{BaP}$ was purified by HPLC on a Varian 5000 Liquid Chromatograph equipped with a $250 \times 4.6 \mathrm{~mm} \mathrm{C18}$ column. Fluorescence was detected with a Schoeffel FS-970 Iluorometer with an excitation monochromter set at $246 \mathrm{~nm}$ and a $370 \mathrm{~nm}$ emission filter. An isocratic flow system using $100 \%$ methanol as solvent was used to elute purified BaP. The $\left[{ }^{14} \mathrm{C}\right]-\mathrm{BaP}$ eluted from the $\mathrm{C} 18$ column was dried and dissolved in $7.5 \mathrm{ml}$ of $1 \%$ Tween 80 containing $40 \mu \mathrm{g} / \mathrm{ml}$ unlabeled BaP; $250 \mu \mathrm{l}$ of this solution was added per liter of aquaria water (per liter: $1 \mu \mathrm{Ci}\left[{ }^{14} \mathrm{C}\right]-\mathrm{BaP} / 21 \mathrm{ng}\left[{ }^{14} \mathrm{C}\right]-\mathrm{BaP} / 10$ $\mu g$ unlabeled BaP).

Medaka were exposed to BaP (21 ng ${ }^{14} \mathrm{C}+10 \mu \mathrm{g}$ unlabeled Bap/L) for 8 days. Each day, $10 \mathrm{ml}$ of water were removed and extracted $2 \mathrm{X}$ with $1 \mathrm{ml}$ of methylene chloride. The extract was centrif zed, the methylene chloride layer separated, dried by evaporation and resuspended in $1 \mathrm{ml}$ of methanol. Replicate samples were analyzed by HPLC as previously described. On sampling days $0,1,2,4$ and 8 five fish ( 3 female and 2 male) were sacrificed by cervical scission. The liver, gonads and carcass of the fish were analyzed separately for ${ }^{14} \mathrm{C}$ content. Frozen tissue was minced and homogenized in 5 volumes of 0.02 
M Tris (pH 7.4) for 1 min using a Virtis Model 45 macro homogenizer. Tissue was treated with pronase (77.5 U/mg in $10 \mathrm{ml}$ buffer; $10 \mathrm{mM}$ Tris-HCl (pH 7.4), $1 \mathrm{mM}$ EDTA, 250 $\mathrm{mM} \mathrm{NaCl}$ ) by adding $1 \mathrm{ml}$ of enzyme $/ 500 \mathrm{mg}$ tissue and incubating for $2 \mathrm{~h}$ at $38^{\circ} \mathrm{C}$. Two $\mathrm{ml}$ of the digest was dispersed in $10 \mathrm{mls}$ scintillation cocktail and analyzed for ${ }^{14} \mathrm{C}$ content by liquid scintillation spectroscopy.

b. BaP Exposure Experiment I- Reproductive and genotoxic Assessment Medaka were maintained at $25-26^{\circ} \mathrm{C}$ in $30 \mathrm{~L}$ glass aquaria with a photoperiod of $16 \mathrm{~h}$ light and $8 \mathrm{~h}$ dark. Three static tanks each contained $70 \mathrm{fish}$; the female to male ratio was 3:2. Fish were fed both flake food (stress Flakes) and freshly hatched brine shrimp daily. One third of the water volume was changed every $48 \mathrm{~h}$ by siphoning; the contaminated water was disposed of through a charcoal filter, and fresh water saturated with BaP was added to replace the water removed.

One aquaria contained $10 \mu \mathrm{g} \mathrm{BaP} / \mathrm{L}$ and $1 \%$ Tween 80 (BaP tank; BaP was added to the water from a concentrated stock solution with $40 \mu \mathrm{g} / \mathrm{ml} \mathrm{BaP}$ in $1 \%$ Tween 80 . The second aquaria was a carrier control, and contained only $1 \%$ Twieen 80 (Tween tank). The third tank was a clean control (control tank). Ten fish ( 6 females ant 4 males) were sampled from each tank on days $1,2,4,8$, and 16. A day 0 sample was also taken from the control tank. Before fish were removed from the tanks, eggs were harvested from females. Water changes on sampling days were made after sample fish were removed.

Fish were sacrificed by cervical scission and the livers, gills, and gonads were removed for analysis. The livers were weighed and placed into small Eppendorf tubes; the tubes were immediately dropped into liquid nitrogen for subsequent DNA alkaline unwinding analysis using a miniprep procedure adopted from Shugart (1988). A pooled sample of twenty $\mathrm{mg}$ of tissue was homogenized in a $1.5 \mathrm{~m}$ Eppendorf microfuge tube in $100 \mu \mathrm{l}$ of 1 $\mathrm{N} \mathrm{NH}_{4} \mathrm{OH} / 0.2 \%$ Triton X-100 followed by addition of $500 \mu \mathrm{l}$ of G-50 buffer (150 mM $\mathrm{NaCl}, 10 \mathrm{mM}$ Tris- $\mathrm{HCl}, 25 \mathrm{mM}$ EDTA, $1 \mathrm{mM} \mathrm{MgCl}_{2}$ ), $\mathrm{pH}$ 7.4. Proteins were removed by extracting the sample with $700 \mu l$ phenol/chloroform/isoamyl alcohol (CIP) followed by extraction with $700 \mu l$ of chloroform. The aqueous layer was removed after centrifugation 
and G-50 buffer in $1 \mathrm{M} \mathrm{NaCl}$ was added to a final volume of $2 \mathrm{ml}$. The samples were then analyzed for DNA alkaline unwinding.

The ovaries were weighed and placed in L-15 culture medium. The carcass was placed in $1.5 \mathrm{ml}$ Eppendorf tubes and stored in liquid nitrogen. Ovarian tissue was examined for oocyte size, fecundity (daily clutch size), numbers of vitellogenic oocytes, and oocyte atresia (Greeley, et al., 1987; Lin, et al., 1989).

Fertilized eggs were placed into hatching solution immediately after being removed from the females (medaka hatching solution: $0.017 \mathrm{M} \mathrm{NaCl}, 0.40 \mathrm{mM} \mathrm{KCl}, 0.27 \mathrm{mM} \mathrm{CaCl}{ }_{2}$ $2 \mathrm{H}_{2} \mathrm{O}, 0.66 \mathrm{M} \mathrm{MgSO}, 7 \mathrm{H}_{2} \mathrm{O}, 1 \mathrm{mg} / \mathrm{L}$ methylene blue). The eggs were separated with fine forceps under a dissection microscope, and each individual clutch was divided into equal numbers and placed into petri dishes $(60 \times 15 \mathrm{~mm})$. Replicate dishes held between 9-25 eggs. The width of the perivitelline space was determined by subtracting the outer sphere diameter from the inner sphere diameter by measurement (in mm) under a dissection microscope for each individual sample. Eggs were then incubated at room temperature and allowed to develop. These were observed daily for embryonic death and developmental staging (Kirchen and West, 1976, Carolina Biological Supply, Inc.). Death of the embryo was determined by uptake of the methylene blue dye. Time to hatch and hatching success were also recorded. Fry which hatched were moved to small culture dishes and fed from cultures of mixed paramecium and mixed nematodes for $8 \mathrm{~d}$. They were then fed a regular diet of brine shrimp and Stress Flakes.

\section{c. BaP 7 Day Exposure Experiment II- DNA Damage assessment}

Adult medaka (male and female; age-8-10 mo.; weight-300-500 mg) were divided into four treatment groups with 5 fish per tank: A) 15 fish, untreated control; B) 15 fish treated with verapamil (1 $\mu \mathrm{g} / \mathrm{L})$; C) 15 fish treated with $\mathrm{BaP}(4 \mu \mathrm{g} / \mathrm{L})$; and D) 15 fish treated with verapamil (Kurelec and Pivcevic, 1989), which inhibits the p-170 glycoprotein pump and subsequent removal of xenobiotic compounds from cells, 1$) \mu g / L)$ and BaP (4 $\mu \mathrm{g} / \mathrm{L}$ ). Medaka from each group were maintained in thre aquaria containing $8 \mathrm{~L}$ of water. BaP saturated water was prepared by passage through a Generator column containing glass beads coated with BaP (Shiu et al., 1988). No additional BaP water was added to the Bap 
and the BaP + verapamil tanks during the experiment. Tanks which contained verapamil were given a daily dose of verapamil dissolved in methanol; the doses were sufficient to deliver a final concentration of $1 \mu \mathrm{g} / \mathrm{L}$ of the drug. After 7 days of exposure, the medaka were sacrificed by spinal scission. The DNA from individual whole fish was extracted and analyzed using the alkaline unwinding assay as described by Shugart, 1988.

\section{d. Bap 10 Day Exposure Experiment III- DNA Damage Studies}

Adult medaka (male and female; age- 8-10 mo.; weight-300-500 mg) were exposed for $10 \mathrm{~d}$ to $\mathrm{BaP}$ and BaP + verapamil in a small scale follow-up mini-exposure experiment. Three treatment groups were A) 12 fish (6 fish/replicate), untreated control; B)

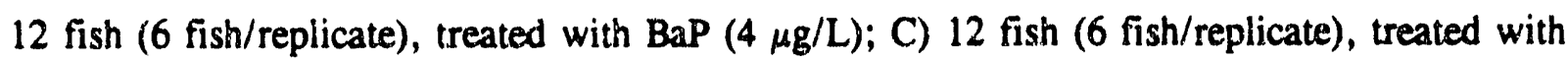
Verapamil $(1 \mu \mathrm{g} / \mathrm{L})$ plus $\mathrm{BaP}(4 \mu \mathrm{g} / \mathrm{L})$. The fish were maintained in small aquaria, each of which contained $5 \mathrm{~L}$ of water. BaP concentrations were maintained at a constant level by continuous saturation with a BaP generator. Verapamil, dissolved in methanol, was added daily to a concentration of $1 \mu \mathrm{g} / \mathrm{L}$.

After $42 \mathrm{~h}$ and $10 \mathrm{~d}$ exposure six fish were removed from each treatment group at both sampings. The fish were sacrificed by spinal scission and DNA was purified from whole individual fish by a modified procedure adopted from Maniatis et al., (1982). Whole fish were homogenized in a $10 \mathrm{ml}$ glass homogenization tube with ten strokes of a teflon pestle in $3 \mathrm{ml}$ of extraction buffer (10 mM Tris-HCl, pH 7.4; $1 \mathrm{mM}$ EDTA and $250 \mathrm{mM}$ $\mathrm{NaCl}$ ). To the homogenate was added $250 \mu \mathrm{l}$ of $10 \%$ Sarkosyl and $50 \mu \mathrm{l}$ of RNAase (2 $\mathrm{mg} / \mathrm{ml}$ stock, DNAase-free RNAase). The mixture was incubated at $50^{\circ} \mathrm{C}$ for $30 \mathrm{~min}$ to digest RNA. Incubation continued for an additional $60 \mathrm{~min}$ after $6 \mu$ lof proteinase $\mathrm{K}$ solution $(10 \mathrm{mg} / \mathrm{ml}$ stock solution) was added. The contents of the tubes were gently shaken during incubation to ensure complete digestion of RNA and protein.

After incubation, the digested samples were transferred $106 \mathrm{ml}$ SST serum separation vacutainer tubes. An equal volume of CIP (phenol-chloroform-isoamyl alcohol; 25:24:1) was added and the tubes mixed by inversion for $5 \mathrm{~min}$. They were then centrifuged at $3000 \times \mathrm{g}$ for $20 \mathrm{~min}$ at room temperature and the aqueous phase re-extracted in chloroform to remove traces of phenol. The aqueous phase was collected, and the DNA in this phase was 
precipitated by adding 2 volumes of cold $100 \%$ ethanol. DNA was pelleted by centrifugation at $3000 \times \mathrm{g}$ for $20 \mathrm{~min}$ before being briefly dried in a vacuum and resuspended in $3.5 \mathrm{ml}$ of alkaline unwinding buffer (10 mM Tris- $\mathrm{HCl}, \mathrm{pH} 7.4 ; 1 \mathrm{mM}$ EDTA and $250 \mathrm{mM} \mathrm{NaCl})$. Alkaline unwinding analysis was performed according to the procedure described by Shugart (1988).

\section{e. $\quad 51$ Day BaP Exposure IV-Chromatin analysis}

Exposure was similar to BaP exposure III, but for 51 days, but minus the BaP + verapamil treatment group. At the end of that time, chromosomal and nuclear protein samples were obtained from isolated blood cell chromatin. Isolation of nuclei was done by a modification of a procedure of Hewish and Burgoyne (1973). Two medaka were placed in a small beaker containing $4 \mathrm{mls}$ of buffer 1 (15 mM Tris, $15 \mathrm{mM} \mathrm{NaCl}, 15 \mathrm{mM} \beta$-mercapto ethanol, $60 \mathrm{mM} \mathrm{KCl}, 0.5 \mathrm{mM}$ spermidine, $0.15 \mathrm{mM}$ spermine, $0.34 \mathrm{M}$ sucrose, $2 \mathrm{mM}$ EDTA, $0.5 \mathrm{mM}$ EGTA, pH 7.4). The fish were decapitated, and blood was collected by filtration through glass wool using a Pasteur pipet. The solution was transferred to a test tube, and centrifuged for 5 minutes at $1000 \mathrm{rpm}$ on a Dynac tabletop centrifuge. The supernatant was drawn off, and the cellular pellet was resuspended in $2 \mathrm{mls}$ of buffer 1 . This washing procedure was repeated a total of 3 times, after which the pellet was resuspended in buffer 2 (identical to buffer 1 but made up to 0.5\% NP-40). Samples were washed twice, using 5 minute, $1500 \mathrm{rpm}$ centrifugation in order to pellet nuclei. Samples were then washed twice in buffer 3 (15 $\mathrm{mM}$ Tris, $15 \mathrm{mM} \mathrm{NaCl}, 15 \mathrm{mM} \beta$-mercapto ethanol, $0.5 \mathrm{mM}$ spermidine, $0.15 \mathrm{mM}$ spermine, $0.34 \mathrm{M}$ sucrose, $1 \mathrm{mM} \mathrm{PMSF}, \mathrm{pH}$ 7.4). After the second wash, the pellet was resuspended in $500 \mu \mathrm{L}$ of distilled water, with $20 \mu \mathrm{L}$ of $2.0 \%$ SDS in buffer 3. Samples were spun on an Eppendorf Microfuge at 13,000 rpm for 2 minutes. The supernatant containing chromatin was collected and frozen for later use. Some samples, instead of freezing immediately, were ethanol precipitated using 2 volumes of icecold $100 \%$ ethanol.

Chromatin proteins were analyzed using SDS polyacrylamide gel electrophoresis (SDS/PAGE) with a 13\% acrylamide concentration by the procedure of Laemmli (1970; Miller, 1988), for chromatin and nuclear protein molecular weight analysis. Precipitated 
samples were redissolved in pure sample solution $(1.52 \mathrm{~g}$ Tris base, $20 \mathrm{ml}$ of glycerol, $2.0 \mathrm{~g}$ of SDS, $2.0 \mathrm{ml}$ of 2-mercaptoethanol, $1 \mathrm{mg}$ of Bromphenol Blue in $100 \mathrm{ml}$ of water, $\mathrm{pH}$ 6.8), while raw chromatin samples were dissociated in 2 volumes of sample solution. A weaker dissociation was performed by making the nuclear lysates up to $2 \mathrm{M} \mathrm{NaCl}$ and dissolving in an equal volume of sample solution. All samples were then boiled for 5 minutes, and centrifuged on an Eppendorf centrifuge for 2 minutes at 13,000 rpm before application to the gel which were electrophoresed at 25-35 ma for 4 hours.

The gels were stained, either by Coomassie blue, as described by Ausubel et al. (1989), or by silver stain, according to the procedure described by Ausubel et al. (1989) modified from a procedure described by Oakley et al. (1980). The gels were scanned on a LKB Ultroscan Laser Densitometer.

4. Results

a. Uptake and Accumulation of Radiolabeled BaP

$\mathrm{BaP}$ in the water during the $8 \mathrm{~d}$ experiment declined following each water renewal event and radiolabeled $\left[{ }^{14} \mathrm{C}\right]-\mathrm{BaP}$ accumulated in the medaka (Fig. III.1 and III.2). The initial rate of $\left[{ }^{16} \mathrm{C}\right]-\mathrm{BaP}$ accumulation into whole body tissues of the fish was high; during the remainder of the exposure time, it was lower (Fig. III.2). BaP appeared to concentrate more in the tissues of female medaka than in the tissues of the males but sample number was too few to statistically verify this observation (Fig. III.3).

\section{b. Bap Exposure Experiment I}

The reproductive parameters (Table III.1; days 1 and 16 of exposure) compares fecundity, number of immature vitellogenic oocytes, female GSI, and Docyte Atresia, of BaP-treated fish during the $16 \mathrm{~d}$ experiment. Comparisons of values (means \pm SEM) among treatment groups showed no difference based on Student's " $t$ " Test $(p>0.05)$. 


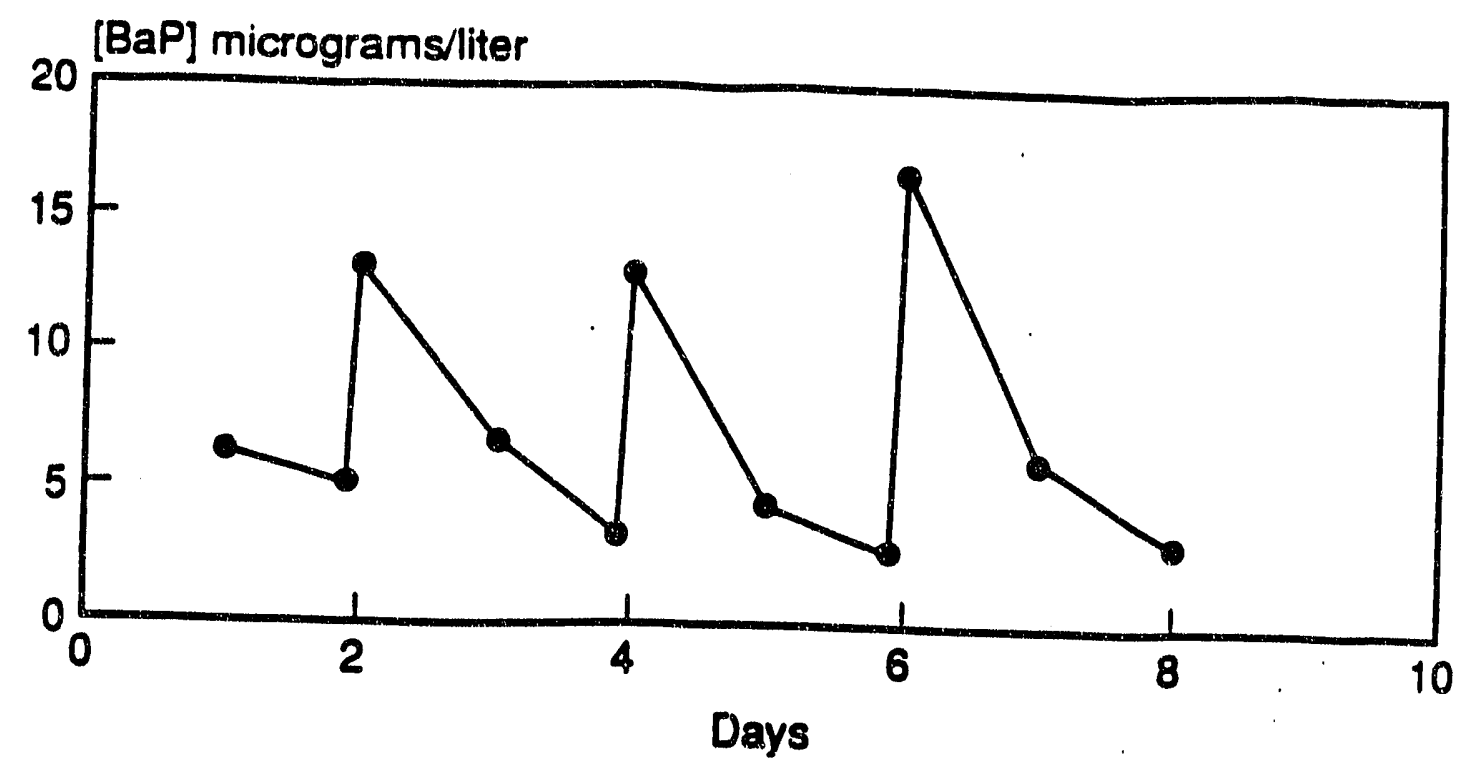

\section{BaP concentration}

Figure III.1 Bap concentration in water during exposure of medala to $\left[{ }^{14} \mathrm{C}\right]-\mathrm{BaP}$ for 8 days. Fish were maintained in $15 \mathrm{~L}$ of water in $20 \mathrm{~L}$ aquaria supplemented with $21 \mathrm{ng}\left[{ }^{14} \mathrm{C}\right]-\mathrm{BaP}+10 \mu \mathrm{g}$ uniabeled BaP added to the water on days 0,2 ,
4 , and 6 .

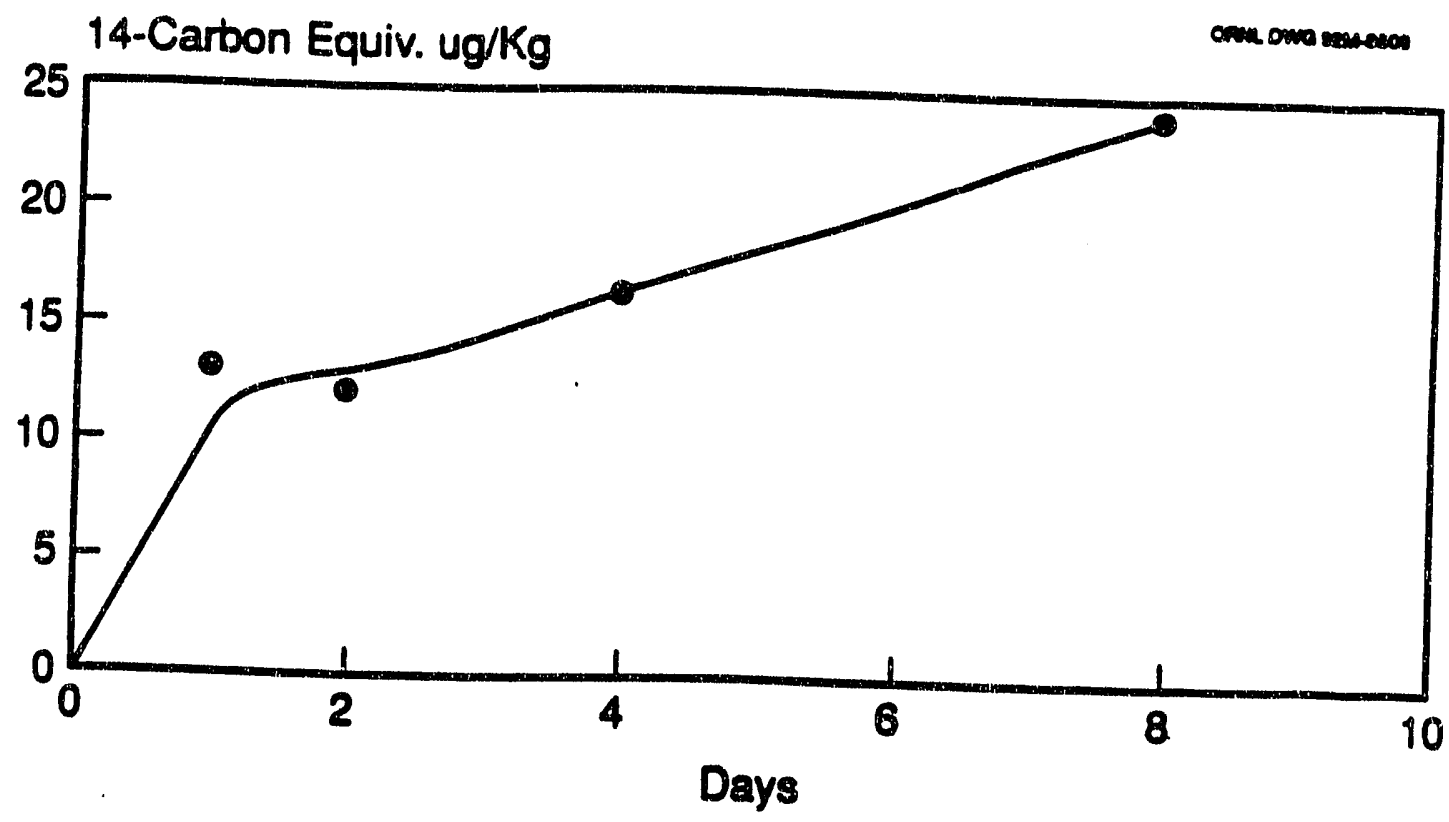

$\rightarrow$ Bap concentration

Figure III.2 BaP accumulation in medaka: Accumulation of BaP in $\left[{ }^{4} \mathrm{C}\right]$ equivalents $\left(\mu \mathrm{g} / \mathrm{K}_{\mathrm{g}}\right)$ in whole body tissues of adult medaka over time. $\mathrm{n}=10$ male and 15 female fish analysed at day $1,2,4$, and 8 exposure. 


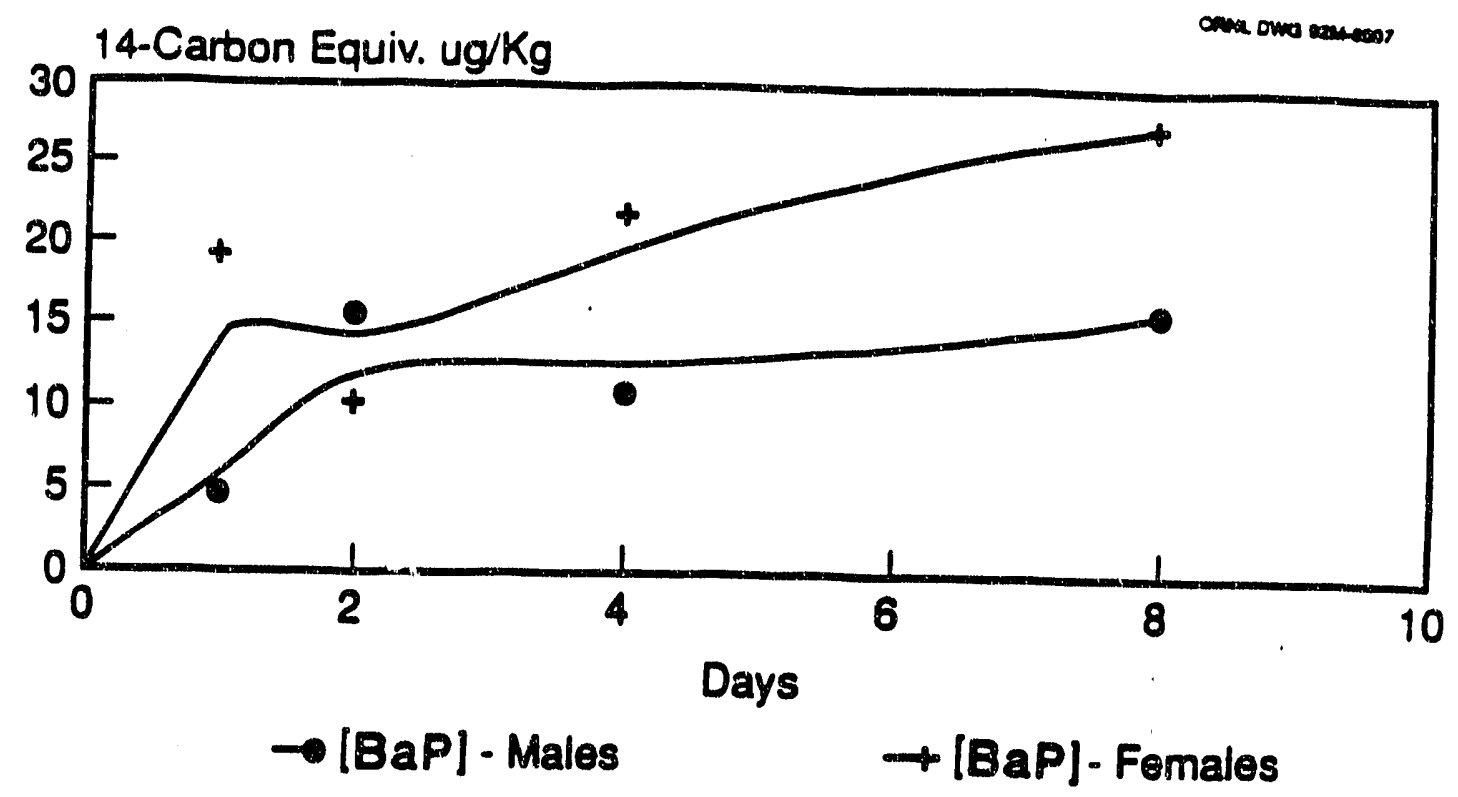

Figure III.3 Accumulation of BaP in maie vs. female medaka. BaP concentration in tissues is represented by $\left[{ }^{14} \mathrm{C}\right]$ equivalents in whole body tissues of male and female fish. $n=10$ and 15 females analysed at days $1,2,4$, and 8 exposure.

TABLE III.1

Medaka Reproduction

\begin{tabular}{llcccc}
\hline Dayy & Treatment & female GSP & Fecundity & Atresia & $\begin{array}{c}\text { Vitellogenic } \\
\text { Oocytes }\end{array}$ \\
\hline \multirow{2}{*}{1} & Control & $5.5 \pm 0.4^{\circ}$ & $6.1 \pm 1.1$ & $0.3 \pm 0.2$ & $68.2 \pm 7.6$ \\
& Tween 80 & $4.5 \pm 0.9$ & $8.5 \pm 2.8$ & $0.7 \pm 0.7$ & $68.8 \pm 18.5$ \\
& BaP & $5.3 \pm 0.3$ & $5.5 \pm 1.7$ & $6.5 \pm 5.5$ & $85.8 \pm 19.4$ \\
$16 \quad$ Control & $5.7 \pm 0.5$ & $11.3 \pm 2.4$ & $1.3 \pm 0.8$ & $94.5 \pm 16.4$ \\
& Tween 80 & $4.4 \pm 0.5$ & $5.8 \pm 1.1$ & $1.5 \pm 0.6$ & $70.2 \pm 6.5$ \\
& BaP & $6.0 \pm 0.3$ & $13.3 \pm 1.4$ & $0.8 \pm 0.5$ & $113.5 \pm 10.8$ \\
\hline
\end{tabular}

- GSI: Gonadal Somatic Index; (ovary weight/body wt) X 100.

- Fecundity: The number of mature eggs released per ovary or daily clutch size.

- Atresia: The number of dead or damaged oocytes per ovary.

- Vitellogenic Oocytes: The number of yolk-containing oocytes per ovary.

- Values represented as means \pm SEM; $n=6$ in each case. 
The results from the developmental studies are summarized in Table III.2. No significant difference ( $t$-Test; alpha $>0.05$ ) was found in the overall size of the eggs, the inner diameters or the difference between the two for all three treatment groups. These measurements were made under a dissection microscope within $6 \mathrm{~h}$ of fertilization and the data from each set of replicate plates were pooled for this analysis. Exposure to BaP and Tween 80 had no obvious effect on the morphology of fertilized eggs. The average number

TABLE III.2

Medaka Development

\begin{tabular}{|c|c|c|c|}
\hline PARAMETER & CONTROL $n=21$ & TWEEN $80 n=15$ & $\mathrm{BaP}^{\prime \prime} \mathrm{n}=36$ \\
\hline $\begin{array}{l}\text { Outer diam. of fertilized } \\
\operatorname{eggs}^{b}(\mathrm{~mm})\end{array}$ & $1.25 \pm 0.06^{c}$ & $1.20 \pm 0.06$ & $1.25 \pm 0.05$ \\
\hline $\begin{array}{l}\text { Inner diam. of fertilized } \\
\text { eggs }^{b}(\mathrm{~mm})\end{array}$ & $1.10 \pm 0.06$ & $1.10 \pm 0.06$ & $1.10 \pm 0.06$ \\
\hline $\begin{array}{l}\text { Size of the perivitelline } \\
\text { space in fertilized eggs }\end{array}$ & $0.15 \pm 0.06$ & $0.15 \pm 0.05$ & $0.15 \pm 0.05$ \\
\hline $\begin{array}{l}\text { Number of days over which } \\
\text { hatching occurred }\end{array}$ & $8.00 \pm 1.41$ & $4.50 \pm 3.53$ & $7.33 \pm 0.58$ \\
\hline $\begin{array}{l}\text { Days from fertilization to } \\
\text { last hatch }\end{array}$ & $12.75 \pm 2.43$ & $12.73 \pm 3.02$ & $15.24 \pm 2.61$ \\
\hline Fry survival & $83.3 \%$ & $90.9 \%$ & $67.3 \%$ \\
\hline
\end{tabular}

- 10 ppb BaP in 1\% Tween 80 .

- Day 16 of exposure; mean \pm SEM.

c $\pm \mathrm{SE}$. 
of days over which hatching occurred was obtained by monitoring replicate plates within each treatment group. For example, on day 0 , there were three replicate plates of embryos which hatched over a four and a half day period. In contrast, controls on day 16 had two replicate plates and the eggs on these pletes required an average of 8 days from the first hatch to the last hatch. No significant difference ( $t$-Test; alpha $>0.05$ ) was found between the groups when analyzed this way. All replicate plates were pooled for determination of the time of fertilization to the last hatch. No significant differences $(t-T e s t ;$ alpha $>0.05)$ were seen between groups. The percent survival of successfully hatched fry in each group was determined over a 30 day period). Since all fry from individual petri dishes were maintained in the same culture it was impossible to separate deaths that occurred as a result of transfer of fry with glass pipettes from any which might have been caused by exposure to BaP or Tween 80.

Alkaline unwinding analysis was performed on liver DNA from the medaka using the mini-prep method. The alkaline unwinding $F$ values (fraction of the DNA in double stranded form) are shown at days $0,1,2,4,8$ and 16 (Fig. III.4). The means of the alkaline unwinding $F$ values within the three treatment groups were quite variable and are not significantly different on day 16 of exposure (ANOVA: $f=0.774 ; f_{0.05}=5.14$, alpha > $0.25)$.

\section{c. BaP Exposure Experiment II}

The alkaline unwinding $F$ values from the second BaP experiment are shown in Fig. III.5. The $F$ values for these four treatment groups were essentially the same except that DNA from fish treated with both verapamil and BaP had higher $F$ values at $38^{\circ} \mathrm{C}$ (ANOVA: $\mathrm{f}=152.3, \mathrm{f}_{0.06}=i .92$, alpha $<0.001$ ). Medaka DNA from all four exposure groups was quite resistant to alkaline unwinding even at a temperature of $50^{\circ} \mathrm{C}$. 


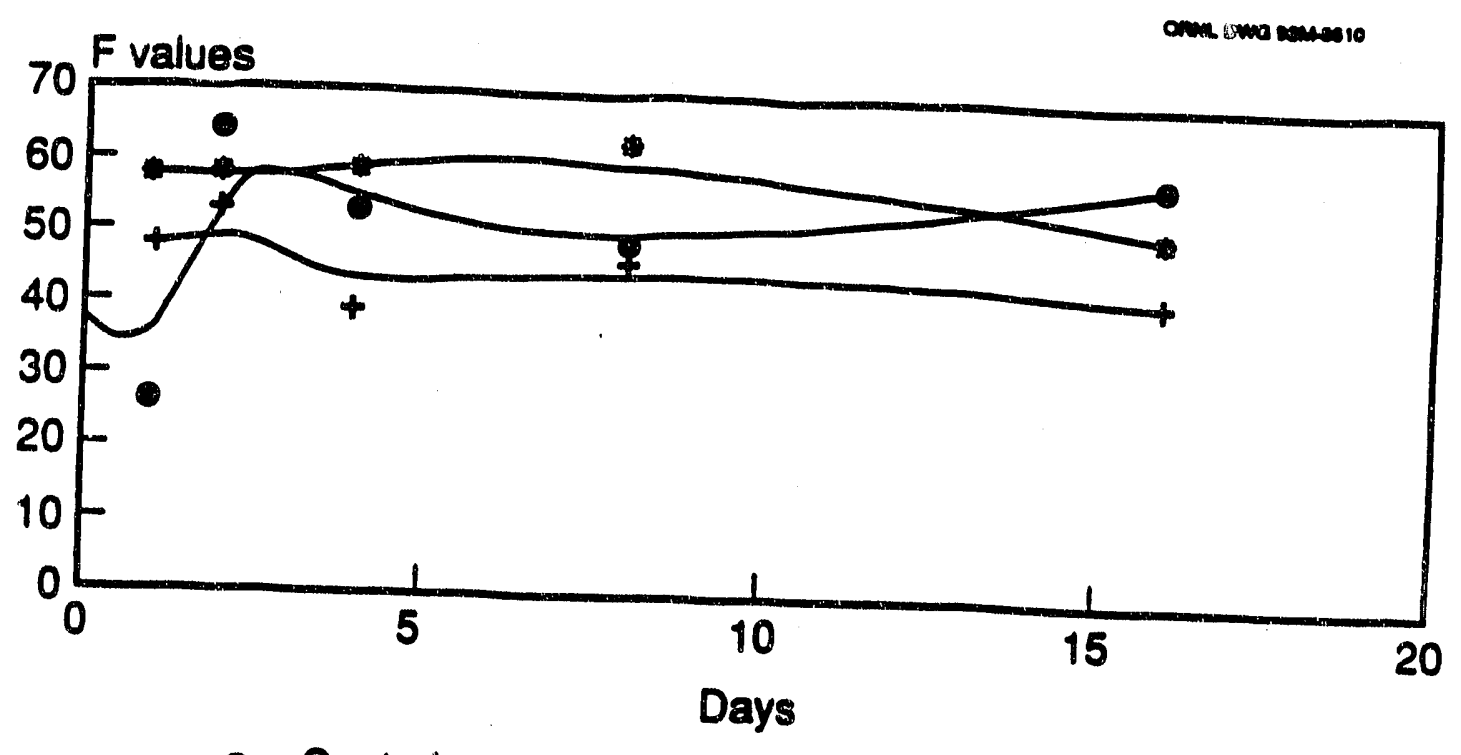

$\rightarrow$ Control $\rightarrow$ Tween $80 \rightarrow$ BaP + Tween 80

Figure III.4 $F$ values for DNA of medake exposed to BaP in "exposure I". Medaka were exposed to $10 \mu \mathrm{g} / \mathrm{L} \mathrm{BaP}+1 \%$ Tween 80 and to $1 \%$ Tween 80 alone for 16 days. One third the water volume was removed and replaced with BaP + Tween 80 (same conc.) every 48 hours.

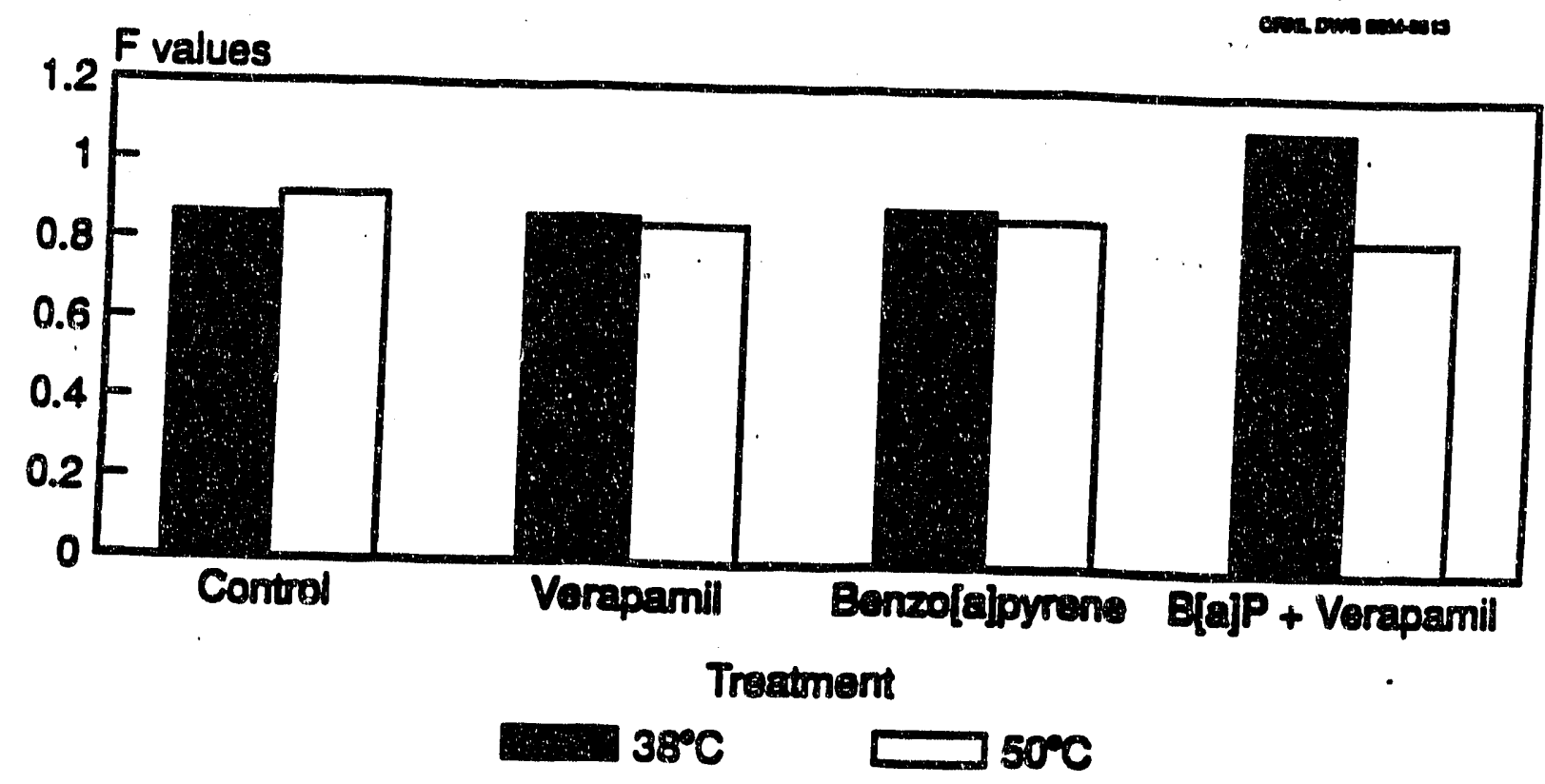

Figure IIT.5 F values for DNA medala exposed to BaP in "exposure II". Medala were exposed for 7 days to an initial concentration of $4 \mu \mathrm{g} / \mathrm{L}$ BaP without water changes and Bap supplementation after day one. 
Fig. III. 6 shows a comparison of the extent of allaline unwinding (measured by the decrease in fluorescence of DNA + Hoechst dye 33258) of BaP exposed medata DNA with increasing temperature. Medaka DNA was resistant to unwinding between $23^{\circ} \mathrm{C}$ and $50^{\circ} \mathrm{C}$, but began to unwind at higher temperatures.

Medaka DNA from the three exposed groups (BaP, verapamil, and BaP + verapamil had an increased resistance to alkaline unwinding ( about a $25 \%$ decrease in fluorescence) in contrast to control and fresh, salt extracted DNA (about a $45 \%$ decrease in fluorescence) after 60 minutes of incubation as shown in Fig. III.7 (ANOVA: $f=39.25, f_{0.08}=2.87, p<$ $0.001)$. A decrease in fluoresence over time reflected the change of double strand DNA to single strand DNA in the presence of Hoescht dye $\$ 33258$.

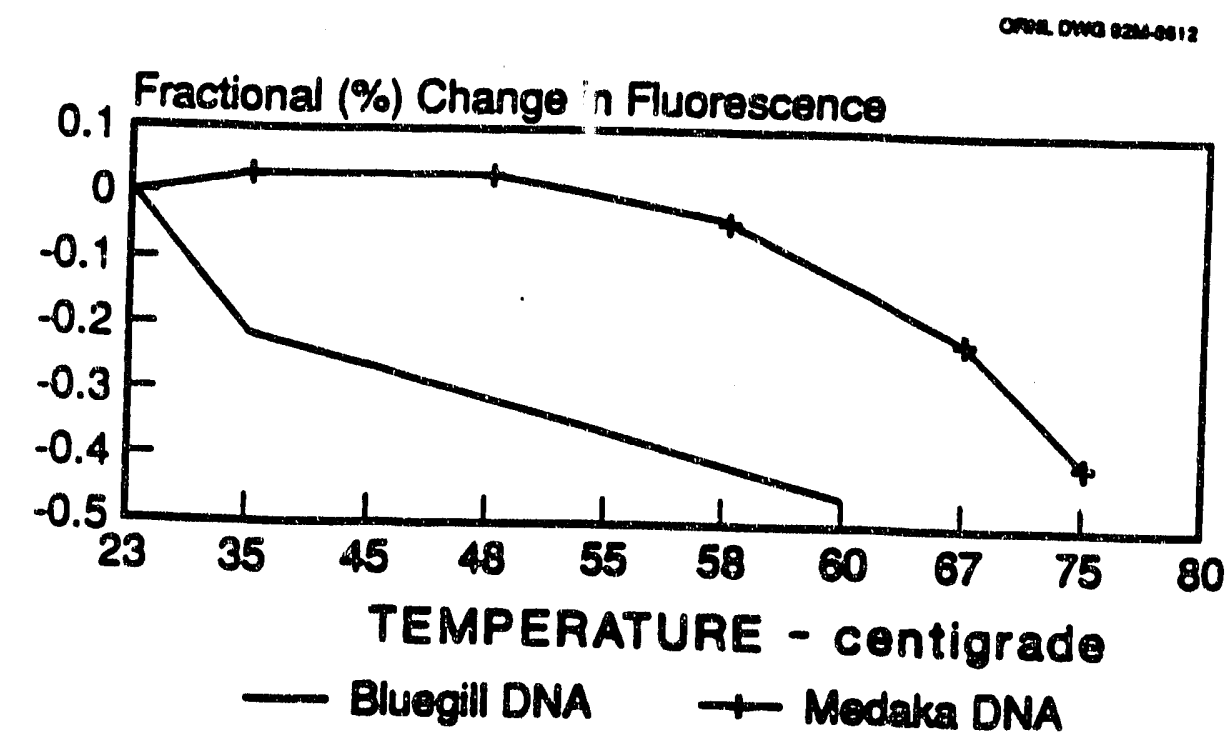

Figure III.6 Thermal denaturation of BaP treated medala DNA under alkaline conditions. Medaka and bluegill were exposed to a constant BaP concentration of $4 \mu \mathrm{g} / \mathrm{L}$ for 7 days. The extent of fluorescence of DNA + Hoechst dye 33258 with increasing temperature. 


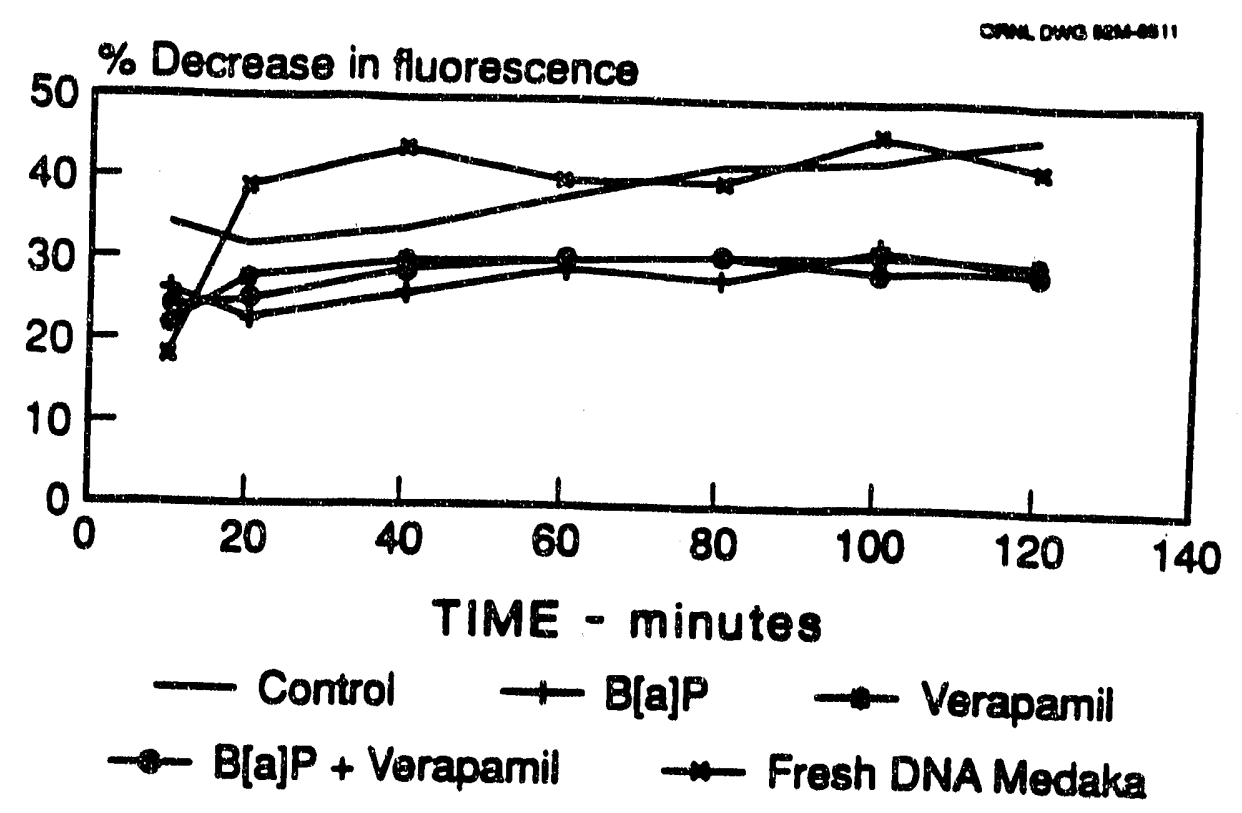

Figure III.7 Comparison of alkaline unwinding of medala DNA from control, BaP. (4 $\mu g / L)$ and verapamil $(1 \mu g)$ exposed fish. Fish were exposed for 7 days. The degree of alkaline unwinding was determined as the percent decrease in fluorescence over time at $60^{\circ} \mathrm{C}$.

\section{d. BaP Exposure Experiment III}

Fig. 10.8 shows the allaline unwinding $F$ values for medala DNA from BaP exposure III. The yield of high molecular weight DNA. was considerably higher than $\mathrm{NH}_{4} \mathrm{OH} / \mathrm{Tr}$ ton X-100 extraction, possibly due to more efficient removal of protein which reduces loss of DNA to the aqueous interface during phenol extraction. The increased yield of DNA should make possible multiple DNA analyses from a single fish. In addition, there was considerable unwinding of the DNA at lower temperatures in contrast to DNA extracted in NH,OH/Triton X-100, which was highly resistant to unwinding.

After a 42h exposure, no DNA strand breaks were observed (Fig. Im.8). Allkaline unwinding analyses were performed at $4^{\circ} \mathrm{C}, 38^{\circ} \mathrm{C}$, and $52^{\circ} \mathrm{C}$, (ANOVA- only on $38^{\circ} \mathrm{C}$ and $52^{\circ} \mathrm{C}: \mathrm{f}=0.0123, f_{0.05}=3.89, \mathrm{p}>0.25$ at $38^{\circ} \mathrm{C} ; \mathrm{f}=1.88, \mathrm{p}>0.10 ; \mathrm{f}_{0.05}=3.89$, at $52^{\circ} \mathrm{C}$ ) none of which showed any difference among the three treatment groups. The BaP metabolite Tetrol I-1, which is the predominate form, was observed at a level of 0.5-1.25 ng/mg of hydrolysed DNA in BaP and (BaP \& verapamil) exposed fish (Fig. III.9). 

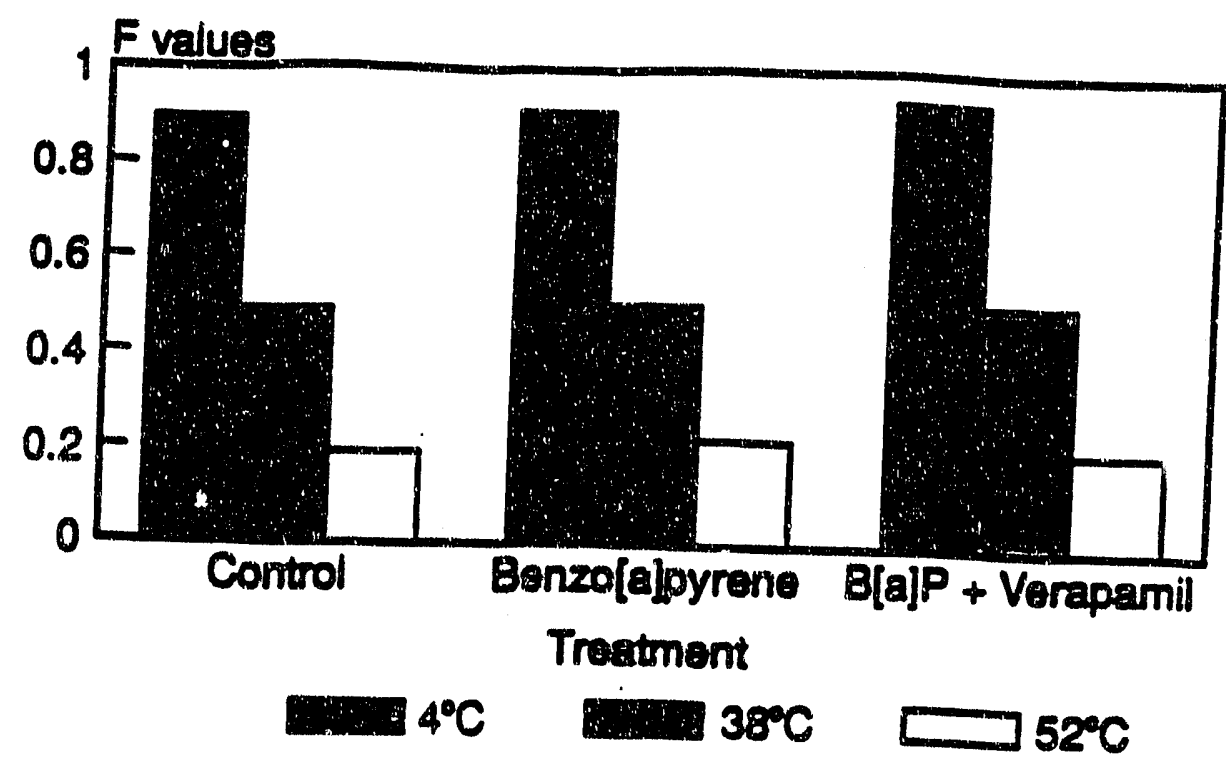

Figure III.8 Comparison of alkaline unwinding $F$ values from modaka exposed to a constant BaP concentration of $4 \mu \mathrm{g} / \mathrm{L}$ for 42 hours BaP exposure. DNA was purified by a modified procedure which extensively deproteinated the DNA during purification.

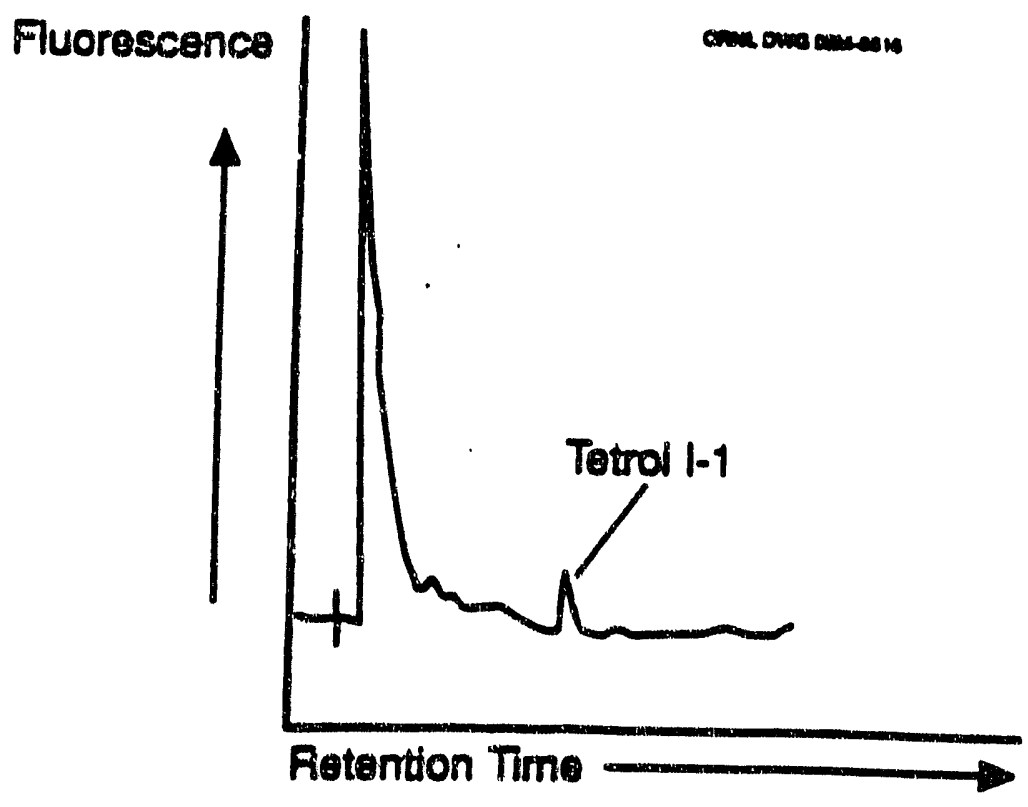

Figure Im.9 BaP-tetrol adducts in medaka DNA exposed to a constant concentration of BaP of $4 \mu \mathrm{g} / \mathrm{L}$ for 42 hours. Adducts were determined by HPLC fluorescence analysis of terols liberated from DNA by acid Hydrolysis. 
After 10 day exposure, a low level of strand breaks, at $25^{\circ} \mathrm{C}$ alkaline unwinding, may have been present (Fig. III. 10), but was not significant by ANOVA ( $f=2.60, f_{0.05}=3.68$, alpha > 0.05). F values were $.225 \pm .020$ (mean \pm SEM) for the control group, .180 \pm . .017 for the BaP exposed group, and $.167 \pm .030$ for the BaP and verapamil exposed group. $F$ values in this experiment were at the lower optimal range for DNA and may have resulted from DNA shearing during purification or is characteristic uf DNA that has been highly purified with Proteinase $K$ and RNAase treatment. No adducts were detected in this exposure (Fig. III.11).

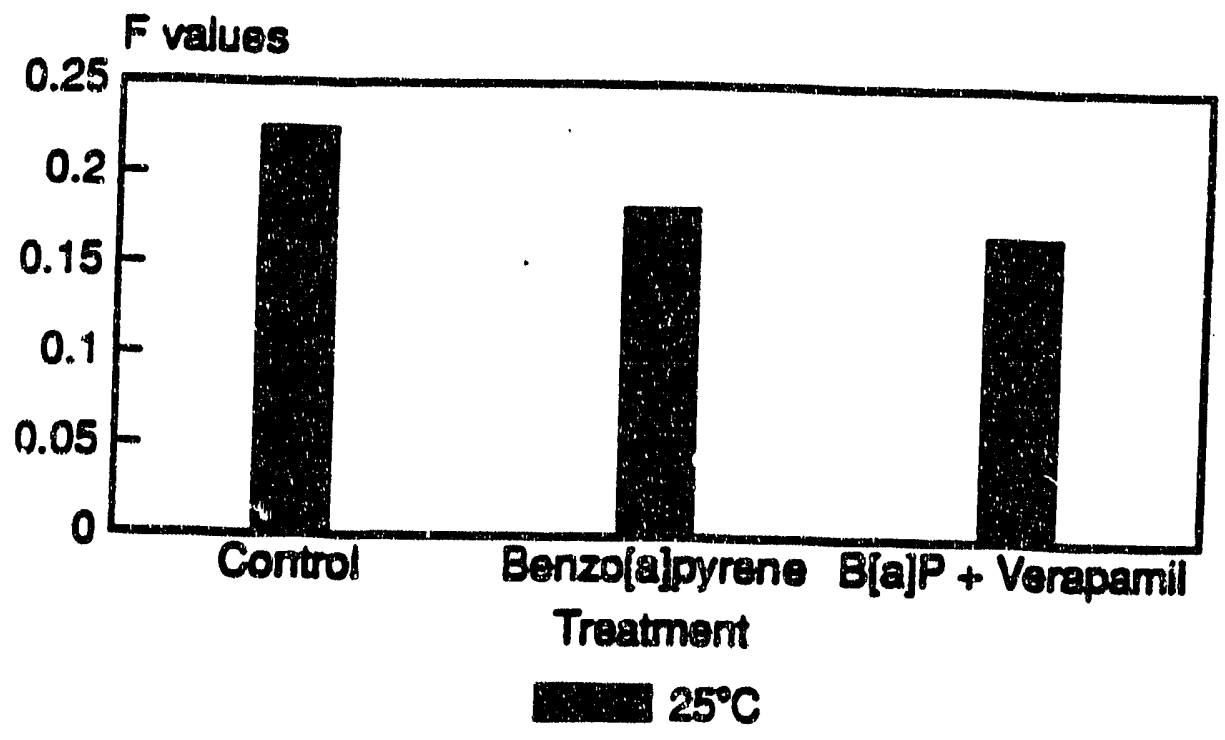

Figure III.10 values of medala DNA after exposure to BaP at a constant concentration of $4 \mu \mathrm{g} / \mathrm{L}$ for 10 days. DNA was purified by a modified procedure which extensively deproteinated the DNA during purification. 


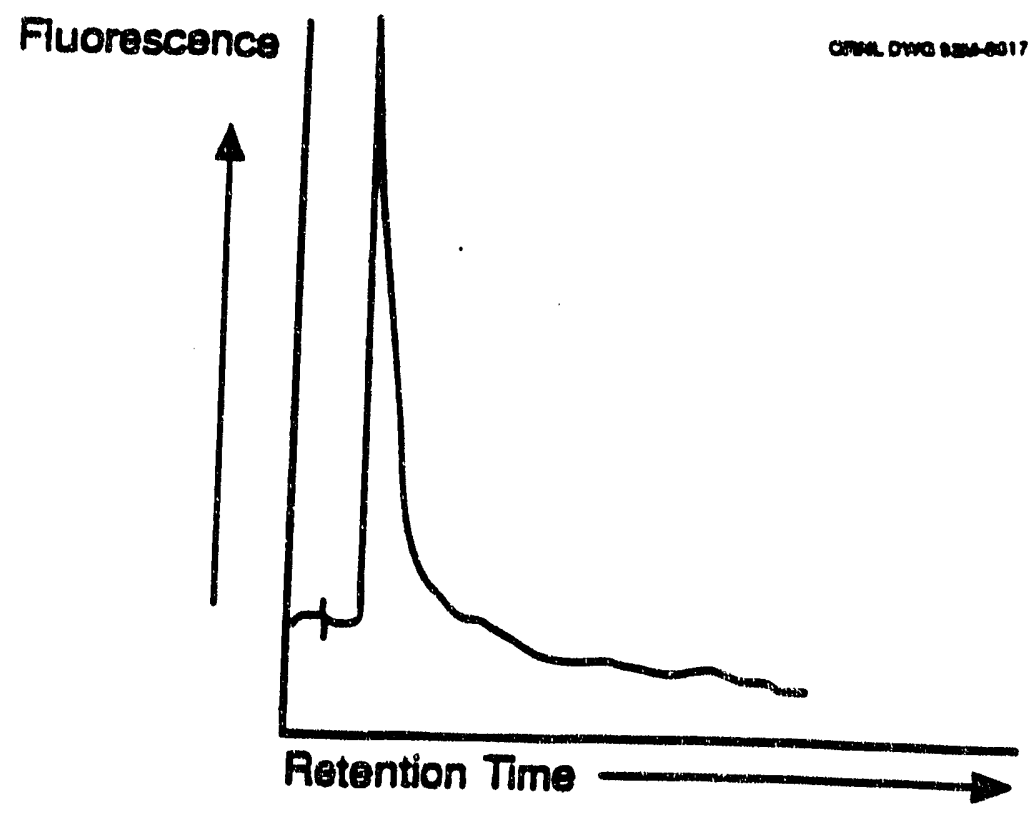

Figure III. 11 BaP-tetrol adducts in medala DNA exposed to BaP for 10 days at a constant concentration of $4 \mu \mathrm{g} / \mathrm{L}$. Adducts were determined by HPLC fluorescence analysis of tetrols liberated from [NA by acid hydrolysis.

\section{c. BaP Exposure IV}

A comparison of chromosomal proteins extracted from precipitated chromatin from erythrocyte nuclei, according to a procedure adapted from Miller (1988), for bluegill, medaka, and SId BaP exposed medaln is shown in Fig. III.12. Both the core and H1-HS histone profiles are very similar for control bluegill (Fig. III.12A) and medaka (Fig. III. 12B) with medain H1-H5 histone groups showing a slightly greater electrophoretic mobility than the bluegill H1-HS histone group. The HS histone is found in the nucleated erythrocytes of both birds and fish, but is absent in other tissues of these animals. There is a greater amount and variecy of non-histone proteins present in medalon chromatin relative to bluegill. These proteins are predominately much higher in molecular weight than the histone groups and have a regulatory function on DNA. In medaka exposed to Bap for 51d (Fig. III. 12C) there is a loss of most of the non-histone proteins, changes in bistone profiles, and an increase in a protein(s) with an apparent mass of around 14-15 kD. The H1-HS histone 


\section{SDS GEL ELECTROPHORESIS SCANNING DENSITOMETRY}

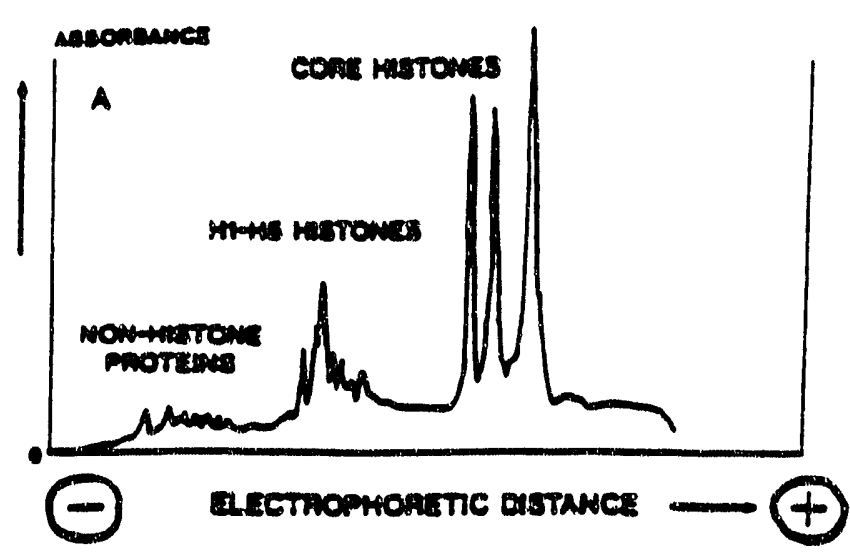

SDS GEL ELECTROPHORESIS SCANNING DENSITOMETRY
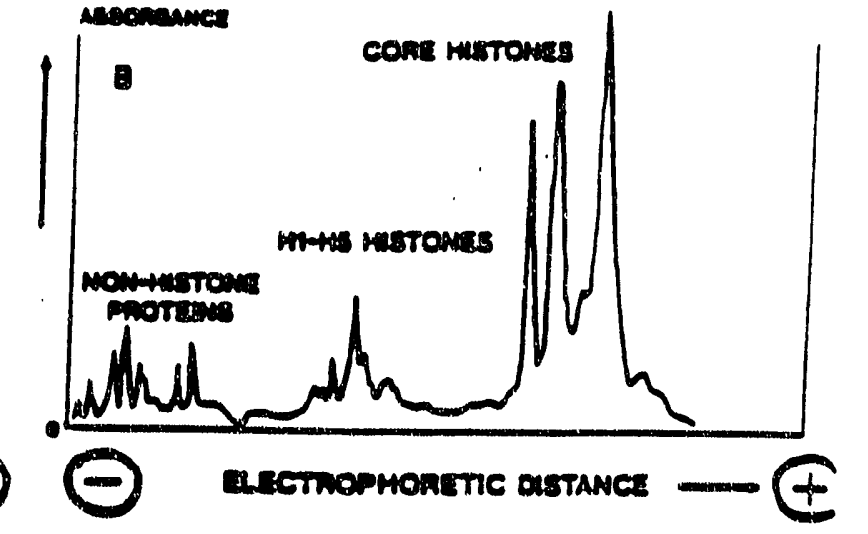

\section{SDS GEL ELECTROPHORESIS SCANNING DENSITOMETAY}

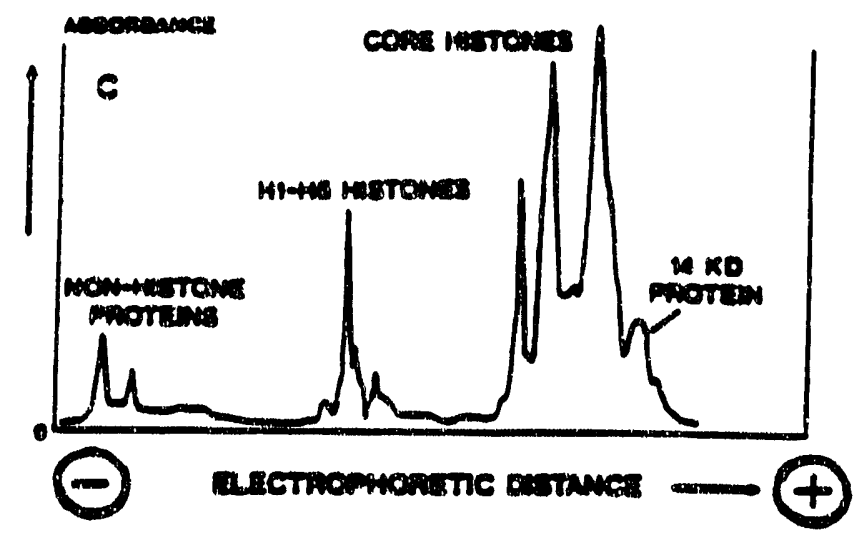

Figure III.12 Scanning densitometric profiles of completely dissociated bluegill and medaka chromosomal proteins. Blood cell nuclei were purified, lysed, and the chromatin was precipitated in ethanol. Protein were dissociated from DNA by boiling in full strength SDS-beta-mercaptoethanol sample solution. PRoteins were analyzed on 13\% SDS-PAGE gels and stained with Coomassie blue.
A. Bluegill control.
B. Medak control
C. Medaka- Exposed to Bap for 51 days 
group shows a wide variable response in BaP exposed fish with enhancement or loss of the prominent peak in that group. In the core histone group the protein peak with the least mobility (more + charged protein band) is consistently reduced relative to the other core histone bands in BaP exposed fish.

A comparison of nuclear (chromosomal) proteins extracted from bluegill, medaka, and BaP exposed medaka blood cells under partial dissociating conditions is shown in Fig. III.13. The H1-H5 histone group does not dissociate as readily from the DNA as the core histones. The core histones of bluegill (Fig. III.13A) are extracted from DNA more easily than from both control and BaP exposed medaka DNA (Fig. III.13B). Protein(s) with an apparent mass of $14-15 \mathrm{kD}$ is detected in greater amounts in BaP exposed medaka nuclei.

\section{Discussion}

Japanese Medaka were exposed to water in which ${ }^{12} \mathrm{C} \cdot \mathrm{BaP}$ dispersal was facilitated by the presence of a detergent (Tween 80)(BaP exposure I- BaP uptake and reproduction study). Since the maximal solubility of $\mathrm{BaP}$ in water without detergent is about $4 \mu \mathrm{g} / \mathrm{L}$, the presence of Tween 80 could promote temporarily higher concentrations of $\mathrm{BaP}$ in water, but this $\mathrm{BaP}$ may not have been available to the fish. The rapid decline in BaP levels seen in Fig. 1 could be attributed to either uptake into the medaka, metabolism, binding to particulate organic matter and/or absorption to glass and plastic in the aquaria (which is characteristic of hydrophobic polyaromatic hydrocarbons).

During the time that BaP levels decreased during the exposure, there was a rise in BaP levels in the tissues of the medaka. The increase is more rapid during the first day of exposure and changes to a slower but steady rate of accumulation on subsequent days (Fig. III.2). The total amount of BaP accumulation in the 25 fish was less than $150 \mathrm{ng}$ as compared with a decrease in BaP concentrations in water of greater than $30 \mu g$; thus most of the BaP may have been absorbed to other materials in the aquaria, subjected to photodegradation and metabolised in fish tissues. Though a BaP tank containing no fish was included, studies on BaP absorption to organic and inorganic materials in tanks should be performed to settle this question. Female medaka also appeared to accumulate BaP at a 


\section{SDS GEL ELECTROPHORESIS SCANNING DENSITOMETRY}

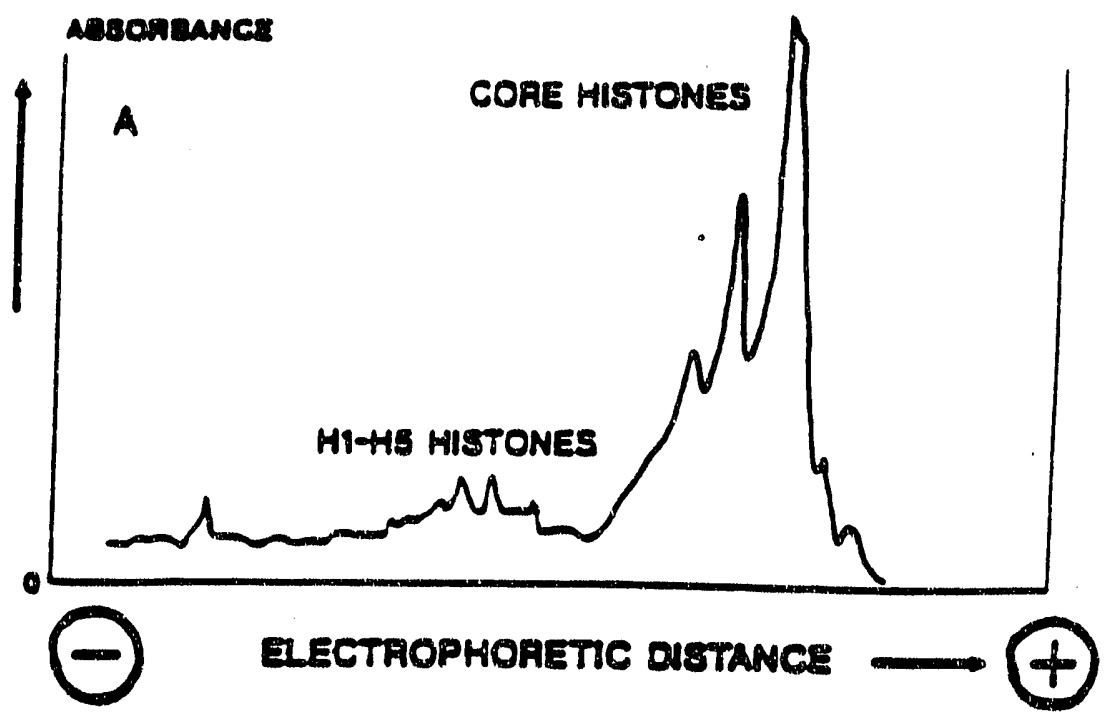

\section{SDS GEL ELECTROPHORESIS} SCANNING DENSITOMETRY

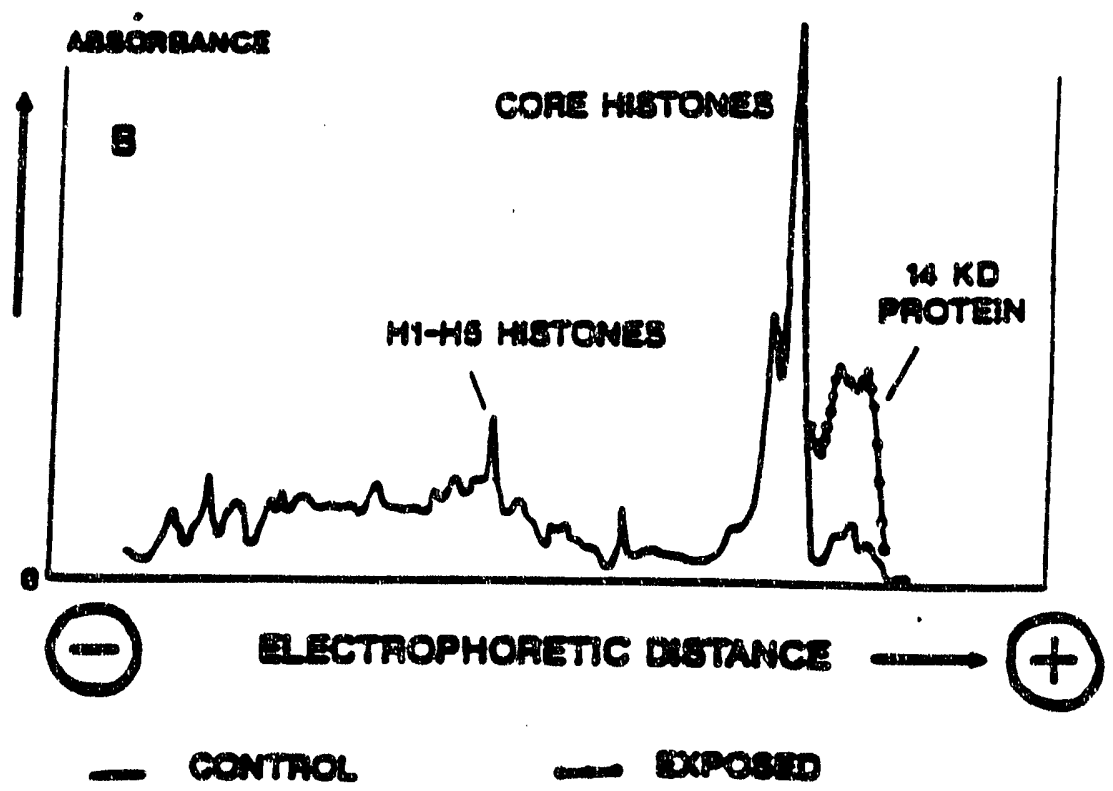

Figure II.13 Scanning densisometric profiles of partially dissociare bluegill and medak nuclear proteins. Blood cell nuclei were purified and lysed. The lysare was made up to IM NaCl, mixed with an equal volume of SDS-beta

mercaptoethenol sample solution, and boiled. Proceins were analyzed on 13\% SDS-PAGE gels and silver strined.

A. Bivezill control

B. Miedak control and exposed to Bap for 51 days 
higher level in their tissues than male fish. However, we do not yet know whether this is a result of metabolic or tissue specific differences between male and female medaka.

Medaka eggs were exposed to BaP only briefly ( $1 \mathrm{~h}$ after spawning). The reproductive parameters only indicate possible trends and were not statistically significant using Student's " $t$ " Test and should be re-evaluated with more formal experimentation. This exposure did not result in significant changes in the numbers of developmental abnormalities or in the morphology of fertilized eggs. The study of fecundity and ovarian oocyte atresia for BaP-treated fish did not indicate overt ovotoxicity . In medaka, BaP is hypothesized to stimulated oocyte development and egg production possibly via an estrogenic effect on the ovaries, BaP might inhibit ovarian function at higher effective concentrations. The lack of ovotoxicity in exposure I may have been caused by the medaka detoxifying and excreting $\mathrm{BaP}$ at the levels present in the water, or perhaps BaP was not biologically available to reproductive tissues in concentrations sufficient to greatly effect reproduction and development. Tween 80 alone may have exhibited some deleterious effect on fecundity, although this effect was not seen in combination with BaP.

The high variability in survival of embryos derived from BaP exposed parents may have resulted from problems with glass pipette transfer techniques. Improved handling tochniques for embryo transfer have been developed which should minimize damage to developing fish. Future, formal studies will additionally focus on genotoxic and teratogenic effects of BaP exposure in medaka and improvements in experimental design and statistical analysis. The dorninant lethal assay has potential to be developed as a measure of genotoxicity in medaka; mice have been successfully tested for dominant lethality following exposure to a large number of xenobiotic compounds (Bateman and Epstein, 1971). Previous studies using intraperitonedl injection of mitomycin $\mathrm{C}$ and ethyl methanesulfonate into medaka have demonstrated a considerable dominant lethal effect as measured by hatchability of fertilized eggs (Shimada and Egami, 1984). The medaka is currently being used for studies of teratogenesis by exposing developing fertile eggs to xenobiotic compounds (Cameron et al., 1985; Shi and Faustman, 1989). Fertilized medaka eggs can be easily monitored through a compound microscope during development. Future studies incorporating the dominant lethal assay, teratogenic analysis, and reproductive studies could 
help identify more specific genotoxic and cytotoxic effects. These studies would formally expand upon the preliminary experiments described in this report in which parental medaka were exposed to BaP and the reproductive and developmental effects analysed. Alkaline unwinding analysis of liver DNA indicated that BaP may not have caused strand breaks in the medaka from BaP exposure I (Fig. III.4). Flow cytometric analyses of liver and gill cells (which provides an estimate of the DNA content of cell nuclei) failed to detect an effect of BaP on nuclear DNA (data not shown).

Tween 80 was not used as a vehicle for dispersing $\mathrm{BaP}$ in the water in experiments II, III, and IV. The water in the second exposure was saturated with BaP at day 0 and was not renewed thereafter. The initial concentration of BaP was initially high but rapidly declined to undetectable levels in the water by day 7; the initial BaP water was prepared by passage through a generator column of BaP coated glass beads (Shugart et al., 1987). The heart drug Verapamil, which inhibits the p-170 glycoprotein xenobiotic pump (Kurelec and Pivcevic, 1989), was renewed daily $(1 \mu \mathrm{g} / \mathrm{L})$ in the verapamil and BaP + verapamil treatments.

The alkaline unwinding rates obtained from DNA extracted from whole fish in BaP exposure II, in which medaka were chronically exposed to $4 \mu \mathrm{g} / \mathrm{L} \mathrm{BaP}$ (starting with BaP saturated water on day one with no further water changes or additions) for 7 days (Figs. III.5 and III.6), showed that medaka DNA was very resisant to unwinding at incubation temperatures successfully used to measure DNA strand breaks in BaP exposed Bluegill sunfish and in other animal species. We found no significant difference in the DNA strand breakage of fish treated with BaP alone or those treated with verapamil. Also, resistance of medaka DNA to alkaline unwinding was greater for fish exposed to BaP, verapamil, and BaP + verapamil than it was for unexposed control fish (Fig. III.7). Thus, high concentrations of salt ( $>250 \mathrm{mM} \mathrm{NaCl}$ ) and/or proteinase $\mathrm{K}$ digestion during DNA extraction may have removed an unidentified proteinaceous unwinding inhibitor that, 1) associates with medaka DNA and 2) is induced by exposure of the fish to xenobiotic compounds.

Several hypotheses for the resistance of medaka to DNA damage from xenobiotic compounds can be formulated: 1) these fish have efficient metabolism and excretion of BaP from the gills; 2) medaka may be able to induce or increase the activity of a xenobiotic pump (the use of higher concentrations of verapamil or vanadate may effectively inhibit the p-170 
glycoprotein pump and permit toxicants to enter the cells at a higher rate); and 3) an as yet unidentified factor naturally associated with medaka DNA and induced to higher levels by exposure to xenobiotics may protect DNA from damage or facilitate its repair.

The data from Exposure III in which adult medaka were chronically exposed to water saturated with $4 \mu \mathrm{g} / \mathrm{L} \mathrm{BaP}$ for 10 days shows that adducts are detectable after 42 hour exposure, but are not detectable after 10 days (Figs. III.9 and III.11). In contrast, strand breaks are not detectable after 42 hours, but do appear' in a 10 day exposure (Figs. III. 8 and III.10). It should be noted that the increase in strand breaks is approximately 15-20\%, whereas in similar studies conducted on Bluegill, strand breaks increased by as much as $300 \%$ (Shugart, 1988). The factors causing a disappearance of adducts between these two time points concurrent with a rise in strand breaks are not conclusively known. However, this could be explained by a model based on the excision-repair mechanism for repair of damaged DNA (Hanawalt et al., 1979). In this model, adducts are repaired by a mechanism which temporarily creates strand breaks. An endonuclease nicks the DNA strand near the damaged site (adducts, dimers), a DNA polymerase synthesizes new DNA in place of the damaged portion and also excises the damaged portion from the remaining attached end simultaneously, and ligase finally seals the newly-repaired DNA. This model is only one of several known mechanisms of DNA repair, and is one possible explanation for the data. An additional theory is that instead of or in concert with DNA repair, a proteinase $\mathrm{K}$ sensitive protective mechanism is being induced which serves to shield the DNA from damage or maintain DNA structure. This could also account for the relatively small increase in strand breakage compared to similar studies in Bluegill. The high incidence of strand breaks in Bluegill may result from a greater initial sensitivity to DNA damaging agents but a decrease in strand breaks during chronic BaP exposure may result from induced repair processes (Shugart, 1988).

Fig. III.12 shows that, under strong dissociating conditions, medaka blood cell chromatin contains relatively more non-histone proteins than bluegill. Non-histone proteins comprise around $40 \%$ of the chromosomal protein in most cells (Van Holde, 1989), except nucleated erythrocytes where histone comprise over $80 \%$ of chromosomal protein. Nonhistone proteins contain more than 100 different proteins each in low abundance relative to 
the 5-6 main histone types which are abundant in eukaryotic cells. The loss of non-histone proteins in 51d BaP exposed medaka may reflect an overall decrease in DNA regulatory/gene expression activity in chronic exposed fish.

Current studies in our lab exposing bluegill to heavy metal $(\mathrm{Pb}, \mathrm{Hg})$ and PAH contaminated sediment has shown a considerable increase in non-histone proteins at two weeks exposure and a near complete loss of these proteins at eight weeks exposure (unpublished observations). Many organ-tissue cells are in a constant state of differentiation and regeneration such as blood and liver tissue and changes in non-histone proteins may signal subsequent changes in the state of differentiation. These cellular changes are known to occur in pathological conditions (cancer, anemias, etc.). Additionally, changes in nonhistone protein composition may follow the induction of the various enzymes responsible for DNA repair functions.

Histones comprise most of the chromosomal protein in eukayotic cells (Van Holde, 1989). The nucleosomal core structures contain two each of $\mathrm{H} 2 \mathrm{~A}, \mathrm{H} 2 \mathrm{~B}, \mathrm{H} 3$ and $\mathrm{H} 4$ histones common to all eukayotic cells while $\mathrm{H} 1$ histone serves to bind adjacent nucleosomes together to facilitate higher orders of chromosomal folding. Erythrocyte nuclei of birds reptiles and fish contain an additional H5 histone whose concentration increases with red cell differentiation. The H1-(H5) histones are quite variable between and within species as well as in different tissues. The different electrophoretic mobility between bluegill and medaka H1-H5 histone groups denote different functional variants within this group. Changes in the quantitative profiles seen in BaP exposed fish may reflect a change in chromatin structure and cell differentiation.

Differences in the core histones between bluegill and control-exposed medaka under conditions of differential protein extraction (Fig. III.13) indicate a nucleosomal structure more resistent to dissociation in medaka relative to bluegill. The protein(s) of apparent molecular weight 14-15 kD which is induced and easily extracted from BaP exposed medaka may be modified histone or represent new protein synthesis.

While these histones are highly evolutionarily conserved, they are known to possess modifications which can affect structure, function, and electrophoretic mobility (Van Holde, 1989). This is primarily because modifications, such as phosphorylation, acetylation, and 
poly-ADP-ribosylation decrease the positive charge of the histone, and serve to increase gel mobility. Poly-ADP-ribosylation of histone (Van Holde, 1989) is a possible explanation of resistance of nucleosomes to dissociation. Nucleosome binding by this polymer could confer some degree of resistance to protease treatment. Another modification that could be important is histone phosphorylation, which may be associated with a tightening of chromatin structure (Van Holde, 1989). The increased migration distance associated with the negative charge on the phosphate group could change the histone densitometric profile.

It is clear that considerably more data need to be amassed before any conclusions concerning the phenomenon of observed resistance to unwinding in medaka DNA can be drawn. This work provides some basis for future study. It is apparent that there are differences in the protein content of chromatin, both between Bluegill and medaka, and between control and BaP exposed medaka. These differences may function to protect DNA and/or to be responsible for resistance to unwinding in medaka. Future studies could involve isolation and characterization of particular protein fractions, with the intent of identifying factors involved in DNA protection and resistance to unwinding. Experimentally, fractions could be tested for ability to bind to DNA, which may give some indication as to capacity to confer resistance to deproteination. Also, future studies could focus more extensively on the phenomenon of Histone modification. Poly-ADP-ribosylation and phosphorylation can be quantified in histone fractions. Employing 2D gel electrophoresis and western blot analysis with antibody probes can identify specific protein species which maintain DNA structure such as repair enzymes.

\section{References}

Ausubel, F.M., R. Brent, R.E. Kingston, D.D. Moore, J.G. Seidman, J.A. Smith, and K. Struhl. (1989). Current Protocols in Molecular Biology. John Wiley and Sons, New York, NY.

Bachrach, U. (1973). Eunction of Naturally Occurring Polyamines. Academic Press, New York. 
Bateman, A.J. and Epstein, S.S. (1971). Dominant lethal mutations in mammais. In Hollaender (Ed.) Chemical Mutagens. Principles and Methods for their Detection, Plenum Press, New York, NY, vol 2:541-563.

Cameron, I.L., Lawrence, W.C. and Lum, J.B. (1985). Medaka eggs as a model system for screening potential teratogens. In, Prevention of Physical. Mental and Congenital Defects. Part $C_{i}$ Basic and Medical Science, Education and Future Strategies. Alan R. Liss Inc., New York NY; pp 239-251.

Donaldson, E.M., and E. Scherer. (1983). Methods to test and assess effects of chemicals on reproduction in fish. In Vouk and Sheehan (eds.) Methods of Assessing the Effects of Chemicals on Reproductive Functions. Wiley, New York.

Greeley, M.S. Jr., Calder, D.R. and Wallace, R.A. (1987). Oocyte growth and development in the striped mullet, Mugilcephalus, during seasonal ovarian recrudescence: Relationship to fecundity and size at maturity. Eishery Bull. 85:187200.

Hanawalt, P.C., Cooper, P.K., Ganesen, A.K. and Smith, C.A. (1979). DNA repair in bacteria and mammalian cells. Ann, Rev. Biochem. 48:783-836.

Hawkins, W.E., Overstreet, R.M. and Walker, W.W. (1988). Carcinogenicity tests with small fish species. Aquatic Toxicology 11:113-128.

Hewish, D.R., and L.A. Burgoyne. (1973). Chromatin Sub-structure. The digestion of chromatin DNA at regularly spaced sites by a nuclear deoxyribonuclease. Biochemi. Biophys. Res. Commun. 52:504-510.

Hoel, D., N. Kaplan and M. Anderson. (1983). Implication of nonlinear kinetics on risk estimation in carcinogenesis. Science. 219:1032-1037.

Ishikawa, T., Shimamine, T. and Takayama, S. (1975). Histological and electron microscopy observations on diethylnitrosamine induced hepatomas in small aquarium fish (Oryzias latipes). I Natl. Cancer Inst. 55:909-916.

Kennedy, C.J., Gill, K.A. and Walsh, P.J. (1989). Thermal modulation of benzo[a]pyrene uptake in the gulf toadfish, Opsanus beta. Enviom. Tox. Chem. 8:863-869.

Kirchen, R.V. and West, W.R. (1976). The Japanese Medaka, Its care and development. Carolina Biological Co; Burlington, NC, pp 1-36.

Kurelec, B. and Pivcevic, B. (1989). Distinct glutathione-dependent enzyme activities and a verapamil sensitive binding of xenobiotics in a fresh water mussel Anodonsa cynnea. Biochem. Biophys, Res, Comm. 163:934-940. 
Laemmli, U.K. (1970). Cleavage of structural proteins during the assembly of the head of bacteriophage T4. Nature (London) 227:680-685.

Lin, Y-W.P., Greeley, M.S.Jr. and Wallace, R.A. (1989). Fundulis heteroclitus gonadotropins 2. Year round husbandry of animals with active pituitaries and responsive follicles. Fish Physiol. Biochem. 6:139-148.

Maniatis, T., Fritsch, E.F. and Sambrook, J. (1982). Molecular Cloning: A Laboratory Manual. Cold Spring Harbor Laboratory, Cold Spring Harbor, Box 100, New York.

Miller, S. (1988). Isolation and characterization of chromosomal proteins from the mosquito (Anopheles albimanus) Weidemann. Int. J. Biochem. 20:1247-1253.

Oakley, B.R., D.R. Kirsch, and N.R. Morris. (1980). A simplified ultrasensitive silver stain for detecting proteins in polyacrylamide gels. Analytical Biochemistry 105:361-363.

Phillips, D. and P. Sims. (1979). PAH metabolites: their reaction with nucleic acids. In: Chemical Carcinogens and DNA, Vol. 2, edited by P.L. Grover, CRC Press, Inc., Boca Raton, FL, pp. 9-57.

Shimada, A. and Egami, N. (1984). Dominant lethal mutations induced by MMS and mitomycin C in the fish Oryzias latipes. Mutation Research 125:221-227.

Shi, M. and Faustman E.M. (1989). Development and characterization of a morphological scoring system for medaka (Oryzias latipes) embryo culture. Aquatic Toxicol. $15: 127$.

Shiu, W.Y., Maijanen, A., Anita, L.Y. Ng. and Mackay, D. (1988). Preparation of aqueous solutions of sparingly soluble organic substances: II. Multicomponent systems-hydrocarton mixtures and petroleum products. Enviom. Tox. Chem. 7:125137.

Shugart, L.R., McCarthy, J.F., Jimenez, B. and Daniels J. (1987). Analysis of adduct formation in the Bluegill Sunfish Lepomis macrochirus between benzo[a]pyrene and DNA of the liver and hernoglobin of the erythrocyte. Aquatic Toxicology 9:319-325.

Shugart, L.R. (1988). Quantitation of chemically induced damage to DNA of aquatic organisms by alkaline unwinding assay. Aquatic Toxicology 13:43-52.

Taningher, M., Saccomanno, G., Santo, L., Grilli, S. and Parodi, S. (1990). Quantitative predictability of carcinogenicity of the covalent binding index of chemicals to DNA: Comparison of the In vitro and In vive assays. Enviommental Health Perspectives 84:183-192. 
Van Holde, K.E. (1989). Chromatin. Springer-Verlag, New York, NY.

Varanasi, U., J.E. Stein, M. Nishimoto and T. Hom. (1983). BaP metabolites in liver, muscles, gonads and bile of adult English sole (Parophrys vetulus). In: PAHs 7th International Symposium on Formation. Metabolism and Measurement, edited by $M$. Cooke and A.J. Dennis, Battelle Press, Columbus, OH, pp. 1221-1234.

\section{JAPANESE MEDAKA EMBRYO ASSAY FOR DEVELOPMENTAL TOXICITY: ABNORMALITIES OBSERVED AFTER EXPOSURE TO BENZO[a]PYRENE.}

\section{Summary}

Medaka embryos (Oryzias latipes) were exposed to $10 \mu \mathrm{g} \mathrm{BaP} / \mathrm{L}$ (supersaturated microparticulate suspension) in embryo rearing medium (ERM) from $4 \mathrm{~h}$ post fertilization through yolk sac absorption. One group of embryos underwent complete ERM + BaP change every $48 \mathrm{~h}(48 \mathrm{~h} \mathrm{BaP})$. The second group, the controls, also recieved complete solution exchanges every $48 \mathrm{~h}$, but recieved clean ERM. There 'vere no obviously lethal effects observed in the embryos and fry. BaP-treated embryos had significandy more abnormalities, with $15.0 \% \pm 3.59$ in $48 \mathrm{HBaP}$ embryos and fry. Only $4.55 \% \pm 2.22$ of control embyros were observed with circulatory abnormalities. Developmental abnormalities such as twinning, exophthalmia and altered pigmentation occurred in the exposed groups, but were not observed in the controls. BaP exposed embryos required $48 \mathrm{~h}$ longer for $50 \%$ of the embyros to hatch, and exposed embryos continued to hatch for $192 \mathrm{~h}$ beyond the last successful control hatch. The absence of direct lethal effects was evident in the lack of significant difference in the hatching success, mortality, swimbladder inflation or length of time fry could swim between control and exposed groups.

\section{Introduction}

The Japanese medaka (Oryzias latipes) is a fish which is commonly used for embryo toxicity and developmental tests. Medaka embryo assays have been utilized in a number of 
attempts to determine the toxicity (TLm -mean tolerance limit and $\mathrm{LC}_{50}$-concentration that causes 50\% lethality) and teratogenicity of various xenobiotics. However, there is currently no EPA protocol for the assay and there has been little consistency in its application between labs and researchers. For example, initial exposures of medaka embryos to tested xenobiotics have ranged from 2 hours post fertilization (Solomon and Weis, 1979; Dial, 1978) to organogenesis (Solomon and Faustman, 1987;Waterman, 1939; Shi and Faustman, 1979), and mode of exposure has varied from short-term pulses (Siu-yin Leung and Bulkey, 1979; Hiraoka, et al. 1989; Marty, et al., 1991) to exposure throughout the incubation period (Michibata, et al. 1987; Stoss and Haines, 1979; Schreiweis and Murray, 1976; Heisinger and Green, 1975; Hiraoka and Okuda, 1983).

Currently, this lab is investigating various methods of conduction developmental toxicity tests utilizing the medaka, and it is our goal to develop a standard method for the embryo assay which is not labor intensive and can be easily adapted for various classes of chemicals. Ongoing experiments are designed to determine and contrast the effects of exposure of embryos to xenobiotics at several reproductive and devalopmental levels, including exposure to the parents, at the point of fertilization and during embryogenesis. Data from these experiments will complement existing carcinogenesis and adult toxicity data utilizing the Japanese medaka (Hatanaka et al., 1982; Kyono and Egami, 1977; Hawkins et al., 1988a; Hawkins et al., 1988b; Hawkins et al. , 1985).

BaP has been shown to cause various developmental abnormalities in steelhead trout embryos after $24 \mathrm{~h}$ puise exposure ( 2 and $20 \mu \mathrm{g} / \mathrm{ml}$ in DMSO) at specific developmental stages (Kocan and Landolt, 1984). This study demonstrated that the trout embryos were permeable to BaP, could metabolize the parent compound, and excreted some of the metabolites. Embryos exposed earlier in development were seen to both accumulate more and excreted less $\left[{ }^{14} \mathrm{C}\right] \mathrm{BaP}$. This experiment described teratogenic effects, inciuding cephalic and spinal deformities, ocular abnormalities and fin reductions or eliminations. Others have shown that lesser amounts of $\mathrm{BaP}$ could both reduce the hatching success of sand sole (Psettichthys melanostichus) eggs $(0.10 \mu \mathrm{g} / \mathrm{L})$ and produce developmental abnormalities (Hose, et al., 1982). Kocan and Landolt (1984) observed an extension of the hatching period of the steelhead trout as a result of BaP exposure $(2-20 \mu \mathrm{g} / \mathrm{ml}$ on either day 15 or 25 post 
fertilization). BaP was found to produce similiar effects in Rainbow trout (Hannah et al., 1982), where aqueous doses of $\mathrm{BaP}$ as low as $0.08 \mathrm{ppb}$ in the hatching medium extended the hatching time of the embryos. Such results are not necessarily consistent in all species of fishes. Hose et al.(1982) also reported that the survival of flathead and English sole was unaffected by exposure to BaP. The objective of the work described here was to determine if the polycyclic aromatic hydrocarbon, benzo[a]pyrene (BaP), could cause measurable developmental or lethal effects in medaka embryos exposed from 4 hours post fertilization through the yolk sac absorption stage. Other data on adult medaka BaP exp-sures done in this lab have indicated that this species may have some resistance to BaP (unpublished dicul), thus this experiment will also provide data on the sensitivity to another life-stage of the medaka.

\section{Methods and Materials}

a. Adult Care and Maintenance

Japanese medaka (Oryzias latipes) fry obtained from the Gulf Coast Research Laboratory, Ocean Springs, MS., were raised to adulthood in 100 gal. flow-through aquaria supplied with dechlorinated tap water. The light cycle for breeding was 16 hour light:8 hour dark photoperiod at $25^{\circ} \mathrm{C}$. Medaka were offered Stress Flakes twice daily and $24 \mathrm{~h}$ brine shrimp once daily. Breeding groups of adult medaka (ratio 3 female, to 2 male) were placed in two 10-gal aquaria (Tanks A and B) for an overall density of 5 medaka/gal. These breeding aquaria were supplied with dechlorinated tap water which was purified by passage through an activated carbon filter cartridge, a UV sterilizer and a series of three $25-\mu \mathrm{m}$ filters (Balston 54/50 LP-20 cartidge filters).

\section{b. Egg Collection}

Fertilized eggs were collected beginning $1 \mathrm{~h}$ after the initiation of the light cycle; within about 1 hour post fertilization. Females were removed from each breeding lank with a soft, nylon net. Eggs were gently brushed from the outer abdomen with gloved fingers or blunt forceps and placed into petri dishes containing embryo rearing medium 
(ERM). ERM was modified from Kirchen and West (1976), and contained $1 \mathrm{~g} \mathrm{NaCl}, 30 \mathrm{mg}$ $\mathrm{KCl}, 40 \mathrm{mg} \mathrm{CaCl} 2.2 \mathrm{H}_{2} \mathrm{O}$ and $163 \mathrm{mg} \mathrm{MgSO}_{2} .7 \mathrm{H}_{2} \mathrm{O}$ in $1 \mathrm{~L}$ of distilled Millipore-filtered water. Eggs from Tanks A and B were placed into separate petri dishes with approximately 150 eggs per dish. Eggs remain in clutches of 3-50 eggs, held together by chorionic filaments. Clutch separations and removal of these filaments were done under a binocular dissection microscope using fine-tipped watchmakers forceps. Damaged or unfertilized eggs, and any eggs which were obviously remenants of a previous days spawns, were discarded.

\section{c. Exposure to BaP}

Treatment with BaP was initiated within 3.5 to $4 \mathrm{~h}$ of egg collection. There were two treatment groups: a) controls, which were incubated in ERM alone and received exchanges of aerated ERM every $48 \mathrm{~h}$ until hatch, at which time they received $48 \mathrm{~h}$ exchanges of aerated distilled water and b) $48 \mathrm{~h} \mathrm{BaP}$, which were incubated in ERM + BaP solution and received exchanges of this aerated solution every $48 \mathrm{~h}$ until hatch, at which time they received $48 \mathrm{~h}$ exchanges of the supersaturated BaP solution in distilled Millipore filtered water.

Each egg was placed individually into $7-\mathrm{ml}$ scintillation vials containing $1 \mathrm{~mL}$ of either ERM or ERM + BaP solution. Incubations were carried out at $24.5-25^{\circ} \mathrm{C}$ under low light conditions with the same photoperiod as the adults. Medaka eggs have a clear chorion, making microscopic observation of development easy. Embryos were observed at $24 \mathrm{~h}$ intervals for abnormalities, deaths or hatching. Once hatched, fry were observed daily for survival, swimbladder inflation, development of swimming ability, and post-hatch manifestation of any other obvious developmental abnormalities.

\section{d. Preparation of Exposure Solutions}

ERM-BaP (supersaturated microparticulate suspensions), for exposures were made using BaP coated glass beads. The glass beads, 1-2 mm diameter (10-20) which had been previously coatec with BaP were placed into a glass jar and $-250 \mathrm{~mL}$ of ERM added. The mixture was stirred for $24 \mathrm{~h}$, following which a $10 \mathrm{~mL}$ aliquot was recovered for analysis on HPLC. This procedure was repeated every $48 \mathrm{~h}$. Beads were replaced when 
chemical analysis showed any changes in BaP concentration of the ERM medium. BaP water solutions for fry were also made using glass beads, except Millipore filtered, distilled water was added in place of ERM. All samples for analysis were treated identically to the ERMBaP. Waste ERM-BaP from the incubation vials was periodically saved and pooled in 10 $\mathrm{mL}$ aliquots and saved for HPLC analysis. This was done to determine the amount of BaP remaining in solution at the end of a $48 \mathrm{~h}$ period.

For the analysis, the $10 \mathrm{~mL}$ aliquot was removed from the collection vial and passed over an equilibrated C18 Sep Pac. The collection vial was extracted twice with $2 \mathrm{~mL}$ of 20\% HPLC-grade methanol, which was then passed through the Sep Pac. All BaP was removed from the Sep Pac with $3 \mathrm{~mL}$ of $100 \%$ methanol. This was taken to dryness under air at $85^{\circ} \mathrm{C}$ and resuspended in $100 \mu \mathrm{L}$ of $100 \%$ methanol. The sample was injected onto an HPLC C18 column and eluted isocratically with 100\% methanol. BaP quantities were calculated by comparison of peaks to known standards and found to range from $4 \mu \mathrm{g} / \mathrm{L}$ to 12 $\mu \mathrm{g} / \mathrm{L}$. Supersaturation of water by small BaP precipitated matter could account for these higher levels of $\mathrm{BaP}$ in water above saturation. The presence of microparticulate BaP in a saturated solution needs to be further measured and may have important toxicological implications.

\section{e. Statistics}

Data for mortality and hatching success for Tanks A and B within each treatment group were subjected to Chi-square analysis and pooled for further consideration if no significant differences were found $(P>0.05)$. Pooled treatment groups were then subjected to the same analysis. When two-by-two contingency tables were analyzed, corrections for continuity were included. Standard error for proportion $\left(S_{p}\right)$ was calculated according to the formula $\left(S_{p}=V_{p q} / n-1\right)$, where $p=$ the proportion of the population in that category and $q=1-p(Z a r, 1984)$. 


\section{Results}

a. Abnormalities in embryo and fry

The $48 \mathrm{~h}$ BaP group showed significantly more developmental abnormalities during embryogenesis than the control group $\left(\mathrm{X}^{2}=3.942\right)$. The most commonly observed abnormalities were pooling of the blood along the veins of the yolk sac and within the developing embryo. Pooling generally occurred in the fore- and hindbrain and in the tail region. Pooling in the brain was most obvious at 7-8 days post fertilization; thereafter, increased pigmentation made continued observation difficult beyond this period. Incidence of circulatory problems is reported in Table IV.1.

TABLE IV.1

Hatching success and mortality in the two groups of embryos.

\begin{tabular}{|c|c|c|}
\hline & Control & $48 \mathrm{~h} \mathrm{BaP}$ \\
\hline $\mathbf{N}=$ & 88 & 100 \\
\hline Percent embryo mortality & $5.68 \pm 2.49^{n}$ & $15.0 \pm 3.59^{b}$ \\
\hline Percent embryo hatch & $94.32 \pm 2.48$ & $85.0 \pm 3.59$ \\
\hline $\begin{array}{l}\text { Percent fry that failed to inflate swimbladder } \\
\text { within } 48-h \text { post hatch }\end{array}$ & $2.41 \pm 1.69$ & $3.7 \pm 2.11$ \\
\hline $\begin{array}{l}\text { Percent embryos and fry with circulatory } \\
\text { abnormalities }\end{array}$ & $4.5 \pm 2.22$ & $15.0 \pm 3.59^{\circ}$ \\
\hline
\end{tabular}

- Percentage \pm the standard error of the proportion.

b 2 embryo failed to hatch by 27 days post fertilization.

c Significantly different from controls, $X^{2}=3.945,0.025<P<0.05$.

Fourteen percent of the embryos in the BaP-treated group exhibited circulatory abnormalities; several embryos had multiple abnormalities. For example, one embryo out of 98 had a large mass of tissue within the yolk sac adjacent to the abdomen. The mass was 
gray and opaque in coloration. The embryo failed to hatch and was observed dead within the chorion 19 days post fertilization.

Although not quantitated, it was observed that many of the BaP exposed embryos and fry had the previously mentioned yellow-green coloration along the dorsal surface and around the outer edges of the mouth. The altered coloration was easily distinguished from the golden-brown coloration of the controls. These embryos did hatch and suffered no apparent problems through yolk sac absorption.

No abnormalities, other than previously mentioned circulatory problems, were observed in the control embryos and fry.

b. Mortality and hatching success and swimbladder inflation

No significant differences were seen in the percent mortality of the two groups of embryos $\left(X^{2}=3.4140\right)$ or in the ability of the fry to inflate their swimbladders $\left(X^{2}=\right.$ 0.000 )(Table IV.1). All control embryos that survived to 12 days postfertilization hatched successfully; whereas the $48 \mathrm{~h} \mathrm{BaP}$ group contained embryos which failed to hatch within 35 days hours postfertilization. Unhatched embryos were pooled with mortalities for statistical purposes (Table IV.1). There were distinct differences in the time-to-hatch for the various treatment groups. BaP exposed embryos did not complete hatching during the time period required for the controls (Fig. IV.1). BaP exposed embryos continued to hatch for $192 \mathrm{~h}$ after the last control embryo had successfully hatched. Control embryos hatched in $46.5 \%$ of the time required for the exposed embryos. This left $13.3 \%$ of $48 \mathrm{~h} \mathrm{BaP}$ embryos still unhatched when all control embryos had completed hatching. Another way to express timeto-hatch is the time at which 50\% of the eggs have hatched (Leung and Bulkley, 1979). As seen in Table IV.2, the BaP treatment groups required $48 \mathrm{~h}$ longer for $50 \%$ hatch.

No further abnormalities were observed in the fry and there was no significant difference in the time during which the fry began to actively swim. This parameter was determined by noting the time period during which each fry was observed swimming and the time at which it ceased. Cessation of swimming usually preceeded death by $48-96 \mathrm{~h}$. 


\section{TABLE IV.2}

The at which $50 \%$ of the embryos within each group batched.

\begin{tabular}{lc}
\hline Group & $\mathbf{T}_{\mathbf{s}}$ (h post fertilization) \\
\hline \multirow{2}{*}{ Control } & 288 \\
$48-h$ BaP & 336 \\
& \\
\hline
\end{tabular}

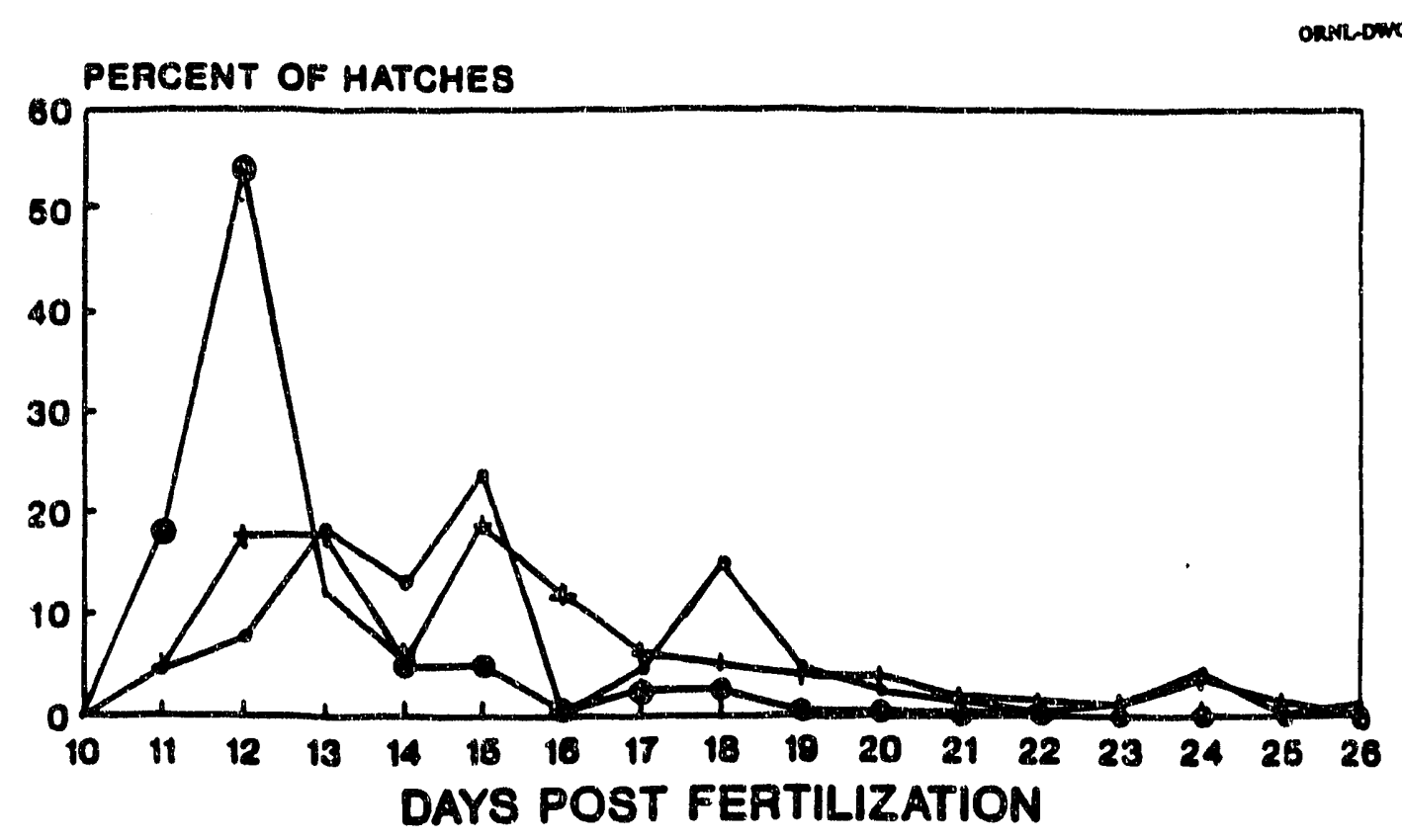

- 24H BaP A + 48 B BAP B - CONTROL A

Figure IV. 1 Embryo hatching. 


\section{Discussion}

The primary goal of this study was to determine if $\mathrm{BaP}$ could produce a measurable developmental effect on medaka embryos when exposure was initiated within $4 \mathrm{~h}$ post fertilization and continued through yolk sac absorption. This time-period for exposure initiation was chosen for its conveinience and reproducibility. Egg collection begins approximately $1 \mathrm{~h}$ after spawning, and clutch separation requires several hours. There is an increased risk of personell exposure if this separation is done in contaminated ERM, however, techniques are being developed to allow earlier exposure-initiation.

Marty, et al., (1990) documented the uptake of labeled BaP into medaka embryos over time. The increased incidence of developmental abnormalities and prevalence of circulatory problems in both BaP exposure groups in the present study provides further evidence that the compound can enter the egg and is adversely affecting development. Further, although hatching success and mortality did not differ significantly from the controls, both exposure groups did exhibit extended hatching times. This corresponds with the data presented in Kocan and Landolt (1984) where the time to hatching for steelhead trout embryos was also extended when exposed to BaP. These researchers theorized that BaP could interfere with the function of hatching enzyme, thereby altering the hatching dynamics of the treated embryos. It has been established that such enzymes exist and control hatching, both in the medaka and in other fish (Blaxter, 1969; Isida, 1944; Yamagami, 1981). Interference with the ability of the enzyme to function would account for both extended time to hatch and failure to hatch. Leung and Bulkey (1979) found that varying concentrations of benzene could alter the ability of medaka eggs to hatch, with premature hatching occurring at lower concentrations and delayed hatching occurring at higher concentrations.

The mortality and hatching success reported in this study agrees with other data reported for BaP exposed embryos, including Hannah, et al. (1982) and Kocan and Landolt (1988). One would expect fry survival time to be altered by the continued exposure to BaP, however, Nebeker, et al. (1974) found that, in the case of one PCB mixture, fry produced by fathead minnow adults aqueously exposed to the commercial PCB Aroclor 1242 during 
spawning and subsequent embryonic development, showed excellent survival if kept at the same concentrations of the PCB as the adults and embryos. This could indicate a resistance developed toward specific compounds or chemical classes which the parents confer on the offspring or which is aquired via exposure during embryonic development. Exposure of fry which undergo embryonic development in control ERM would begin to elucidate the sensitive stage and possibility of resistance.

Additionally, this laboratory is in the process of documenting the effects of different culturing techniques on medaka. Thus far, we have developed the above used technique, which enables us to incubate individual eggs. This aspect has two advantages. First, it allows the observer to follow the progress of individual eggs on a day to day basis, where culturing several eggs in a petri dish or vial does not. Second, it prevents possible interactions between eggs, such as stimulating hatching and, (more importantly in environmental samples) prevents the spread of bacteria or algae between eggs. When environmental water sources are tested, they are sterile filtered, but limited problems still occur with infection in the eggs. Since eggs may contain some microbes from the parents and the water in which they were spawned, it is possible that some water sources are providing nutrients for these endogenous infections. When distilled Millipore filtered water is used, there is no evidence of contamination in the eggs.

Another parameter which has been shown to affect hatching and time to hatch is aeration of the fresh ERM prior to each ERM exchange. Lack of aeration will extend hatching in controls, but not to the extent seen in the BaP exposed embryos.

Further studies will include verification of these results, and exposure during of other reproductive and developmental times, including: 1) fry through yolk sac absorption, 2) gametes during fertilization and 3) parental exposure prior to spawning.

\section{References}

Blaxter. J. H. S. (1969). Development: Eggs and Larvae. In: Fish Physiology. Ed. by W. S. Hoar \& D. J. Randall. Acad. Press, New York, 3:178-252. 
Dial, N. A. 1978. (1978). Methylmercury: some effects on embryogenesis in the Japanese medaka, Oryzias latipes. Teratology. 17 (1):83-92.

Hannah, J. B., J. E. Hose, M. L. Landolt, B. S. Miller. S. P. Felton, and W. T. Owaoka. (1982). Benzo[a]pyrene-induced morphologic and developmental abnormalities in Rainbow trout. Arch. Enbironm. Contam. Toxicol. 11:727-734.

Hatanaka, J., N. Doke, T. Harada, T. Aikawa and M. Enomoto. (1982). Usefulness and rapidity of screening for the toxicity and carcinogenicity of chemicals in the medaka, Oryzias latipes. Japan. J.Exp. Med, 52(5):243-253.

Hawkins, W. E., R. M. Overstreet, J. W. Fournie and W. W. Walker. (1985). Development of aquarium fish models for environmental carcinogenesis: Tumor induction in seven species. L of Applied Toxicol. 5(4):261-264.

Hawkins, W. E., R. M. Overstreet, W.W.Walker. (1988a). Carcinogenicity tests with small fish species. Aquatic Toxicol. 11:113-128.

Hawkins, W. E., W. W. Walker, R. M. Overstreet, T. F. Lytle and J. S. Lytle (1988b). Dose-related carcinogenic effects of water-borne benzo[a]pyrene on livers of two small fish species. Ecotoxicol, and Environm, Safety. 16:219-231.

Heisinger, J. F. and W. Green. (1975). Mercuric chloride uptake by eggs of the ricefish and resulting teratogenic effects. Bull. Environm. Contamin. Toxicol. 14 (6):665-673.

Hiraoka, Y. and H. Okuda. (1983). Characteristics of vertebral abnormalities of medaka as a water pollution indicator. Hiroshima Joumal of Medical Sciences. 32:261-266.

Hiraoka, Y., J. Tanaka and H. Okuda. (1989). Toxicity to medaka of solutions of fentrothion degraded by strong alkali. Environm. Pollution. 58:35-42.

Hose, J. E., J. B. Hannah, D. DiJulio, M. L. Landolt, B. S. Miller, W. T. Iwaoka and S. P. Felton. (1982). Effects of benzo[a]pyrene on early development of flatfish. Arch. Environm. Contam. Toxicol. 11:167-171.

Ishida, J. (1944). Hatching enzyme in the freshwater fish, Oryzias latipes. Annot. Zool. Japon. 22:137-164.

Kirchen, R.V. and W.R. West. (1976). The Japanese medaka; its care and development. Carolina Biological Supply.

Kocan, R.M. and M. L. Landolt. (1984). Alterations in patterns of excretion and other metabolic functions in developing fish embryos exposed to benzo[a]pyrene. Helgoländer Meeresunter. 37:493-504. 
Kyono, Y. and N. Egami. (1977). The effect of temperature during the diethlynitrosamine treatment on liver tumorigenesis in the fish Oryzias latipes. Eur. J Carcinogenesis. 13:1191-1194.

Leung, T. S-y. and R. V. Bulkley. (1979). Effects of petroleum hydrocarbons on length of incubation and hatching success in the Japanese medaka. Bull. Environm. Comtam. Toxicol, 23:236-243.

Marty, G. D., J. Nunez, D. J. Lauren and D. E. Hinton (1990). Age-dependent changes in toxicity of N-nitroso compounds to Japanese medaka (Oryzias latipes) embryos. Aquatic Texicology. 17:45-62.

Michibata, H., Y.Nojima and M. K. Kojima. (1987). Stage sensitivity of eggs of the teleost Oryzias latipes to cadmium exposure. Environm. Res. 42:321-327.

Nebeker, A. V., F. A. Puglisi and D. L. DeFoe. (1974). Effect of polychlorinated biphenyl compounds on survival and reproduction of the fathead minnow and flagfish. Trans. Amer. Fish. Society. 103:562-568.

Schreiweis, D. O. and G. J. Murray. (1976). Cardiovascular malformations in Oryzias latipes embryos treated with 2,4,5-trichlorphenoxyacetic acid (2,4,5-T). Teratology. 14:287-290.

Shi, M. and E. M. Faustman. (1989). Development and characterization of a morphological scoring system for medaka (Oryzias latipes) embryo culture. Aquatic Toxicol. 15:127-140.

Sin-yin Leung, T. and R. V. Bulkey. (1979). Effects of petroleum hydrocarbons on length of incubation and hatching success in the Japanese medaka. Bull. Environm. Contam. Toxicol. 23:236-243.

Solomon, F. P. and E. M. Faustman. (1987). Developmental toxicity of four model alkylating agents on Japanese medaka fish (Oryzias latipes) embryos. Environm. Toxicol and Chem, 6 (10):747-754.

Solomon, H. M. and J. S. Weis. (1979). Abnormal circulatory development in medaka caused by the insecticides carbaryl, malathion and parathion. Teratology, 19 (1):5162.

Stoss, F. W. and T. A. Haines. (1979). The effects of toluene on embryos and fry of the Japanese medaka (Onyzias latipes) with a proposal for rapid determination of maximum acceptable concentration. Environm. Pollut. 20 (2):139-148. 
Waterman, A.J. (1939). Effects of 2,4-dinitrophenol on the early development of the teleost, Oryzias latipes. Biol Bull. 76:162-170.

Yamagami, K. (1981). Mechanisms of hatching in fish: Secretion of hatching enzyme and enzymatic choriolysis. Amer. Zool. 21:459-471.

Zar, J. H. (1984). In: Biostatistical Analysis 2nd Edition. Ed. Prentice-Hall, Inc. Englewood Cliffs, NJ. p. 377.

\section{v. CONCLUSIONS}

Japanese Medaka were exposed via their water to $\mathrm{DEN}$ and $\mathrm{BaP}$ in both continuous and discontinuous exposure protocols. A suite of molecular and cellular biomarkers were assayed on liver, and "whole fish" samples. Biomarker studies concentrated on the effects of DEN and BaP exposure to DNA integrity and detoxication enzymes. Medaka eggs were also exposed to $\mathrm{BaP}$ in water and the teratogenic effects on embryo development and hatching success and survivability were measured.

Studies designed to measure direct DNA damage in exposed medaka showed a differential response to DEN and BaP. Attempts to measure DNA adducts using monoclonal antibodies were unsuccessful for fish exposed to DEN but were detected for BaP by HPLC fluorescence; possibly because the larger BaP derived adducts are not removed by the more efficient enzymatic machinery which directly removes adducts caused by small alkylating agents such as DEN. Adducts derived from BaP may be removed by excision repair mechanisms. Only a low level of DNA strand breaks were detected after DEN exposure I $(200 \mathrm{mg} / \mathrm{L})$ in which fish were exposed in an on-off fashion to four separte 24 hour exposures and after ten days of continuous BaP exposure at $4 \mu \mathrm{g} / \mathrm{L}$ (Part III, BaP exposure III). The DNA strand breaks were only detectable after BaP exposure when the DNA was extensively deproteinated and for DEN, , iuring the recovery period after a short pulse type exposure. Perhaps the most interesting effect on medaka DNA was seen in exposures to BaP at $4 \mu \mathrm{g} / \mathrm{L}$ non renewal in a seven day exposure and in the second DEN exposure (continous 5 week exposure at 25,50 , and $100 \mathrm{mg} / \mathrm{L}$ treatment groups) following alkaline unwinding analysis. Continuous exposure to genotoxic agents causes an increase in apparent DNA 
double strandedness (increase in $F$ values) during exposure. Preliminary studies show that medaka DNA is inherently resistent to unwinding under alkaline conditions; this resistance and the observed increase in $F$ values during genotoxic exposures is relieved upon extensive treatment of DNA with proteinase $K$. This phenomenon has recently been observed in our laboratory in DNA extracted from soybean exposed to enhanced UV-B radiation. Studies are underway to ascertain the nature of this proteinaceous material characteristic to medaka DNA and induced by exposure to DEN and BaP. This phenomenon is clearly a new biomarker of early exposure of medaka to genotoxic compounds, possibly also for toxicants in general and was not previously seen in a number of organisms such as bluegill sunfish, turtles, mice etc. in which DNA strand breaks are readily detected by the alkaline unwinding assay following genotoxicant exposure. In medaka exposed to DEN, there was an inhibition of phase I detoxication enzyme activity and increased phase II activity, observations that are also characteristic of rodents.

Flow cytometric analysis of liver tissue DNA for both DEN and BaP exposed fish did not conclusively show changes in cellular DNA content in liver cells. The most apparent effect of DEN exposure on liver tissue cells was cytocidal in nature. DEN, at the concentrations employed in exposures one and two caused a general cell killing for both exposures evidenced by an increase in cell replication activity. There may have been generation of some cells with altered DNA content after one week of continuous DEN exposure. Because medaka exposed to BaP did not show changes in cellular DNA content, more powerful carcinogens should be tested in this regard.

In medaka exposed to BaP there was an observed increase in fecundity, possibly due to a hormonal-like stimulation of ovarian vitellogenic oocytes resulting in an increase in fecundity. BaP accumulates rapidly fast in medaka tissue followed by a slower rate of increase. Females accumulate BaP at higher concentrations than males probably because the higher fat content in ovarian tissue can accommodate a greater burden of this PAH. No lethal effects were observed in medaka embryos and fry from BaP exposure. Circulatory abnormalities, twinning, exopthalmia, altered pigmentation and delayed hatching are characteristic teratogenic effects in medaka. The sensitivity of medaka embryos to BaP and presumably other organics would make this animal ideal for sublethal teratogenic toxicity 
testing. We are currently engaged in several demonstration projects with this assay on contaminated field sites and the results are very encouraging.

\section{ACKNOWLEDGEMENTS}

The authors gratefully acknowledge the excellent technical assistance of Mr. Doug Jones of the U.S. Army Biomedical Research and Development Laboratory. The Oak Ridge National Laboratory is managed by Martin Marietta Energy Systems Inc., under Contract No. DE-AC05-84OR21400 with the U.S. Department of Energy. This work was supported in part by the U.S. Army Biomedical Research and Development Laboratory (DOE project No. 1016-BO47-A1) and by an appointment to the U.S. Department of Energy Laboratory Cooperative Postgraduate Research Training Program administrated by The Oak Ridge Associated Universities. This is Environmental Sciences Division Publication No. 3550. 


\section{INTERNAL DISTRIBUTION}

1.

2.

3.

4.

5.

6.

7.

8.

9.

10.

11.
L. D. Bates

J. B. Cannon

J. H. Cushman

S. J. D'Sumley

D. E. Fowler

C. W. Gehrs

C. Gettys/Hull

M. S. Greeley

S. G. Hildebrand

P. Kanciruk

A. P. Malinauskas
12.

13.

14.

15.

16.

17. 18-20. 21.

22.

23.

23-36.
D. E. Reichle

F. E. Sharples

D. S. Shriner

L. R. Shugart

S. H. Stow

R. I. Van Hook

Laboratory Records, (ORNL-RC)

Central Research

ORNL. Patent Section

ORNL Y-12 Technical Library

\section{EXTERNAL DISTRIBUTION}

37. J. F. Franklin, Bloedel Professor of Ecosystem Analysis, College of Forest Resources, University of Washington, Anderson Hall (AR-10), Seattle, WA 98195

38. Jay Grimes, Environmental Sciences Division, Office of Health and Environmental Research, Office of Energy Research, ER-74, U. S. Department of Energy, Nashington, DC 20585

39. G. Y. Jordy, Director, Office of Program Analysis, Office of Energy Research, ER-30, G-226, U.S. Department of Energy, Washington, DC 20545

40. R. H. Olsen, Professor, Microbiology and Immunology Departsnent, University of Michigan, Medical Science Building II, No. 5605, 1301 East Catherine Street, Anna Astor, MI 48109-0620

41. F. H. Wobber, Environmental Sciences Divisior, Office of Health and Environmental Research, Office of Energy Rese ch, ER-74, U.S. Department of Energy, Washington, DC 20585

42. A. Patrinos, Acting Director, Environmental Sciences Division, Office of Health and Environmental Research, Office of En rpy Research, ER-74, U.S. Department of Energy, Washingion, DC 20545

43. Ms. Mare Tiemann, Library of Congress CRS/ENR, Rooin 423, First Strteet and Independence Avenue, SE, Washingion, DC 20540 
44-55. Commander, U.S. Army Biomedical Research and Development Laboratory, Attn: SGRD-UBG-E. Fort Detrick, Frederick, Maryland 21701-5010

56-57. Defense Technical Information Center, ATTN: DT C.DDAC, Cameron Station, Alexandria, VA $22304-6145$

58. U.S. Army Medical Research and Development Command, ATTN: SGRD-RMI-S, Fort Detrick, Frederick, Maryland 21702-5012

59. Office of Assistant Manager for Energy Research and Development, U. S. Department of Energy Oak Ridge Field Otfice, P.O. Box 2001, Oak Ridge, TN $37831-8600$

60-70. Office of Scientific and Technical Information, P.O. Box 62, Oak Ridge, TN $37831-8600$ 

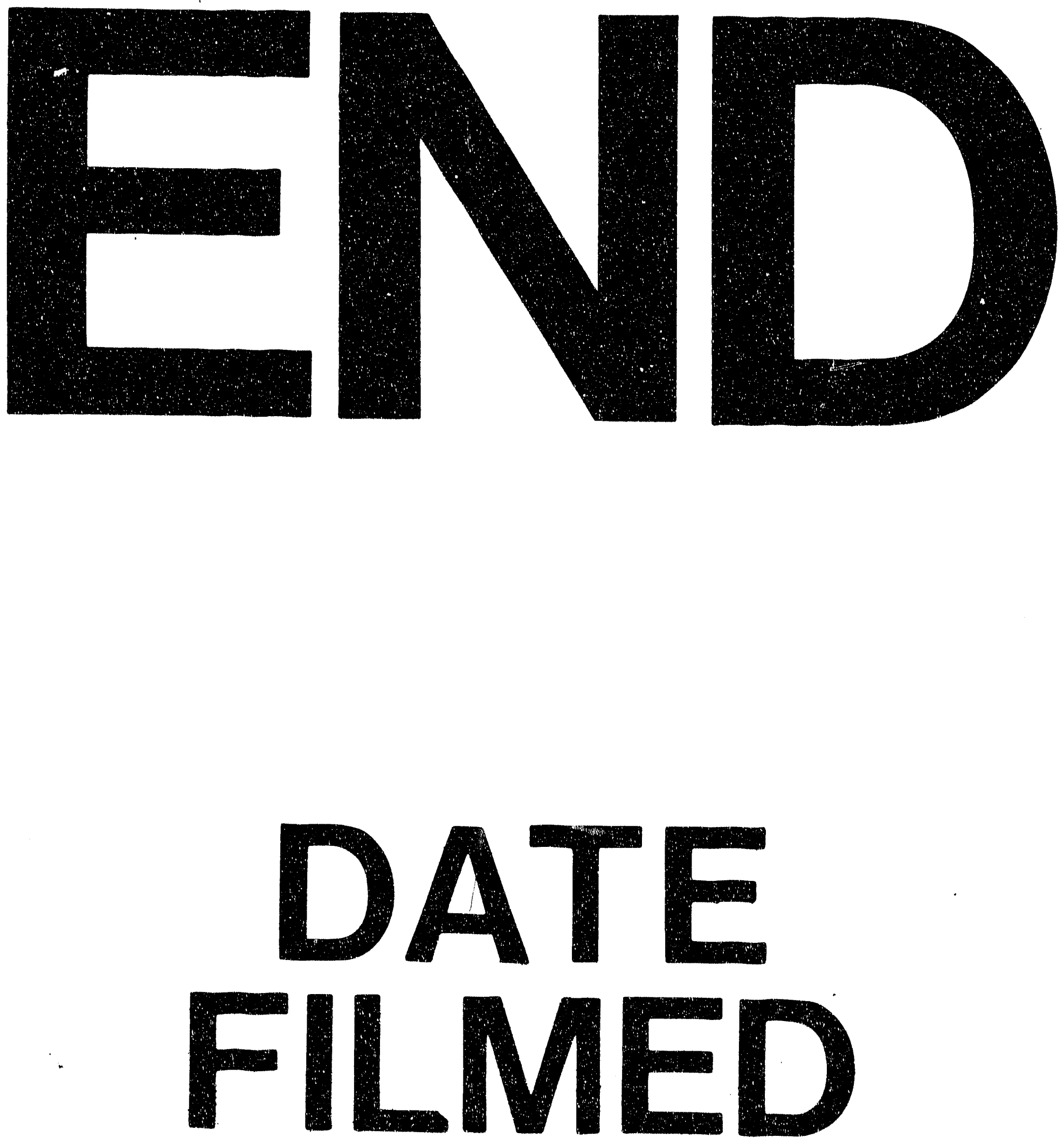

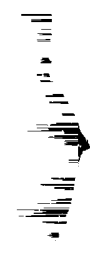

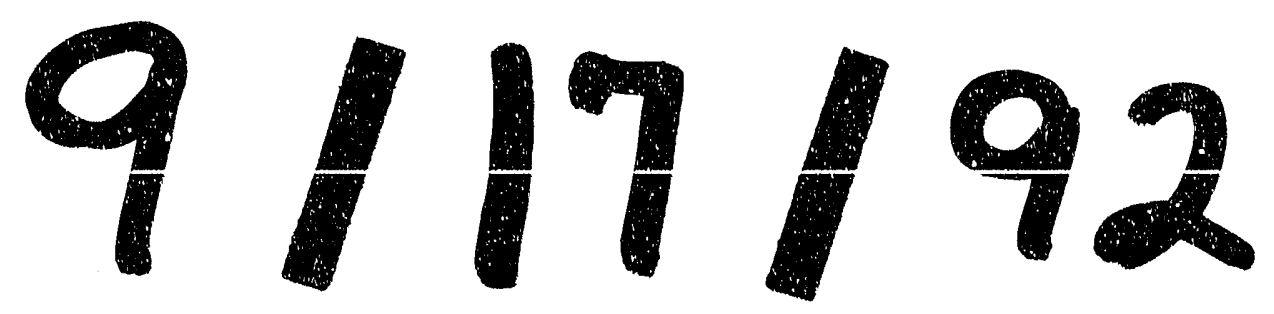


